\title{
\#USGS
}

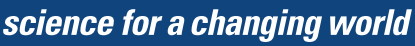

Prepared in cooperation with the Bureau of Reclamation

\section{Hydrogeologic Framework and Occurrence, Movement, and Chemical Characterization of Groundwater in Dixie Valley, West-Central Nevada}

Scientific Investigations Report 2014-5152

U. S. Bepartiment of the Interiot u.s. Gealogiter survey 

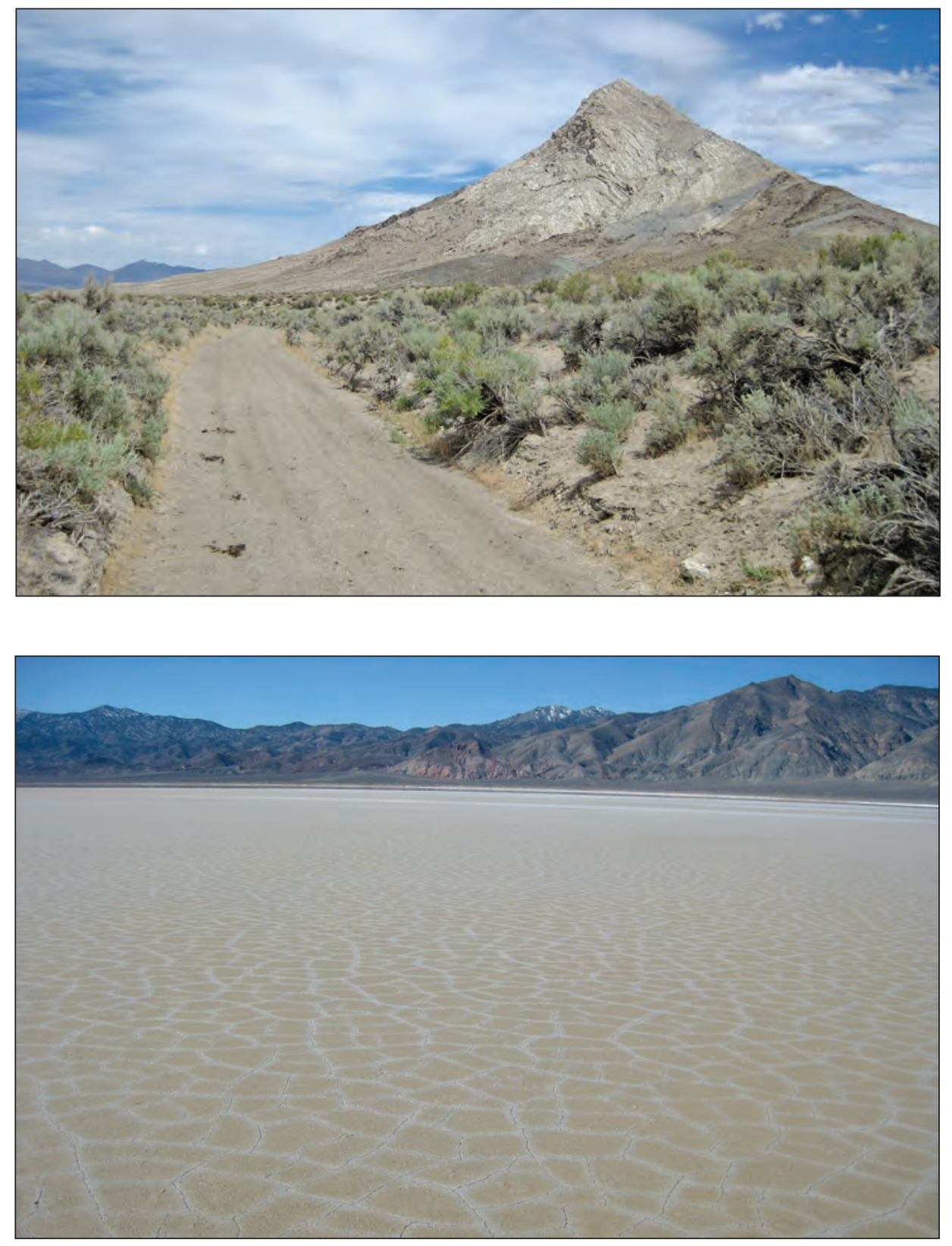

Top: Dixie Valley Wash (dry), near the Stingaree and Dixie Valley border. Pictured looking downstream or to the north toward Dixie Valley with Chalk Mountain to the east. Photograph taken by Jena Huntington, U.S. Geological Survey, July 19, 2012.

Bottom: Dixie Valley playa depicting cracking and surface salts, viewed to the west toward the Stillwater Range. Photograph taken by Jena Huntington, U.S. Geological Survey, February 24, 2009.

Cover: Dixie Valley, as viewed southwest toward Stillwater Range. Dixie Valley Geothermal Plant in distance on left. Photograph taken by C. Amanda Garcia, U.S. Geological Survey, June 16, 2010. 


\section{Hydrogeologic Framework and Occurrence, Movement, and Chemical Characterization of Groundwater in Dixie Valley, West-Central Nevada}

By Jena M. Huntington, C. Amanda Garcia, and Michael R. Rosen

Prepared in cooperation with the Bureau of Reclamation

Scientific Investigations Report 2014-5152 


\title{
U.S. Department of the Interior SALLY JEWELL, Secretary
}

\section{U.S. Geological Survey Suzette M. Kimball, Acting Director}

\author{
U.S. Geological Survey, Reston, Virginia: 2014
}

For more information on the USGS - the Federal source for science about the Earth, its natural and living resources, natural hazards, and the environment, visit http://www.usgs.gov or call 1-888-ASK-USGS.

For an overview of USGS information products, including maps, imagery, and publications, visit http://www.usgs.gov/pubprod

To order this and other USGS information products, visit http://store.usgs.gov

Any use of trade, firm, or product names is for descriptive purposes only and does not imply endorsement by the U.S. Government.

Although this information product, for the most part, is in the public domain, it also may contain copyrighted materials as noted in the text. Permission to reproduce copyrighted items must be secured from the copyright owner.

Suggested citation:

Huntington, J.M., Garcia, C.A., and Rosen, M.R., 2014, Hydrogeologic framework and occurrence, movement, and chemical characterization of groundwater in Dixie Valley, west-central Nevada: U.S. Geological Survey Scientific Investigations Report 2014-5152, 60 p., http://dx.doi.org/10.3133/sir20145152.

ISSN 2328-0328 


\section{Contents}

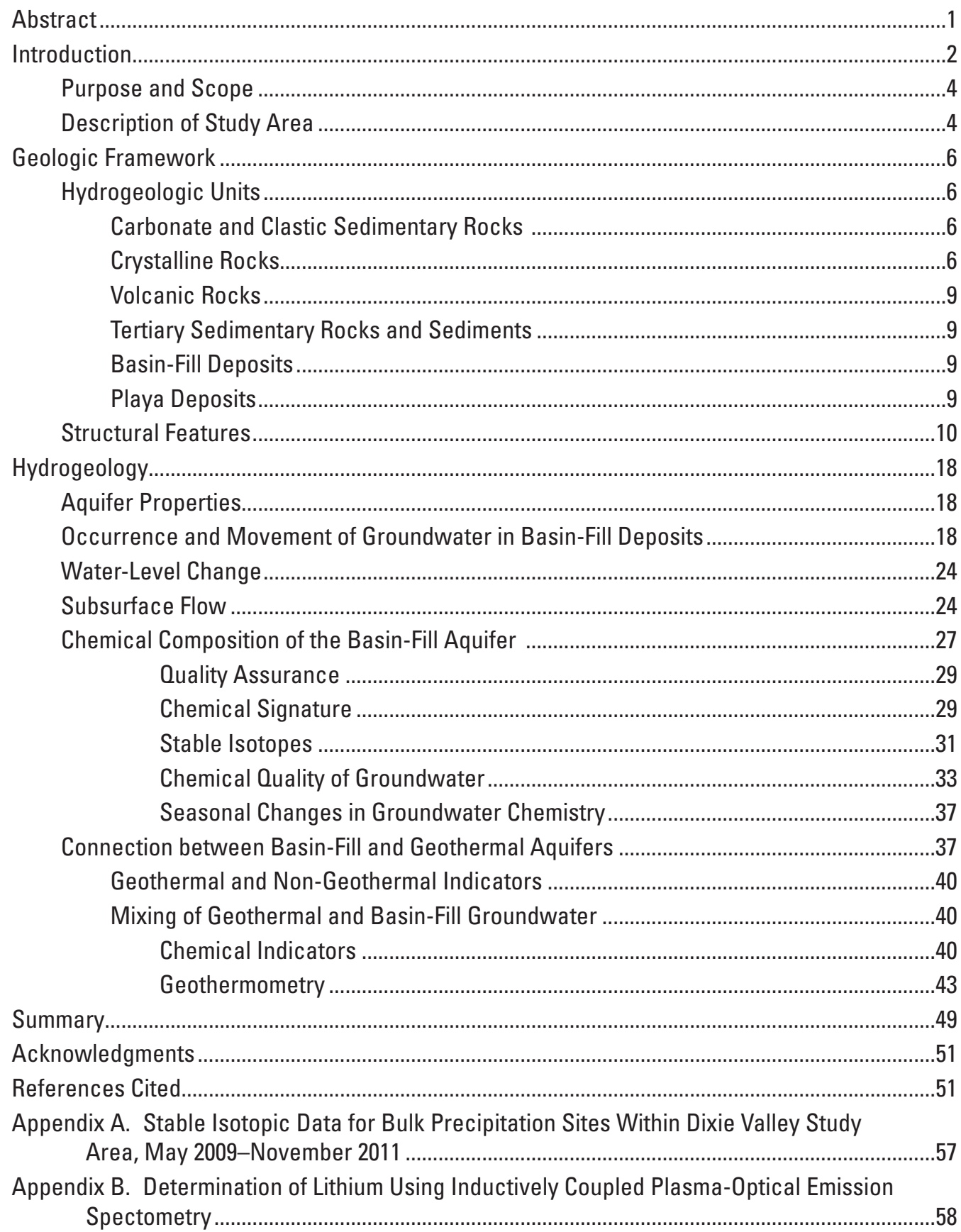




\section{Plate}

[Available online only at http://pubs.usgs.gov/sir/2014/5152/.]

1. Potentiometric water-level elevation at selected wells and potentiometric contours of potentiometric water-level elevation, Dixie Valley, west-central Nevada, autumn 2009.

\section{Figures}

1. Map showing the flow system, including hydrographic area boundaries, and playa location, Dixie Valley, west-central Nevada.

2. Map showing hydrogeologic units, depth to bedrock, and known playa sediment depths, Dixie Valley, west-central Nevada

3. Conceptual cross-sectional diagram showing inter-fingering of clay-dominated playa and basin-fill sediments, and photograph showing typical playa-deposits during well drilling in Dixie Valley, west-central Nevada....

4. Map showing data collection sites in Dixie Valley, west-central Nevada, 2009-11 .......11

5. Map showing estimates of basin-fill transmissivity from single-well aquifer tests or specific-capacity calculations and water-temperature distributions in springs, Dixie Valley, west-central Nevada.

6. Graphs showing water-level change as indicated by intermittent, selected water-level measurements from eight wells in the northernmost basin, north of playa near Dixie Valley Geothermal Plant, just south of playa, and in southernmost basin, Dixie Valley, west-central Nevada, 1955-2011

7. Map showing locations of sites sampled for water quality and measured field groundwater temperature, Dixie Valley, west-central Nevada, 1959-2011

8. Trilinear diagram showing general water-quality conditions in northern and southern areas of Dixie Valley, west-central Nevada

9. Graphs showing isotopic signature of groundwater, springs, and precipitation at selected sites in Dixie Valley, west-central Nevada, 2009-11

10. Map showing fluoride concentrations in groundwater from sites and maximum contaminant level exceedances in the basin-fill aquifer, Dixie Valley, west-central Nevada

11. Map showing total dissolved solids concentrations in groundwater from sites and secondary maximum contaminant level exceedance distributions in the basin-fill aquifer, Dixie Valley, west-central Nevada

12. Map showing magnesium concentrations in groundwater from sites in Dixie Valley, west-central Nevada

13. Graph showing relation between the molar ratio of magnesium to lithium and average geothermal silicon in geothermal groundwater samples, Dixie Valley, west-central Nevada 


\section{Figures-Continued}

14. Graph showing mixing between water high in silica (SiO2) and lithium (Li) with water high in magnesium and low in $\mathrm{SiO} 2$ and $\mathrm{Li}$, and water temperature, Dixie Valley, west-central Nevada

15. Graph showing relation between boron and lithium concentrations, and water temperature in basin-fill groundwater samples collected in this study and in historical basin-fill and geothermal groundwater samples, Dixie Valley, west-central Nevada .

16. Map showing lithium concentrations in groundwater from sites in Dixie Valley, west-central Nevada .

17. Map showing locations of magnesium-lithium geothermometers and temperatures recorded in Dixie Valley, west-central Nevada

\section{Tables}

1. Hydrographic areas of the Dixie Valley flow system, west-central Nevada ......................5

2. Hydrogeologic unit characteristics, Dixie Valley, west-central Nevada ............................8

3. Well information, static water levels, and types of data collected in the Dixie Valley flow system, west-central Nevada

4. Basin-fill transmissivity estimated from single-well and multiple-well aquifer tests, specific-capacity estimates, slug tests, and well characteristics, Dixie Valley, west-central Nevada

5. Locations, elevations, and temperatures in springs and Quaternary faults in the Dixie Valley flow system, west-central Nevada.

6. Water-quality data from sites sampled in Dixie Valley, west-central Nevada, 2009-11

7. Wells with seven or more water-level measurements, Dixie Valley, west-central Nevada, 1950-2011

8. Annual subsurface inflow estimates from adjacent basins through basin-fill deposits to Dixie Valley, west-central Nevada

9. Summary of drinking-water standards and exceedances for groundwater sites in the basin-fill aquifer, Dixie Valley, west-central Nevada

10. Selected chemical constituent concentration and percentage of change for samples collected in Dixie Valley, west-central Nevada, October 2009 and May 2010

11. Estimated reservoir temperatures based on magnesium-lithium geothermometer compared to sodium-potassium-calcium geothermometer and measured field groundwater temperatures, Dixie Valley, west-central Nevada 


\section{Conversion Factors, Datums, Township and Range, and Abbreviations and Acronyms}

\section{Conversion Factors}

\begin{tabular}{|c|c|c|}
\hline Multiply & By & To obtain \\
\hline \multicolumn{3}{|c|}{ Length } \\
\hline inch (in.) & 2.54 & centimeter (cm) \\
\hline inch (in.) & 25.4 & millimeter (mm) \\
\hline foot (ft) & 0.3048 & meter $(\mathrm{m})$ \\
\hline mile (mi) & 1.609 & kilometer (km) \\
\hline \multicolumn{3}{|c|}{ Area } \\
\hline acre & 4,047 & square meter $\left(\mathrm{m}^{2}\right)$ \\
\hline square mile $\left(\mathrm{mi}^{2}\right)$ & 2.590 & square kilometer $\left(\mathrm{km}^{2}\right)$ \\
\hline \multicolumn{3}{|c|}{ Volume } \\
\hline acre-foot (acre-ft) & 1,233 & cubic meter $\left(\mathrm{m}^{3}\right)$ \\
\hline \multicolumn{3}{|c|}{ Flow rate } \\
\hline acre-foot per year (acre-ft/yr) & 1,233 & cubic meter per year (m³/yr) \\
\hline gallon per minute (gal/min) & 0.06309 & liter per second (L/s) \\
\hline gallon per day (gal/d) & 0.003785 & cubic meter per day (m³/d) \\
\hline inch per year (in/yr) & 25.4 & millimeter per year (mm/yr) \\
\hline \multicolumn{3}{|c|}{ Energy } \\
\hline megawatt hour (MWh) & $3,600,000,000$ & joule $(\mathrm{J})$ \\
\hline \multicolumn{3}{|c|}{ Hydraulic conductivity } \\
\hline foot per day (ft/d) & 0.3048 & meter per day $(\mathrm{m} / \mathrm{d})$ \\
\hline \multicolumn{3}{|c|}{ Hydraulic gradient } \\
\hline foot per foot (ft/ft) & 0.3048 & meter per meter (m/m) \\
\hline \multicolumn{3}{|c|}{ Transmissivity* } \\
\hline foot squared per day $\left(\mathrm{ft}^{2} / \mathrm{d}\right)$ & 0.09290 & meter squared per day $\left(\mathrm{m}^{2} / \mathrm{d}\right)$ \\
\hline
\end{tabular}

Temperature in degrees Celsius $\left({ }^{\circ} \mathrm{C}\right)$ may be converted to degrees Fahrenheit $\left({ }^{\circ} \mathrm{F}\right)$ as follows:

$$
{ }^{\circ} \mathrm{F}=\left(1.8 \times{ }^{\circ} \mathrm{C}\right)+32
$$

Concentrations of chemical constituents in water are given either in milligrams per liter (mg/L) or micrograms per liter $(\mu \mathrm{g} / \mathrm{L})$.

*Transmissivity: The standard unit for transmissivity is cubic foot per day per square foot times foot of aquifer thickness [( $\left.\left.\mathrm{ft}^{3} / \mathrm{d}\right) / \mathrm{ft}^{2}\right] \mathrm{ft}$. In this report, the mathematically reduced form, foot squared per day $\left(\mathrm{ft}^{2} / \mathrm{d}\right)$, is used for convenience. 


\section{Conversion Factors, Datums, Township and Range, and Abbreviations and Acronyms}

\section{Datums}

Vertical coordinate information is referenced to North American Vertical Datum of 1988 (NAVD 88).

Horizontal coordinate information is referenced to the North American Datum of 1983 (NAD 83).

Elevation, as used in this report, refers to distance above the vertical datum.

\section{Township and Range}

A township is an approximately 6 -mile square area of land containing 36 sections. The Public Land Survey System (PLSS) numbers townships in horizontal rows and ranges in vertical columns so that each 6 square-mile area has a unique township-range number.

\section{Abbreviations and Acronyms}

$\begin{array}{ll}\text { bls } & \text { below land surface } \\ \text { ICP-OES } & \text { Inductively Coupled Plasma-Optical Emission Spectrometry } \\ \text { LMWL } & \text { local meteoric water line } \\ \text { MCL } & \text { maximum contaminant level } \\ \text { PRISM } & \text { Parameter-elevation Regressions on Independent Slopes Model } \\ r^{2} & \text { coefficient of determination } \\ \text { Reclamation } & \text { Bureau of Reclamation } \\ \text { SMCL } & \text { secondary maximum contaminant level } \\ \text { TDS } & \text { total dissolved solids } \\ \text { USGS } & \text { U.S. Geological Survey }\end{array}$





\title{
Hydrogeologic Framework and Occurrence, Movement, and Chemical Characterization of Groundwater in Dixie Valley, West-Central Nevada
}

\author{
By Jena M. Huntington, C. Amanda Garcia, and Michael R. Rosen
}

\begin{abstract}
Dixie Valley, a primarily undeveloped basin in west-central Nevada, is being considered for groundwater exportation. Proposed pumping would occur from the basin-fill aquifer. In response to proposed exportation, the U.S. Geological Survey, in cooperation with the Bureau of Reclamation and Churchill County, conducted a study to improve the understanding of groundwater resources in Dixie Valley. The objective of this report is to characterize the hydrogeologic framework, the occurrence and movement of groundwater, the general water quality of the basin-fill aquifer, and the potential mixing between basin-fill and geothermal aquifers in Dixie Valley. Various types of geologic, hydrologic, and geochemical data were compiled from previous studies and collected in support of this study. Hydrogeologic units in Dixie Valley were defined to characterize rocks and sediments with similar lithologies and hydraulic properties influencing groundwater flow. Hydraulic properties of the basin-fill deposits were characterized by transmissivity estimated from aquifer tests and specific-capacity tests. Groundwater-level measurements and hydrogeologic-unit data were combined to create a potentiometric surface map and to characterize groundwater occurrence and movement. Subsurface inflow from adjacent valleys into Dixie Valley through the basin-fill aquifer was evaluated using hydraulic gradients and Darcy flux computations. The chemical signature and groundwater quality of the Dixie Valley basin-fill aquifer, and potential mixing between basin-fill and geothermal aquifers, were evaluated using chemical data collected from wells and springs during the current study and from previous investigations.

Dixie Valley is the terminus of the Dixie Valley flow system, which includes Pleasant, Jersey, Fairview, Stingaree, Cowkick, and Eastgate Valleys. The freshwater aquifer in the study area is composed of unconsolidated basin-fill deposits of Quaternary age. The basin-fill hydrogeologic
\end{abstract}

unit can be several orders of magnitude more transmissive than surrounding and underlying consolidated rocks and Dixie Valley playa deposits. Transmissivity estimates in the basin fill throughout Dixie Valley ranged from 30 to 45,500 feet squared per day; however, a single transmissivity value of 0.1 foot squared per day was estimated for playa deposits.

Groundwater generally flows from the mountain range uplands toward the central valley lowlands and eventually discharges near the playa edge. Potentiometric contours east and west of the playa indicate that groundwater is moving eastward from the Stillwater Range and westward from the Clan Alpine Mountains toward the playa. Similarly, groundwater flows from the southern and northern basin boundaries toward the basin center. Subsurface groundwater flow likely enters Dixie Valley from Fairview and Stingaree Valleys in the south and from Jersey and Pleasant Valleys in the north, but groundwater connections through basin-fill deposits were present only across the Fairview and Jersey Valley divides. Annual subsurface inflow from Fairview and Jersey Valleys ranges from 700 to 1,300 acre-feet per year and from 1,800 to 2,300 acre-feet per year, respectively. Groundwater flow between Dixie, Stingaree, and Pleasant Valleys could occur through less transmissive consolidated rocks, but only flow through basin fill was estimated in this study.

Groundwater in the playa is distinct from the freshwater, basin-fill aquifer. Groundwater mixing between basin-fill and playa groundwater systems is physically limited by transmissivity contrasts of about four orders of magnitude. Total dissolved solids in playa deposit groundwater are nearly 440 times greater than total dissolved solids in the basin-fill groundwater. These distinctive physical and chemical flow restrictions indicate that groundwater interaction between the basin fill and playa sediments was minimal during this study period (water years 2009-11). 
Groundwater in Dixie Valley generally can be characterized as a sodium bicarbonate type, with greater proportions of chloride north of the Dixie Valley playa, and greater proportions of sulfate south of the playa. Analysis of major ion water chemistry data sampled during the study period indicates that groundwater north and south of Township 22N differ chemically. Dixie Valley groundwater quality is marginal when compared with national primary and secondary drinking-water standards. Arsenic and fluoride concentrations exceed primary drinking water standards, and total dissolved solids and manganese concentrations exceed secondary drinking water standards in samples collected during this study. High concentrations of boron and tungsten also were observed.

Chemical comparisons between basin-fill and geothermal aquifer water indicate that most basin-fill groundwater sampled could contain 10-20 percent geothermal water. Geothermal indicators such as high temperature, lithium, boron, chloride, and silica suggest that mixing occurs in many wells that tap the basin-fill aquifer, particularly on the north, south, and west sides of the basin. Magnesium-lithium geothermometers indicate that some basin-fill aquifer water sampled for the current study likely originates from water that was heated above background mountain-block recharge temperatures (between 3 and 15 degrees Celsius), highlighting the influence of mixing with warm water that was possibly derived from geothermal sources.

\section{Introduction}

Quantification of water resources is essential in the arid Southwest, where demand for water is increasing because of population growth. One of the driest states in the United States, Nevada, increased in population by 35 percent between 2000 and 2010 (U.S. Census Bureau, 2011). Most of this population increase occurred in urban areas. Finite water resources in urban areas have led to the implementation of large-scale water importation projects, which commonly include applications for additional, new water appropriations. In order to sustain continued growth in the Fallon urban area of the Carson Desert, Churchill County is investigating additional water resources. Dixie Valley, primarily an undeveloped basin neighboring the Carson Desert to the east (fig. 1), is considered a potential resource for water importation to the Carson Desert (Public Law 110-161, Section 208). Proposed groundwater pumping would be from the fresh basin-fill aquifer.

A large amount of research and exploration has been done in Dixie Valley since the 1960s. The first hydrologic report for the valley and basin-fill aquifers (Cohen and Everett, 1963) included water-budget estimates (recharge, groundwater evapotranspiration, and subsurface inflow), a limited groundwater quality evaluation, and a map showing waterlevel elevations. This reconnaissance-level report described multiple groundwater systems in Dixie Valley including a freshwater basin-fill system, a brine water playa-sediment system, and a deep, variable-quality geothermal system with elevated temperatures. In the 1990s, Harrill and Hines (1995) updated the 1963 basin-fill groundwater budget by incorporating groundwater evapotranspiration estimates based on mapped distributions of phreatophyte types and densities, and precipitation across the valley.

Much research completed in Dixie Valley has focused on describing geologic structure. A compilation report by Thompson and others (1967) documented the geologic structure in Dixie Valley using seismic refraction, aeromagnetic measurements, and mapping or interpretation of aerial photographs. In the early 1980s, Schaefer (1983) did a gravity survey across the valley to evaluate the depth to bedrock or base of basin-fill sediments. Mankhemthong and others (2008) gathered detailed gravity data in southern Dixie Valley and made interpretations of bedrock thicknesses.

The developed geothermal aquifer in northern Dixie Valley, near the Stillwater Range (fig. 1), is one of the most studied geothermal resources in the United States (Blackwell and others, 2007). Many studies have concentrated on describing the geologic structure of the geothermal field. Wilt and Goldstein (1983) did an aero-electromagnetic survey mapping areas of high-resistivity (low electrical conductivity) rock zones to help locate geothermal waters. Barton and others (1997) used flow, temperature, and imaging logs from boreholes extending into the geothermal reservoir to locate hydraulically conductive fractures in bedrock adjacent to the Stillwater Fault located along the eastern face of the Stillwater Range. Additional work was done by Blackwell and others (1999) and Smith and others (2001) to characterize the complex faulting associated with the main Stillwater Fault, including gravity surveys, seismic lines, field mapping, and aerial photo analyses. In 2002, another aero-electromagnetic survey conducted over a larger (than the geothermal field) area of Dixie Valley (U.S. Geological Survey, and Pearson, deRidder, and Johnson, Inc., 2002) was used to locate shallow faults not visible at land surface (Grauch, 2002). Caine and others (2010) further investigated geothermal fluid flow using field mapping and rock characterization along fault lines. Many other studies have focused on the Dixie Valley geothermal field, some of which are listed on the Geothermal Resources Council Web site, at https://www.geothermallibrary.org/.

The Dixie Valley Geothermal Power Plant, in northwestern Dixie Valley (fig. 1), produces the largest amount of geothermal energy from a single plant in the State of Nevada (Lowell Price, Nevada Division of Minerals, oral commun., 2012). Pumping from the geothermal aquifer for power production began in 1985, and pressure augmentation pumping from the basin-fill aquifer for reinjection above the geothermal aquifer began in 1997; pumping from both aquifers continues today (2014). 


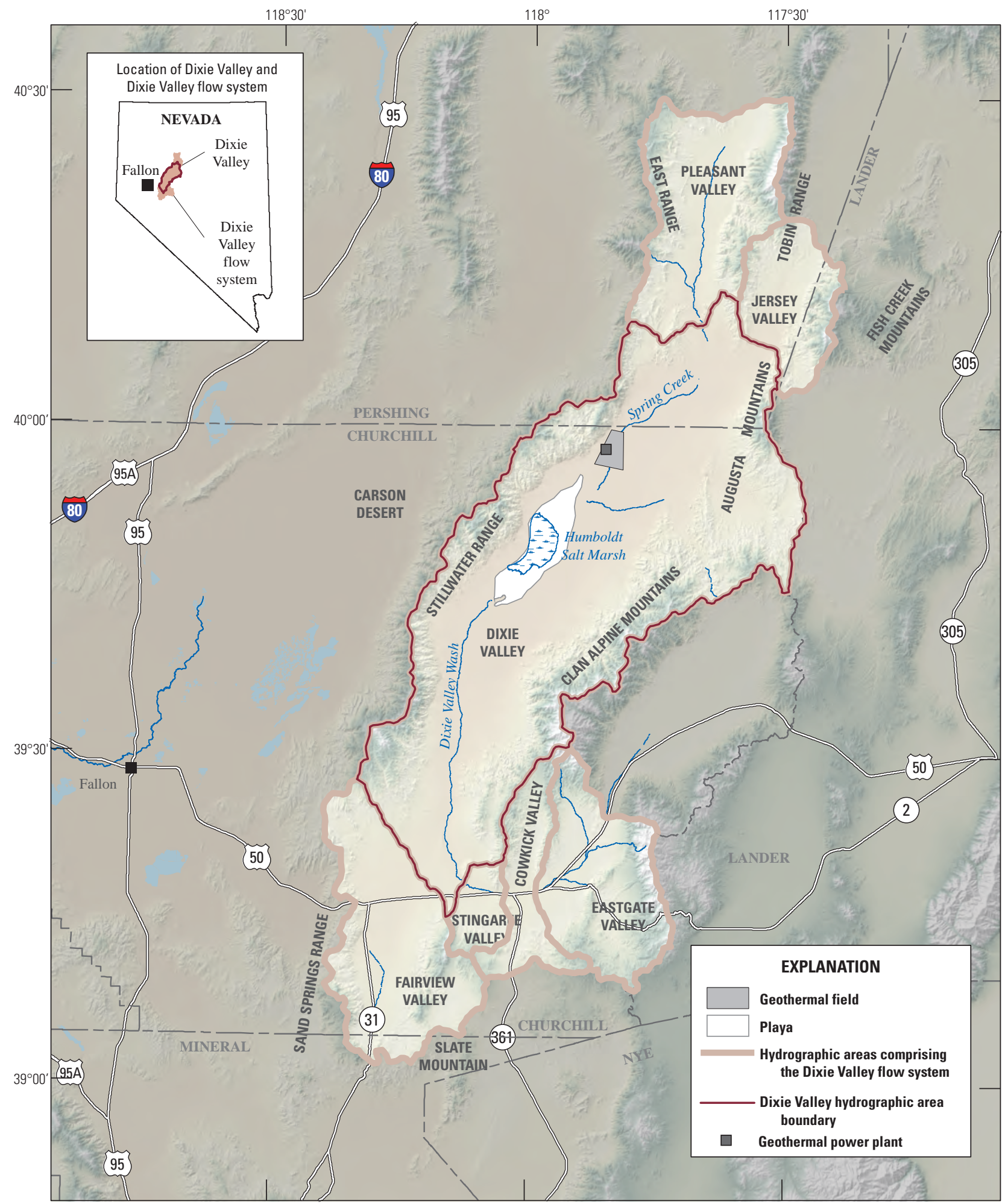

Base from U.S. Geological Survey digital data, 1:24,000, 2010. Universal Transverse Mercator projection, Zone 11 North American Datum of 1983

Shaded-relief base from 10-meter National Elevation Data, 2011.

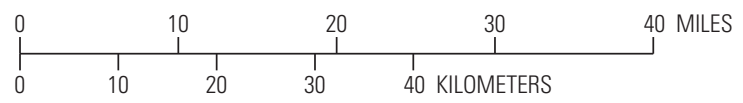

Figure 1. Flow system, including hydrographic area boundaries, and playa location, Dixie Valley, west-central Nevada. 
During water years ${ }^{1} 2010-11$, average annual geothermal groundwater withdrawals totaled about 21,400 acre-ft (23,600 and 19,200 acre-ft in 2010 and 2011, respectively), with an average water temperature of about $160{ }^{\circ} \mathrm{C}$. About 487,000 megawatt hours of energy were produced annually from this water. About 15,000 acre-ft were re-injected annually, resulting in an average annual consumptive use of geothermal water of about 6,600 acre-ft (about 9,600 and 3,600 acre-ft in 2010 and 2011, respectively) (Lowell Price, Nevada Division of Minerals, written commun., 2012). Little is known about potential interactions between the different geothermal systems and the basin-fill aquifer, although one study (Bruton and others, 1997) indicated that there could be 15-25 percent geothermal water in the basin-fill aquifer, and another study (Nimz and others, 1999) indicated that geothermal water might have been derived from local recharge. Several investigations have sampled for water chemistry and hydrogen and oxygen isotopes from basin-fill aquifers, springs, and geothermal wells (Cohen and Everett, 1963; Garside, 1994; Nimz and others, 1999; Stamates, 2001; Goff and others, 2002; Lahontan GeoScience, Inc., 2004) to characterize potability and the hydrologic relations between basin-fill and geothermal aquifers. A more comprehensive investigation of the basin-fill aquifer and potential interactions with geothermal systems was needed to understand how basin-fill groundwater exportation might affect geothermal resources in Dixie Valley.

With competing water exportation and geothermal development interests, an improved understanding of the groundwater resources is necessary before additional groundwater development in Dixie Valley can reasonably be considered. County and State water-resource managers will need this information to make informed decisions regarding the proposed inter-basin water transfer. To address these needs and concerns, the U.S. Geological Survey (USGS), in cooperation with the Bureau of Reclamation (Reclamation) and Churchill County, evaluated the groundwater resources of Dixie Valley in west-central Nevada. A companion USGS report by Garcia and others (2014) describes a refined estimate of groundwater discharge from evapotranspiration in Dixie Valley.

\section{Purpose and Scope}

This report characterizes the occurrence, movement, and chemistry of the basin-fill aquifer by evaluating the hydrogeologic features controlling groundwater resources

\footnotetext{
${ }^{1} \mathrm{~A}$ "water year" is the 12-month period from October 1 , for any given year, through September 30 of the following year and is designated by the calendar year in which it ends.

${ }^{2}$ Formal hydrographic areas in Nevada were delineated systematically by the U.S. Geological Survey and Nevada Division of Water Resources in the late 1960s for scientific and administrative purposes (Cardinalli and others, 1968; Rush, 1968). The official hydrographic-area names, numbers, and geographic boundaries continue to be used in U.S. Geological Survey scientific reports and Nevada Division of Water Resources administrative activities.
}

in Dixie Valley. Groundwater resources were evaluated by delineating the hydrogeologic framework, estimating aquifer properties, describing groundwater-flow directions and gradients in the valley, characterizing the general quality of groundwater from the principal basin-fill aquifer, and evaluating potential interactions between the basin-fill and geothermal aquifers. This report provides a reassessment of the groundwater flow regime. The hydrogeologic framework was based on geologic and hydrogeologic studies completed during the past 50 years. Aquifer properties were estimated from a series of aquifer and specific capacity tests. Groundwater-flow directions and gradients were derived from water-level elevation measurements made primarily during this study, whereas changes in water-level elevation were evaluated from data collected since the 1950s. The chemical quality of the basin-fill aquifers was characterized using water-quality data from previously published datasets (samples collected from 1959 to 2004) and sites sampled for this study during water years 2009-11.

\section{Description of Study Area}

The Dixie Valley flow system covers an area of about 2,380 $\mathrm{mi}^{2}$ (Nevada Division of Water Resources, 2012) in west-central Nevada, mainly is in Churchill County (with smaller parts in Pershing, Lander, and Mineral Counties), and consists of seven hydrographic areas²: Pleasant Valley, Jersey Valley, Fairview Valley, Dixie Valley, Stingaree Valley, Cowkick Valley, and Eastgate Valley (fig. 1; table 1). Dixie Valley is the terminus of the basin-fill groundwater flow system and the focus of this report. Surface water in six of the hydrographic areas (except Fairview Valley) drains into Dixie Valley. Fairview Valley is drained internally or is a closed basin, meaning no surface water leaves the valley. Groundwater flow from all hydrographic areas historically was thought to drain into Dixie Valley through basin-fill sediments (Cohen and Everett, 1963, p. 3).

Dixie Valley is a northeast-trending structural trough (Schaefer, 1983) covering an area of 1,303 $\mathrm{mi}^{2}$ (Cardinalli and others, 1968; Rush, 1968; table 1). The valley is bordered on the west and northwest by the Stillwater Range, and on the east and southeast by the Augusta and Clan Alpine Mountains (fig. 1). The southern end of Dixie Valley is bounded by a low range of hills between the Sand Springs Range and Slate Mountain, which form the boundary with Fairview Valley. An alluvial divide between the East and Tobin Ranges creates the northwestern boundary with Pleasant Valley, and a second alluvial divide connecting the Tobin Range to the Augusta Mountains forms the northeastern boundary with Jersey Valley. Each alluvial divide has an elevation of about 4,900 ft (Cohen and Everett, 1963). Land-surface elevations in the study area range from 9,900 ft in the Clan Alpine Mountains to 3,380 ft on the Humboldt Salt Marsh, which is in the center of the Dixie Valley playa. The Dixie Valley playa represents the lowest point in northern Nevada (Cohen and Everett, 1963). 
Table 1. Hydrographic areas of the Dixie Valley flow system, west-central Nevada.

[Areas are shown in figure 1 and designated by the U.S. Geological Survey and Nevada Division of Water Resources for scientific and administrative purposes (Cardinalli and others, 1968; Rush, 1968)]

\begin{tabular}{lccr}
\hline \multirow{2}{*}{ Name } & \multirow{2}{*}{$\begin{array}{c}\text { Identification } \\
\text { No. }\end{array}$} & \multicolumn{2}{c}{ Area } \\
\cline { 3 - 4 } & & (square miles) & (acres) \\
\hline Dixie Valley & 128 & 1,303 & 833,920 \\
Pleasant Valley & 130 & 285 & 182,400 \\
Jersey Valley & 132 & 142 & 90,880 \\
Fairview Valley & 124 & 285 & 182,400 \\
Stingaree Valley & 125 & 43 & 27,520 \\
Cowkick Valley & 126 & 110 & 70,400 \\
Eastgate Valley & 127 & 216 & 138,240 \\
\multicolumn{1}{c}{ Totals } & & 2,384 & $1,525,760$ \\
\hline
\end{tabular}

The climate in the mountains of Dixie Valley is categorized as sub-humid with orographic effects similar to those of the Sierra Nevada Mountains but of a lesser magnitude, whereas climate in the valley lowlands is arid (Cohen and Everett, 1963, p. 5). Therefore, annual precipitation varies substantially with elevation in Dixie Valley and the adjoining ranges. In the Stillwater Range and Clan Alpine Mountains, annual precipitation averaged 13.3 and 14.5 in., respectively during October 2009-September 2011 (Chris Mahannah, Mahannah and Associates, LLC, written commun., 2011). The 30-year average annual precipitation from the Parameter-elevation Regressions on Independent Slopes Model (PRISM) was estimated as 10.6 and 10.7 in., respectively (1981-2010; PRISM Climate Group, 2004). On the playa, annual precipitation averaged 5.2 in. during this study (October 2009-September 2011; Garcia and others, 2014). Precipitation predominantly occurs in the winter as snow in the mountains, and as a mix of snow and rain on the valley floor. Lesser amounts of precipitation fall on the valley floor as rain from isolated thunderstorms in the spring, summer, and autumn. Seasonal temperatures in valley lowlands range from about -10 to $40{ }^{\circ} \mathrm{C}$ (Garcia and others, 2014).

Only ephemeral streams fed by spring snowmelt or infrequent, major storms, or intermittent streams fed by springs, are present in Dixie Valley (fig. 1). All streams flow toward the Dixie Valley playa, although little surface water (less than 500 acre-feet per year [acre-ft/yr]) actually is discharged onto the playa (Interflow Hydrology, Inc. and Mahannah and Associates, LLC, 2013). Most streamflow that originates from the mountain front is lost to infiltration or evapotranspiration before reaching the playa (Cohen and Everett, 1963; Interflow Hydrology, Inc. and Mahannah and Associates, LLC, 2013). Dixie Valley Wash is the predominant stream in the valley that enters Dixie Valley from Stingaree Valley to the south, and flows ephemerally about $40 \mathrm{mi}$ north until it discharges onto the Dixie Valley playa (fig. 1). Spring Creek flows ephemerally from Pleasant Valley southward into Dixie Valley.
Dixie Valley has many cool and geothermal springs that discharge in the Clan Alpine Mountains and Stillwater Range, along the mountain front, and on the valley floor, several of which are adjacent to the Dixie Valley playa. Current discharge rates and temperatures of valley-floor springs range from less than 1 to 300 gallons per minute (Interflow Hydrology, Inc. and Mahannah and Associates, LLC, 2012a), and from 4 to more than $60^{\circ} \mathrm{C}$. Vegetation surrounding spring discharge areas on the valley floor is composed mostly of thick grasses with some trees and reeds, indicating that most discharge is lost to evapotranspiration.

Groundwater in Dixie Valley is present in several aquifer systems. Groundwater persists primarily within the fresh basin-fill aquifer (depths of as much as nearly $10,000 \mathrm{ft}$ below land surface [bls]) and the saline playa confining unit. Deep groundwater (maximum estimated depth of 20,000 ft bls; Blackwell and others, 2003; McKenna and Blackwell, 2004; Wisian and Blackwell, 2004) has been found in at least 12 geothermal aquifer systems within consolidated rock (Benoit, 2011).

Dixie Valley is sparsely populated, with less than 100 residents (Katy Rossiter, U.S. Census Bureau, written commun., 2011). Consequently, domestic groundwater development from basin-fill deposits is negligible, equating to less than 25 acre-ft/yr based on the Nevada domestic selfsupplied, per-capita use of 206 gallons per day (gal/d) (Kenny and others, 2009). Current and historical use of basin-fill groundwater includes livestock, agricultural irrigation, domestic, and geothermal development. Cattle are grazed throughout much of the valley rangeland, and alfalfa is cultivated for seed and feed. Currently irrigated agriculture covers about 1,360 acres of Dixie Valley. However, agriculture historically covered more than three times as much of the current agricultural landscape, much of which was in the historical agricultural settlement (1940-80s) just south of the playa. Many artesian wells were drilled to sustain irrigation and domestic requirements in this settlement area.

Large-scale pumping of the basin-fill aquifer to augment the pressure of the geothermal reservoir began in 1997 (Benoit and others, 2000). The Dixie Valley geothermal power plant in northwestern Dixie Valley pumps an average of 2,100 acre-ft/yr from the basin-fill aquifer surrounding the plant (period of record, 2009-11; Nevada Division of Minerals, written commun., 2012), all of which subsequently is re-injected above the deeper (500-9,700 ft bls) geothermal aquifer. Just north of the geothermal well field, subsidence rates of as much as $4.1 \mathrm{in} / \mathrm{yr}$ between 1992 and 1997 (Foxall and Vasco, 2003) and $1.8 \mathrm{in} / \mathrm{yr}$ between 2006 and 2008 (John Bell, Nevada Bureau of Mines and Geology, written commun., 2010) were documented in interferometric synthetic aperture radar data. If these rates are applied at $4.1 \mathrm{in} / \mathrm{yr}$ from 1992 to 2001 and at $1.8 \mathrm{in} / \mathrm{yr}$ from 2001 to 2011, total subsidence in the affected area could be nearly 59 in. Additional geothermal exploration currently is being done in several locations throughout Dixie Valley, as well as in Jersey Valley. 


\section{Geologic Framework}

Dixie Valley is a complex asymmetric graben bounded by high-angle normal faults. The bedrock basin is composed of subbasins separated by bedrock highs in which basin-fill deposits of Quaternary age have accumulated. The bedrock beneath the basin fill and adjacent mountains is composed of clastic sedimentary and crystalline rocks ranging in age from Triassic to Tertiary and mostly extrusive volcanic rocks of Tertiary age (Willden and Speed, 1974). Hydrogeologic features of Dixie Valley that partly control groundwater flow include lithology and sediments through which flow occurs, lithology and sediment thicknesses and hydraulic properties, and the structural components of the valley.

\section{Hydrogeologic Units}

Maurer and others (2004) delineated 12 hydrogeologic units in Dixie Valley based on the 1:500,000-scale geologic map of Nevada (Stewart and Carlson, 1978). In this study, these 12 hydrogeologic units were grouped into 6 hydrogeologic units based on lithology (ig. 2 ; table 2). Rocks and sediments with similar lithologies generally were assumed to have similar hydraulic properties affecting groundwater flow. The six hydrogeologic units that either transmit or impede groundwater flow, from oldest to youngest, include: (1) carbonate and clastic sedimentary rocks of Triassic-to-Jurassic age; (2) crystalline rocks of Triassic-to-Tertiary age; (3) volcanic rocks of Tertiary age; (4) sedimentary rocks and sediments of Tertiary age; (5) basin-fill deposits of Quaternary age; and (6) playa deposits of Quaternary age.

The primary hydraulic properties controlling groundwater movement include porosity, hydraulic conductivity, and transmissivity. Porosity controls the volume of water that can be stored within a rock or unconsolidated sediment. Primary porosity is a measure of the open pore space within the crystalline structure and (or) sediment grains of a rock, and is directly affected by grain sorting (Lohman and others, 1972, p. 4). With the exception of extrusive igneous or volcanic rocks, the primary porosity of unconsolidated sediments generally is greater than that of consolidated rocks because pore spaces between sediment grains are more numerous and more interconnected than pores in consolidated rock (Maurer and others, 2004, p. 4). Volcanic rocks can develop secondary porosity from open spaces along fractures and joints, or from dissolution of rocks along fractures and joints (Lohman, 1979, p. 4).

Hydraulic conductivity and transmissivity describe the rate at which water moves through an aquifer (Lohman and others, 1972, p. 4). The hydraulic conductivity of basin-fill deposits generally is related to primary porosity and can vary by six orders of magnitude (Maurer and others, 2004, p. 6). The hydraulic conductivity of consolidated rocks depends mostly on the degree of fracturing (secondary porosity) and respective fracture permeability, and can vary by 12 orders of magnitude (Maurer and others, 2004, p. 6). Transmissivity describes the rate of groundwater movement through a section of aquifer and is expressed as the product of local hydraulic conductivity and saturated unit aquifer thickness (Lohman, 1979, p. 6). Transmissivity is a large-scale or "bulk" aquifer property, whereas hydraulic conductivity is a property that can vary between and within rock and sediment types. Therefore, it is possible for an aquifer to have a low transmissivity even if it contains fractions of material with high hydraulic conductivity.

\section{Carbonate and Clastic Sedimentary Rocks}

Carbonate and clastic sedimentary rocks in the mountains adjacent to Dixie Valley are present in the Stillwater Range and the Clan Alpine and Augusta Mountains, and are exposed mostly from the central to northern parts of the mountain block (fig. 2). Rock types are composed of limestone, dolomite, sandstone, siltstone, conglomerate, and shale ranging in age from Early Triassic to Middle Jurassic (Stewart and Carlson, 1978) (table 2). Many of these rocks have undergone some low-grade metamorphism (Page, 1965).

The hydraulic conductivity of the combined carbonate and clastic sedimentary unit likely is variable owing to the range of lithologies present. Carbonate rocks can have greater hydraulic conductivity due to fracturing and where groundwater dissolution has widened fractures through time (Plume, 1996, p. B11). As a result, hydraulic conductivity can range from $3 \times 10^{-5}$ to $3,300 \mathrm{ft} / \mathrm{d}$ (Maurer and others, 2004, table 2). Hydraulic conductivities of clastic sedimentary rocks typically are low $\left(2 \times 10^{-9}-20 \mathrm{ft} / \mathrm{d}\right)$ owing to either cementation (calcium carbonate or silica) or some degree of metamorphism (Maurer and others, 2004, table 2). When clastic rocks are interbedded or in contact with rock units of greater hydraulic conductivity (such as carbonate rocks or basin-fill deposits), they often are considered barriers to groundwater flow (Davis and DeWiest, 1966, p. 347; D’Agnese and others, 1997, p. 20; Harrill and Prudic, 1998, p. A19).

\section{Crystalline Rocks}

Few crystalline rocks are present in Dixie Valley relative to other rock types (fig. 2). Granitic rocks, such as quartz monzonite, of Triassic-to-Tertiary age, and intrusive rhyolites of Tertiary age, are present mostly near the southern part of Dixie Valley, in the Stillwater Range and the Clan Alpine Mountains. Gabbroic complexes of Early and Middle Jurassic age (Humboldt lopolith) are exposed mostly in the Stillwater Range and include gabbro, basalt, and associated quartz sandstone (Stewart, 1980, p. 71).

These crystalline rocks likely extend to great depths and have hydraulic conductivity ranging from $7 \times 10^{-8}$ to $30 \mathrm{ft} / \mathrm{d}$ (Maurer and others, 2004, table 2). The hydraulic conductivity of rhyolite likely is higher than that of other crystalline rocks owing to fracturing. 


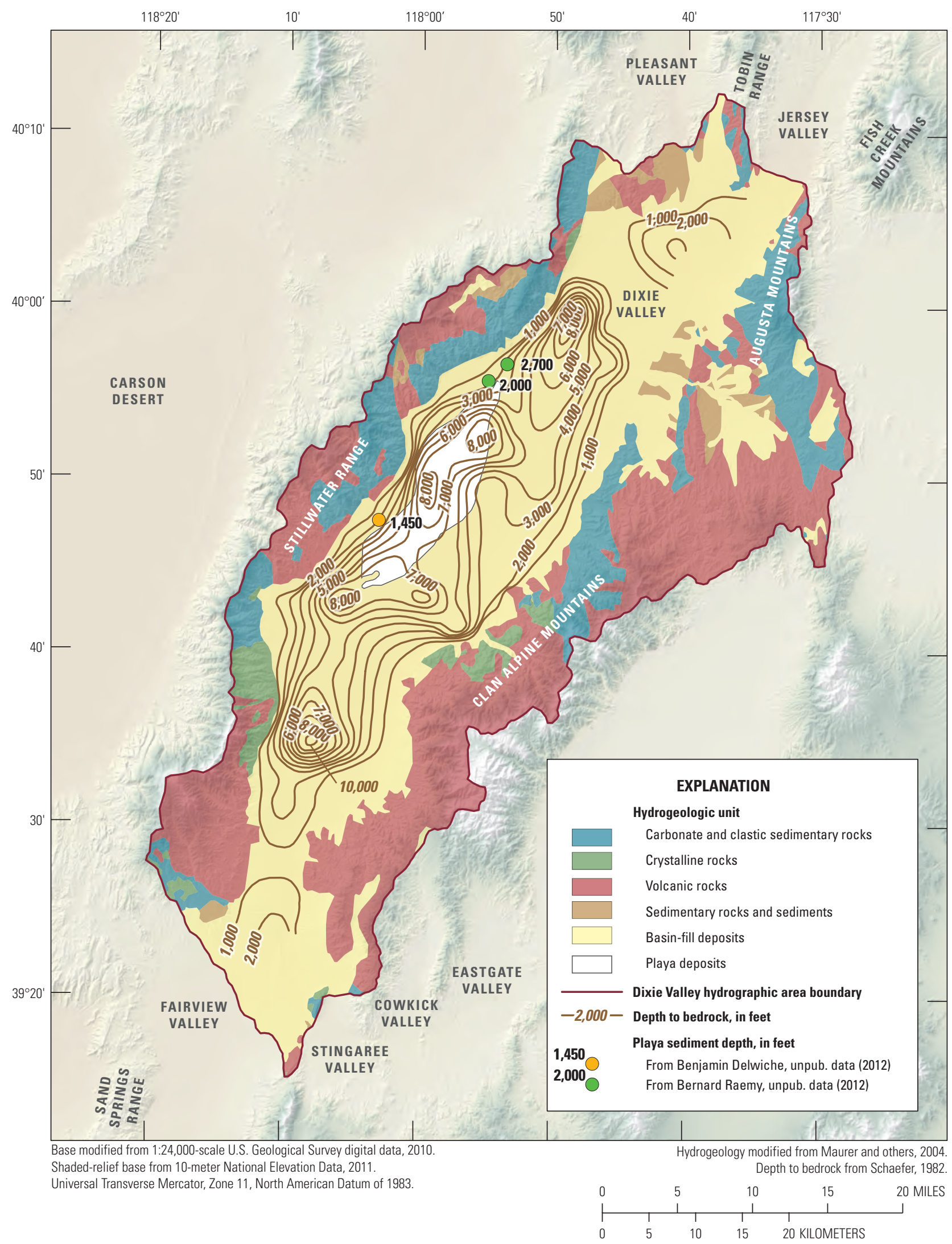

Figure 2. Hydrogeologic units, depth to bedrock, and known playa sediment depths, Dixie Valley, west-central Nevada. 
Table 2. Hydrogeologic unit characteristics, Dixie Valley, west-central Nevada.

\begin{tabular}{|c|c|c|c|}
\hline Geologic age & Rock or stratigraphic unit & Lithology & Water-bearing characteristics \\
\hline \multicolumn{4}{|c|}{ Carbonate and clastic sedimentary rocks } \\
\hline Triassic & $\begin{array}{l}\text { Tobin Formation } \\
\text { Dixie Valley Formation } \\
\text { Augusta Mountain } \\
\text { Formation } \\
\text { Cane Springs Formation }\end{array}$ & $\begin{array}{l}\text { Sandstone, siltstone, mudstone, } \\
\text { conglomerate, limestone, shale, and } \\
\text { dolomite. Each formation overlies the } \\
\text { next. }\end{array}$ & $\begin{array}{l}\text { Generally impedes the movement } \\
\text { of groundwater. Hydraulic } \\
\text { conductivity of carbonate rocks } \\
\text { ranges from } 3 \times 10^{-5} \text { to } 3.3 \times 10^{3} \\
\text { feet per day (ft/d) owing to } \\
\text { secondary porosity; clastic } \\
\text { rocks range from } 2 \times 10^{-9} \text { to } 20 \\
\mathrm{ft} / \mathrm{d}\end{array}$ \\
\hline \multicolumn{4}{|c|}{ Crystalline rocks } \\
\hline $\begin{array}{l}\text { Triassic, Jurassic, } \\
\text { Cretaceous, and Tertiary }\end{array}$ & Humboldt lopolith & $\begin{array}{l}\text { Gabbroic complexes consisting of } \\
\text { gabbro and basalt }\end{array}$ & $\begin{array}{l}\text { Impedes the movement of } \\
\text { groundwater. Hydraulic } \\
\text { conductivity ranges from } \\
7 \times 10^{-8} \text { to } 30 \mathrm{ft} / \mathrm{d} \text {. }\end{array}$ \\
\hline Tertiary & Volcanic rocks & $\begin{array}{l}\text { Lava flows of rhyolitic, basaltic, and } \\
\text { andesitic composition. Welded and } \\
\text { non-welded ash-flow tuffs of rhyolitic } \\
\text { and rhyodacitic composition. }\end{array}$ & $\begin{array}{l}\text { Typically impedes the movement } \\
\text { of groundwater. Hydraulic } \\
\text { conductivity ranges from } \\
3 \times 10^{-7} \text { to } 1.3 \times 10^{3} \mathrm{ft} / \mathrm{d} \text {. }\end{array}$ \\
\hline \multicolumn{4}{|c|}{ Sedimentary rocks and sediments } \\
\hline Tertiary & $\begin{array}{l}\text { Sedimentary rocks } \\
\text { and sediments }\end{array}$ & $\begin{array}{l}\text { Fine-grained semi-consolidated } \\
\text { sediments of limestone, diatomite, } \\
\text { tuffaceous shale, sandstone, and pebble } \\
\text { conglomerate interbedded with basalt } \\
\text { and tuff. }\end{array}$ & $\begin{array}{l}\text { Generally impedes the movement } \\
\text { of groundwater. Hydraulic } \\
\text { conductivity ranges from } 2 \times 10^{-4} \\
\text { to } 20 \mathrm{ft} / \mathrm{d} \text {. }\end{array}$ \\
\hline Quaternary & $\begin{array}{l}\text { Playa deposits, includes } \\
\text { Humboldt Salt Marsh }\end{array}$ & $\begin{array}{l}\text { Mostly clay and minor silt in lowest } \\
\text { central part of the valley. }\end{array}$ & $\begin{array}{l}\text { Comprise confined aquifers to } \\
\text { unknown depths. Acts as barrier } \\
\text { to groundwater flow. Hydraulic } \\
\text { conductivity about } 7 \times 10^{-4} \mathrm{ft} / \mathrm{d} \text {. }\end{array}$ \\
\hline
\end{tabular}




\section{Volcanic Rocks}

Volcanic rocks of Tertiary age are prevalent regionally and constitute a large part of exposed consolidated rocks in the mountain blocks surrounding Dixie Valley (fig. 2). Andesitic and basalt flow outcrops are scattered and laterally discontinuous, whereas those for rhyolitic, ash-flow, and welded tuffs are more extensive. Volcanic rocks, mostly basalt, also underlie basin-fill deposits throughout much of the valley (Wilt and Goldstein, 1983, p. 3-4; Abbott and others, 2001, fig. 10; Mankhemthong and others, 2008; Ben Delwiche, Ormat Technologies Inc., written commun., 2012). Caldera structures are present in the Stillwater Range and the Clan Alpine Mountains. (Ludington and others, 1996). The hydraulic conductivity of volcanic rocks can vary greatly $\left(3 \times 10^{-7}-1,300 \mathrm{ft} / \mathrm{d}\right)$, depending on the degree of jointing as the lava (or ash) flow solidified and was subsequently fractured by tectonic activity (Davis and DeWiest, 1996, p. 337; Maurer and others, 2004, table 2).

\section{Tertiary Sedimentary Rocks and Sediments}

Tertiary sedimentary rocks and sediments are composed of semi-consolidated sedimentary rocks of lacustrine or fluvial origin interbedded with volcanic basalt flows and tuffs. Sedimentary deposits are described as limestone, diatomite and opalized diatomite, tuffaceous shale, sandstone, claystone, and pebble conglomerate (Willden and Speed, 1974, p. 28; Johnson, 1977, p. 36; Stewart, 1980, p. 89-93). These sedimentary rocks and sediments are exposed near the northern end of Dixie Valley in the Clan Alpine Mountains and the Stillwater Range, but also underlie the younger basinfill deposits in some areas of the basin (Wilt and Goldstein, 1983, p. 3-4; Plume, 1996, p. B15; Abbott and others, 2001, fig. 10; Mankhemthong, 2008; Ben Delwiche, Ormat Technologies Inc., written commun., 2012). Tertiary sediments are grouped separately from unconsolidated Quaternary basin fill sediments because typically they are more fine-grained and less permeable (Maurer and others, 2004, p. 7). The hydraulic conductivity of Tertiary sedimentary rocks and sediments can range from $2 \times 10^{-4}$ to $20 \mathrm{ft} / \mathrm{d}$ (Maurer and others, 2004, table 2).

\section{Basin-Fill Deposits}

Basin-fill deposits in Dixie Valley are composed of heterogeneous mixtures of gravel, sand, silt, and clay sediments that have been eroded from the surrounding mountain ranges and deposited on the basin floor. Younger and older basin-fill deposits of Quaternary age were mapped previously by Willden and Speed (1974, pl. 1). Because fresh, basin-fill aquifers in Dixie Valley are present in younger and older deposits, no distinction will be made between these two units in this report and both will be referred to as "basin fill."
Basin-fill deposits cover 48 percent (about $627 \mathrm{mi}^{2}$ ) of the basin-floor surface area and extend to varying depths (Maurer and others, 2004). Gravity profiles, which are composed of individual gravity measurements made by a gravimeter, indicate that basin-fill deposits generally are shallow near the mountain fronts, becoming thick near the basin center (Schaefer, 1983; Mankhemthong and others, 2008). Profiles also show several deep sub-basins along the basin center, with maximum depths of as much as 10,000 ft bls (fig. 2; Schaefer, 1983).

\section{Playa Deposits}

A series of lakes covered much of northwestern Nevada during the Pleistocene Epoch (Morrison, 1964; Reheis, 1999) and Lake Dixie occupied Dixie Valley. Lake Dixie, has since evaporated, leaving behind thick Quaternary lake-bottom sediments constituting the modern playa (fig. 2). Playa deposits are composed mostly of clay and silt (Soil Survey Staff, 2012), cover 5 percent $\left(68 \mathrm{mi}^{2}\right)$ of the basin-floor surface area, and extend to an unknown depth. Shallow well logs from the southern (Nevada Division of Water Resources well log number 108770) and northern (Nevada Division of Water Resources well log number 61383) playa areas noted the persistence of lacustrine clay to depths of 50 and $500 \mathrm{ft}$ bls, respectively, which are synonymous with total drilled depth. Deeper geothermal well logs document that lacustrine clay persists to about 1,450 ft bls near the west-central edge of the playa (Ben Delwiche, Ormat Technologies Inc., written commun., 2012) and to about 2,700 ft bls near the northern edge of the playa (Bernard Raemy, Terra-Gen Power, LLC, written commun., 2012) (ig. 2).

The playa-basin fill interface likely is composed of interfingered deposits (fig. 3). Clay and basin-fill interfingering is supported by many flowing artesian wells (each to differing degrees) clustered just south of the playa (fig. 4; table 3 , wells 30-44, 46). Drillers' logs indicate that subsurface sediments adjacent to most of the flowing-artesian wells in this area are composed of alternating gravel and sand layers beneath or between interfingered clay lenses that create semi-confined conditions.

The hydraulic conductivity of shallow playa deposits adjacent to well 27 was estimated at about $6.5 \times 10^{-4} \mathrm{ft} / \mathrm{d}$ from a slug test (fig. 5; U.S. Geological Survey, 2010). Well 27 penetrates about $9.6 \mathrm{ft}$ of playa deposits and is screened from about 5.6 to $9.6 \mathrm{ft}$ bls (table 4). Because the well was pumped dry, only water-level recovery data were used for the slug-test analysis. Hydraulic conductivity was estimated using an Excel ${ }^{\circledR}$ spreadsheet program (Halford and Kuniansky, 2002) that uses the Bouwer and Rice (1976) method. A transmissivity estimate of $0.10 \mathrm{ft}^{2} / \mathrm{d}$ was calculated by multiplying the hydraulic conductivity by an assumed aquifer thickness of $200 \mathrm{ft}$ (table 4). Although the playa clay is much thicker, the upper $200 \mathrm{ft}$ was assumed to be the active part of the playa aquifer where groundwater flow is likely to occur. 


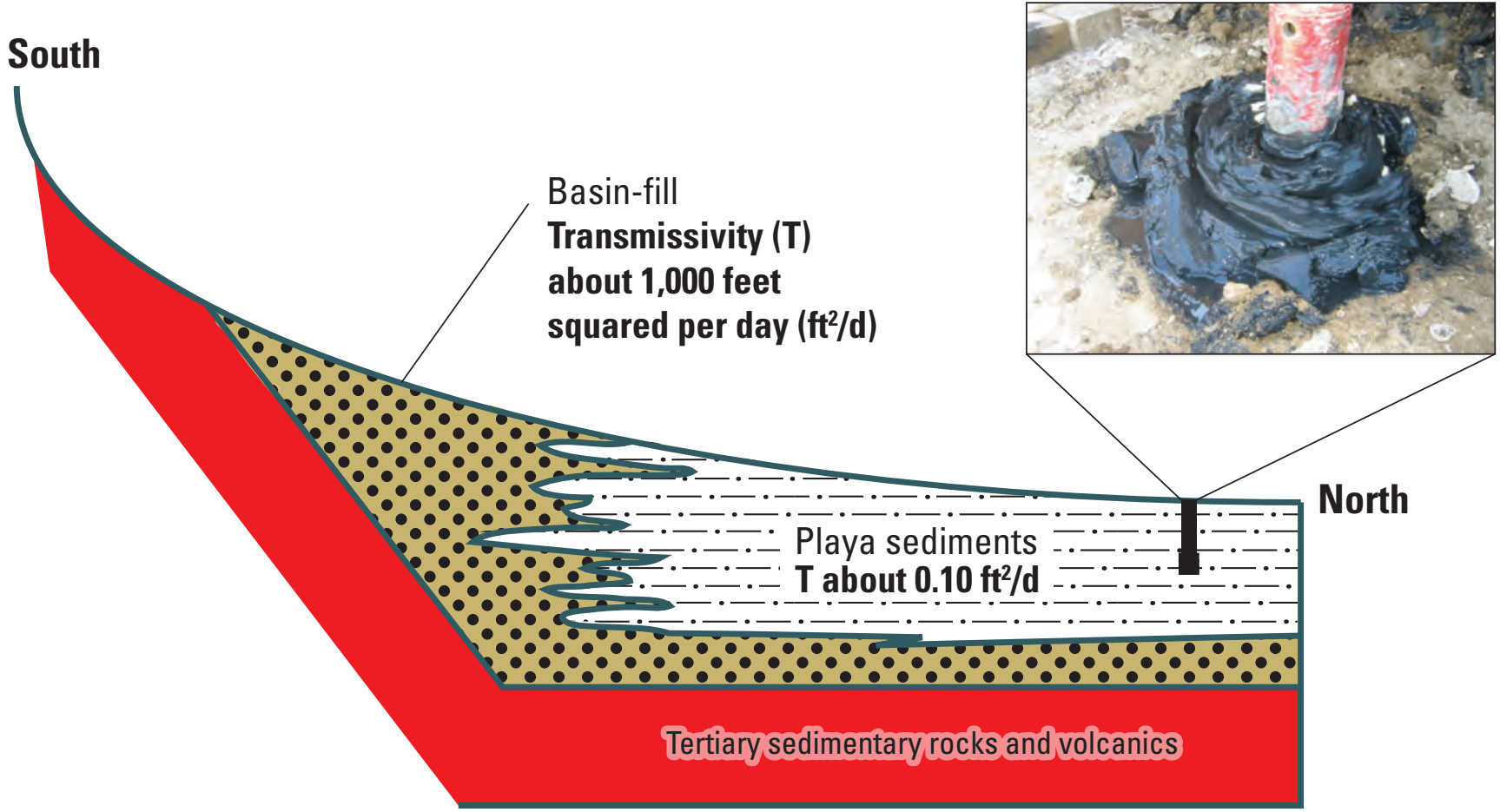

Figure 3. Conceptual cross-sectional diagram showing inter-fingering of clay-dominated playa and basin-fill sediments, and photograph showing typical playa-deposits during well drilling in Dixie Valley, west-central Nevada. Photograph associated with Nevada Division of Water Resources well log number 108770.

\section{Structural Features}

Faults can be important features in controlling groundwater flow. A fault can facilitate groundwater flow by acting as a conduit or preferential flow path, or it can impede groundwater flow where hydrogeologic units of differing hydraulic conductivity become juxtaposed (Plume, 2009, p. 12). Quaternary fault locations in Dixie Valley (Great Basin Center for Geothermal Energy, 2004) are shown in figure 5.

Dixie Valley is bounded on the east and west sides by normal faults (Great Basin Center for Geothermal Energy, 2004). The main range-bounding fault is the Stillwater Fault (fig. 5), which is still active and is at the base of the Stillwater Range along with a series of smaller subsidiary faults not visible at the land surface (Schaefer, 1983, p. 11; Smith and others, 2001). A severe earthquake occurred along the Stillwater Range in 1954, creating scarps of $10 \mathrm{ft}$ on average on the west side of Dixie Valley (Romney, 1957). The valley floor became down-tilted to the west and sediments were thought to compact as a result of the earthquake ground movement (Zones, 1957, p. 395). This sediment compaction caused water levels to rise temporarily (by less than 1 to as much as $4.6 \mathrm{ft}$ ) in wells south of the playa and caused spring discharge to increase south of the playa and along the western basin margin (Zones, 1957, p. 395-396).

Several geothermal studies have mapped and characterized faults in Dixie Valley smaller in scale than the Stillwater Fault; however, the extent to which basinfill groundwater flow is affected locally by these faults is mostly unknown. Linear spring alignment, as well as scarps, fissures, and distinctive vegetation patterns, have been used to identify fault locations in the valley (Smith and others, 2001). There are 46 documented springs in Dixie Valley (fig. 5; table 5), 17 of which are within about $0.2 \mathrm{mi}$ of a Quaternary fault. Of these 17 springs, 10 have been measured for water temperature. Cold water temperatures (less than $20^{\circ} \mathrm{C}$ ) were measured in four of the fault-adjacent springs, and warm temperatures (between 20 and $50^{\circ} \mathrm{C}$ ) were measured in five of these springs. Spring water temperatures greater than $20^{\circ} \mathrm{C}$ likely suggest geothermal mixing (see section, "Connection Between Basin-Fill and Geothermal Aquifers"). The remaining spring, Dixie Valley Hot Springs (S28, table 5; fig. 5), was hot (greater than $50^{\circ} \mathrm{C}$ ). Although many fault-adjacent springs were warm-to-hot, faults generally do not act as significant conduits for transporting geothermal water to land surface. 


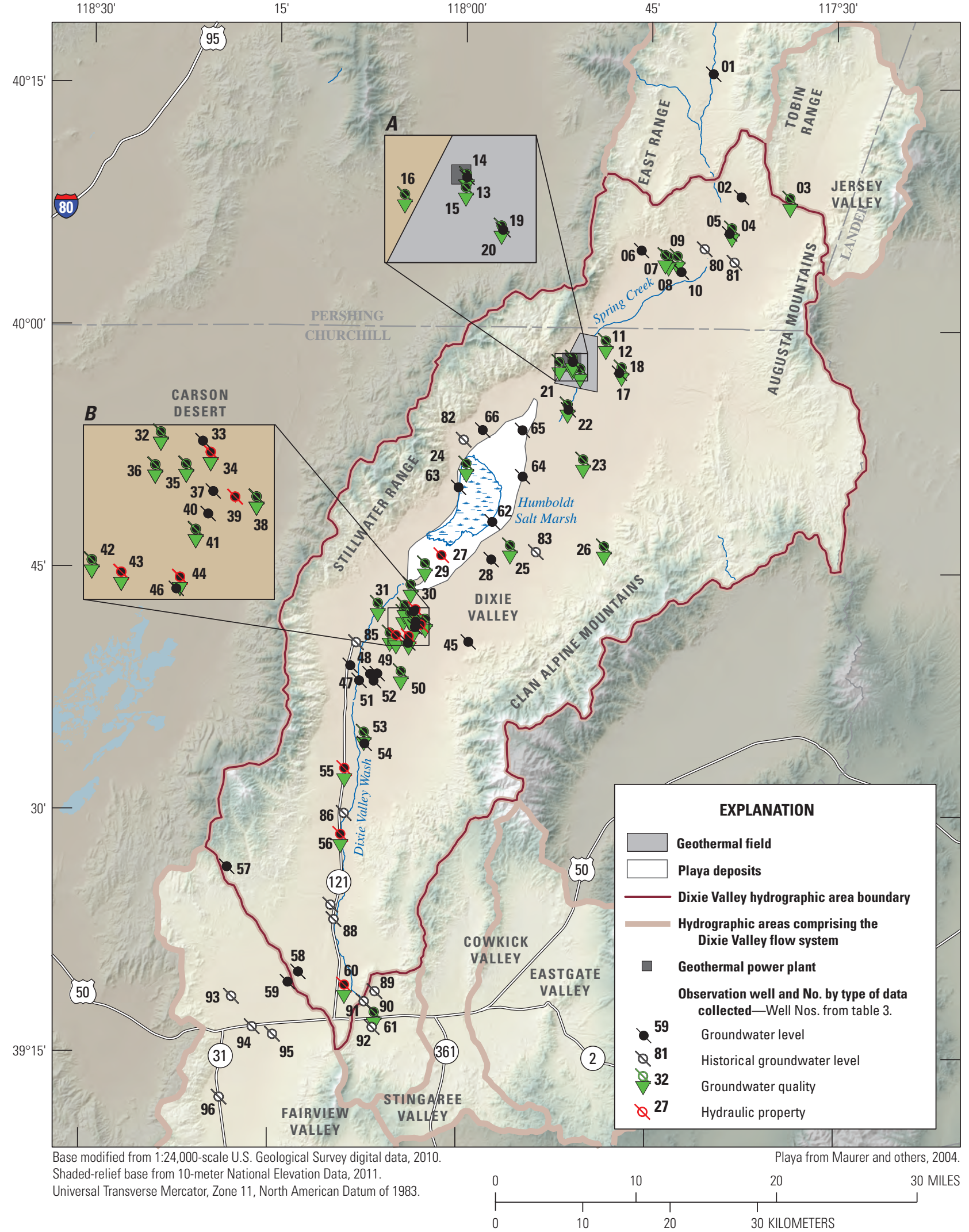

Figure 4. Data collection sites in Dixie Valley, west-central Nevada, 2009-11. Types of data collected include groundwater level (WL), historical groundwater level (HWL), groundwater quality (OW), and hydraulic properties (HP). 




Figure 5. Estimates of basin-fill transmissivity from single-well aquifer tests or specific-capacity calculations and water-temperature distributions in springs, Dixie Valley, west-central Nevada. 


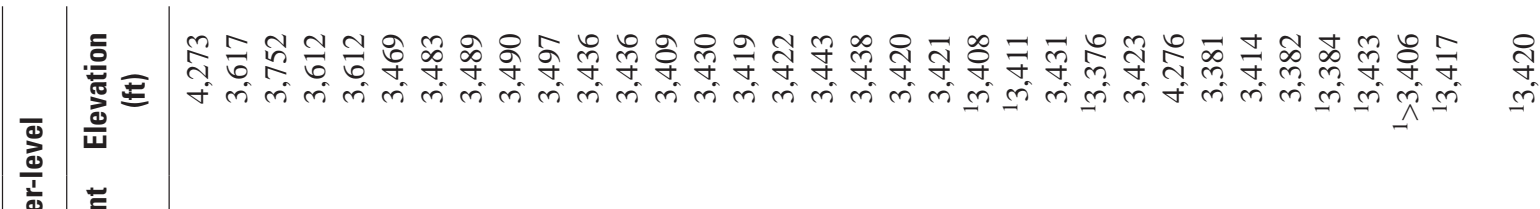

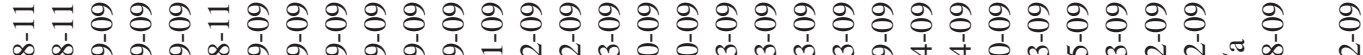

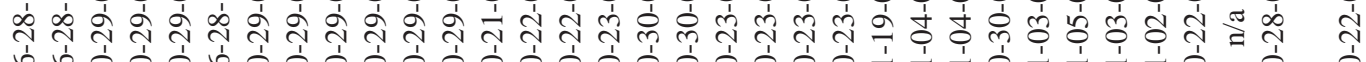

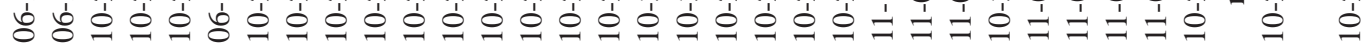

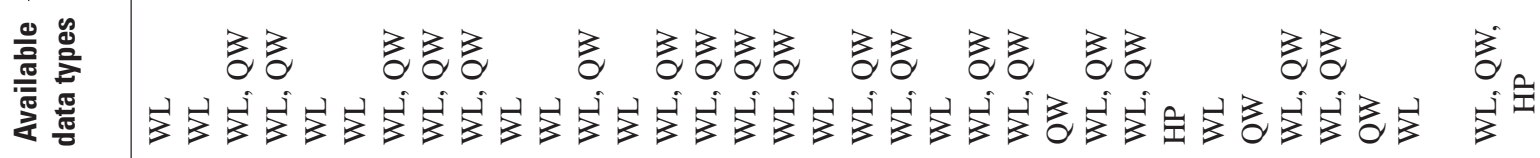

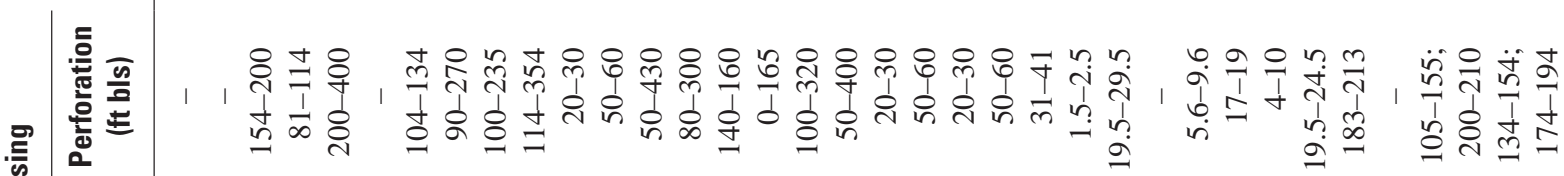

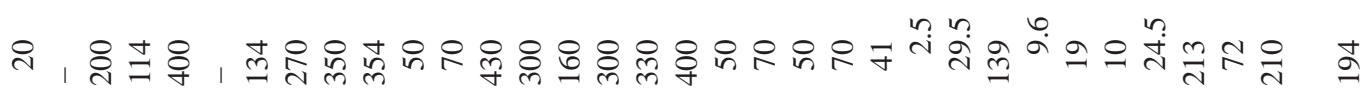

ஜ 粚 突

ๆ

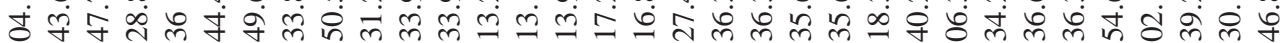

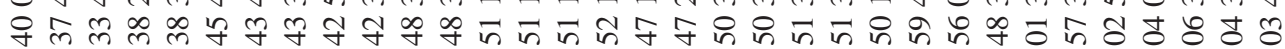

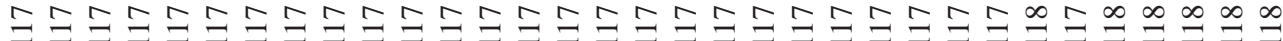
$\exists \exists \exists \exists \exists \exists \exists \exists \exists \exists \exists \exists \exists \exists \exists \exists \exists \exists \exists \exists \exists \exists \exists \exists \exists \exists \exists \exists \exists \exists \exists$

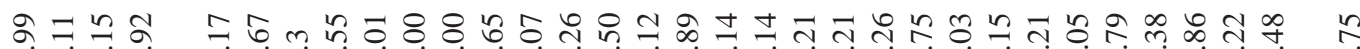

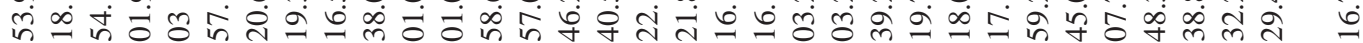

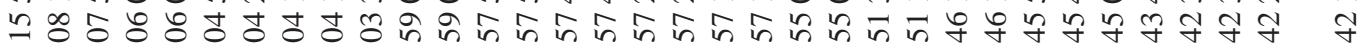

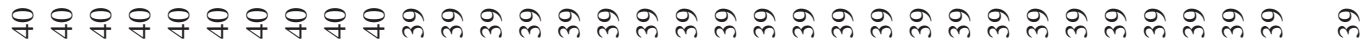

₹

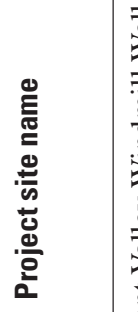

$\overline{3}$

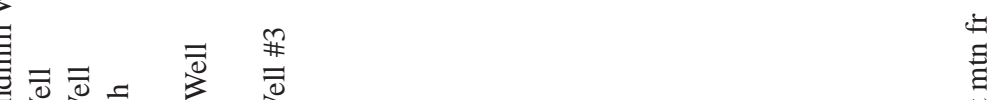

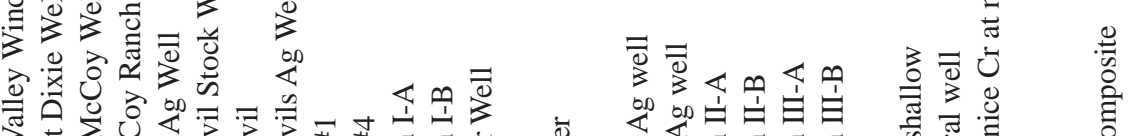

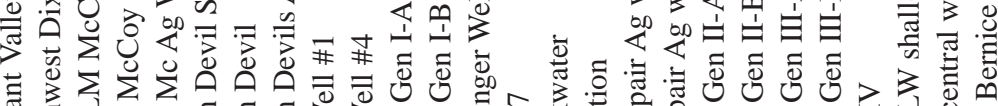

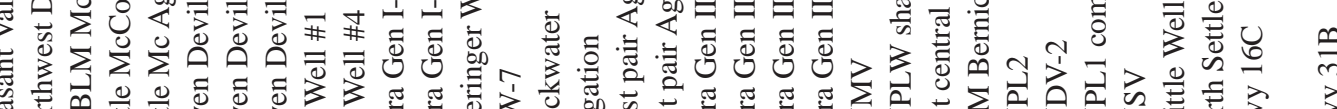

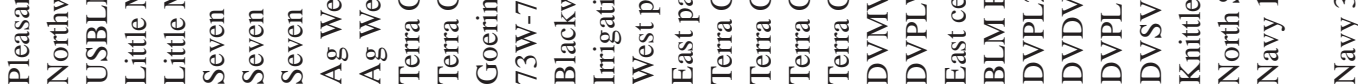

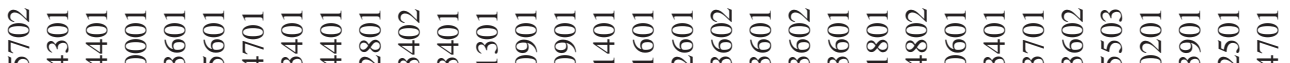
?

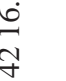




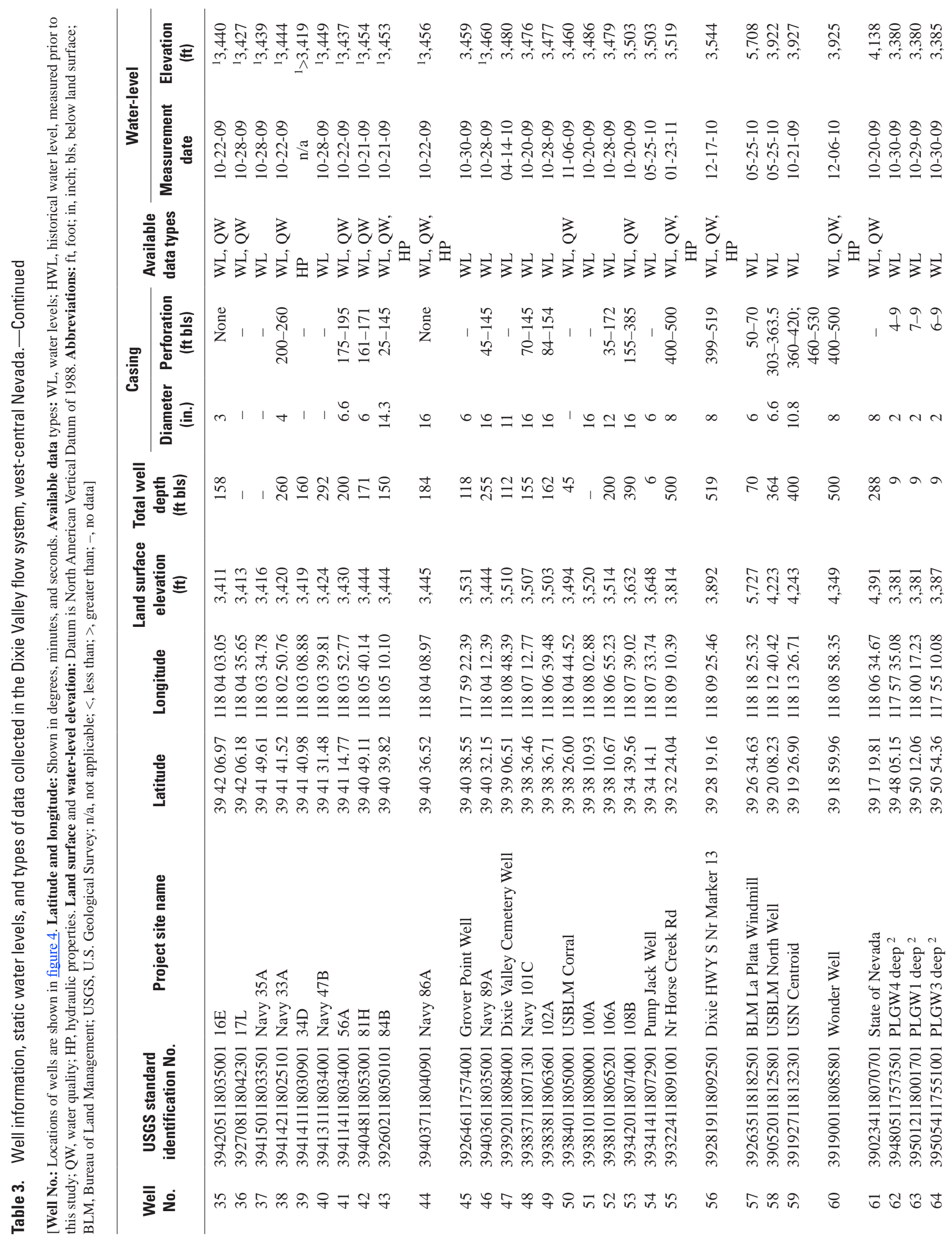




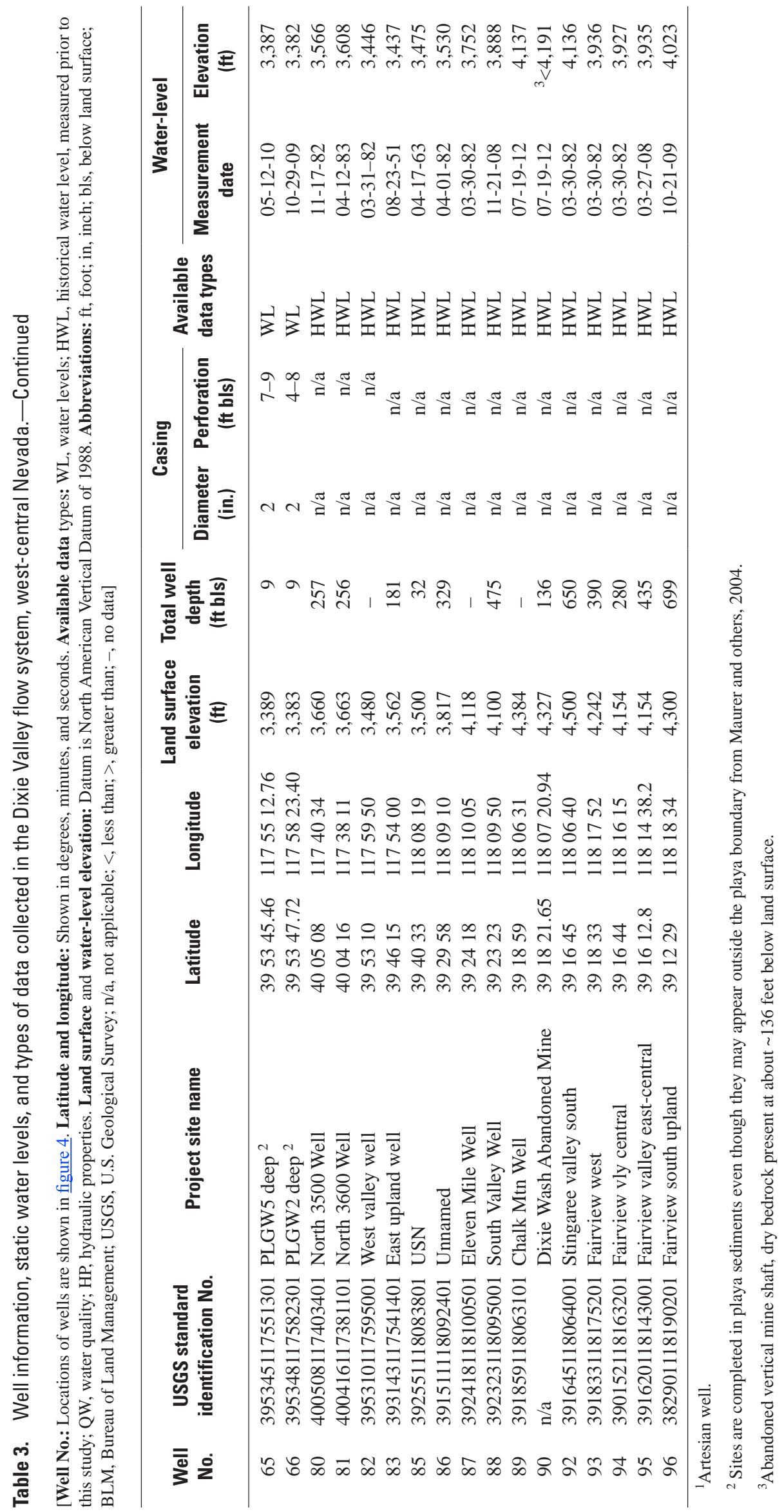


Table 4. Basin-fill transmissivity estimated from single-well and multiple-well aquifer tests, specific-capacity estimates, slug tests, and well characteristics, Dixie Valley, west-central Nevada.

[Well No.: Locations of wells are shown in figure 5. NDW R well log: Can be viewed by searching for log number at: http://water.nv.gov/data/welllog/. Colors correspond to transmissivity estimates from figure 5. Land surface, total well depth, screened interval, and water levels are referenced to North American Vertical Datum of 1988 (NAVD 88); data from National Elevation Dateset (http://ned.usgs.gov/). Flow rate: Values shown for multiple-well aquifer tests and single-well aquifer tests in flowing wells. Abbreviations: NDWR, Nevada Division of Water Resources; ft bls, foot below land surface; gal/min, gallon per minute; $\mathrm{ft}^{2} / \mathrm{d}$, foot squared per day; >, greater than; n/a, not applicable; -, no data]

\begin{tabular}{|c|c|c|c|c|c|c|c|c|}
\hline $\begin{array}{l}\text { Well } \\
\text { No. }\end{array}$ & $\begin{array}{c}\text { NDWR well } \\
\log \text { No. }\end{array}$ & $\begin{array}{c}\text { Land surface } \\
\text { elevation } \\
\text { (ft) }\end{array}$ & $\begin{array}{c}\text { Total well } \\
\text { depth elevation } \\
\text { (ft) }\end{array}$ & $\begin{array}{c}\text { Screened } \\
\text { interval } \\
\text { elevation (ft) }\end{array}$ & $\begin{array}{c}\text { Static } \\
\text { water level } \\
\text { elevation (ft) }\end{array}$ & Date of test & $\begin{array}{l}\text { Flow rate } \\
\text { (gal/min) }\end{array}$ & $\begin{array}{c}\text { Transmissivity } \\
\left(\mathrm{ft}^{2} / \mathrm{d}\right)\end{array}$ \\
\hline \multicolumn{9}{|c|}{ Transmissivity from multiple-well aquifer testing } \\
\hline 08 & 12565 & 3,580 & 3,310 & $3,490-3,310$ & 3,485 & 4-24 to $5-21-2012$ & $\mathrm{n} / \mathrm{a}$ & ${ }^{1} 10,400$ \\
\hline 13 & 11047 & 3,471 & 3,041 & $3,421-3,041$ & 3,411 & $2-28$ to $2-29-2012$ & $\mathrm{n} / \mathrm{a}$ & ${ }^{1} 14,800$ \\
\hline 15 & 12750 & 3,468 & 3,308 & $3,328-3,308$ & 3,416 & $2-28$ to $2-29-2012$ & $\mathrm{n} / \mathrm{a}$ & ${ }^{1} 16,900$ \\
\hline 56 & 113029 & 3,892 & 3,373 & $3,493-3,373$ & 3,546 & 5-2 to 5-27-2011 & $\mathrm{n} / \mathrm{a}$ & 700 \\
\hline 60 & 112591 & 4,349 & 3,849 & 3,949-3,849 & 3,917 & 5-16 to $5-19-2011$ & $\mathrm{n} / \mathrm{a}$ & 2,500 \\
\hline 55 & 113028 & 3,814 & 3,314 & $3,414-3,314$ & 3,021 & 7-5 to 7-7-2012 & $\mathrm{n} / \mathrm{a}$ & 6,000 \\
\hline \multicolumn{9}{|c|}{ Transmissivity from single-well aquifer testing in flowing wells } \\
\hline 31 & 10240 & 3,413 & 3,200 & $3,230-3,200$ & $>3,413$ & 5-17 to 5-18-2012 & 35 & 1800 \\
\hline \multicolumn{9}{|c|}{ Transmissivity from single-well slug testing } \\
\hline 27 & 109435 & 3,382 & 3,372 & $3,376-3,372$ & 3,381 & $7-13$ to $7-15-2011$ & $\mathrm{n} / \mathrm{a}$ & ${ }^{2} 0.10$ \\
\hline \multicolumn{9}{|c|}{ Transmissivity from drillers' log specific capacity } \\
\hline $\mathrm{n} / \mathrm{a}$ & 25053 & 5,283 & 4,965 & $5,009-4,969$ & 5,272 & 08-19-1983 & 0.2 & 30 \\
\hline $\mathrm{n} / \mathrm{a}$ & 15546 & 4,168 & 3,686 & $3,903-3,763$ & 3,956 & 04-18-1976 & 0.23 & 30 \\
\hline $\mathrm{n} / \mathrm{a}$ & 21433 & 3,343 & 3,078 & $3,228-3,078$ & 3,323 & 07-05-1980 & 0.63 & 100 \\
\hline $\mathrm{n} / \mathrm{a}$ & 11940 & 3,433 & 3,270 & $3,390-3,270$ & - & 02-04-1971 & 0.71 & 110 \\
\hline $\mathrm{n} / \mathrm{a}$ & 68779 & 3,611 & 3,111 & $3,271-3,111$ & 3,461 & 08-06-1997 & 1.33 & 240 \\
\hline $\mathrm{n} / \mathrm{a}$ & 7120 & 4,286 & 4,086 & 4,136-4,086 & - & 03-15-1963 & 2.78 & 560 \\
\hline $\mathrm{n} / \mathrm{a}$ & 9222 & 3,657 & 3,418 & $3,574-3,424$ & 3,593 & 01-15-1965 & 23.68 & 6,700 \\
\hline $\mathrm{n} / \mathrm{a}$ & 7042 & 3,510 & 3,255 & $3,450-3,255$ & 3,475 & 02-17-1963 & 24.5 & 7,000 \\
\hline $\mathrm{n} / \mathrm{a}$ & 9668 & 3,447 & 3,312 & $3,402-3,312$ & 3,412 & 07-22-1967 & 25 & 7,100 \\
\hline $\mathrm{n} / \mathrm{a}$ & 88630 & 3,462 & 3,162 & $3,382-3,162$ & 3,403 & $11-20-2002$ & 28.33 & 8,200 \\
\hline $\mathrm{n} / \mathrm{a}$ & 10455 & 3,447 & 3,199 & $3,410-3,208$ & 3,410 & 01-17-1969 & 30.3 & 8,900 \\
\hline $\mathrm{n} / \mathrm{a}$ & 12125 & 3,654 & 3,304 & $3,594-3,304$ & 3,589 & 02-19-1972 & 47.78 & 15,000 \\
\hline $\mathrm{n} / \mathrm{a}$ & 9623 & 3,499 & 3,224 & $3,399-3,234$ & 3,481 & 06-29-1967 & 51.47 & 16,400 \\
\hline $\mathrm{n} / \mathrm{a}$ & 9221 & 3,671 & 3,433 & $3,556-3,437$ & 3,621 & 04-19-1965 & 54.46 & 17,600 \\
\hline $\mathrm{n} / \mathrm{a}$ & 9621 & 3,592 & 3,347 & $3,492-3,357$ & 3,500 & 07-29-1966 & 58.33 & 19,000 \\
\hline $\mathrm{n} / \mathrm{a}$ & 9619 & 3,472 & 3,142 & 3,372-3,172 & 3,427 & 05-17-1967 & 100 & 35,500 \\
\hline $\mathrm{n} / \mathrm{a}$ & 9618 & 3,487 & 3,157 & $3,387-3,167$ & 3,442 & 06-11-1967 & 121.0 & 44,300 \\
\hline $\mathrm{n} / \mathrm{a}$ & 9331 & 3,580 & 3,335 & $3,480-3,340$ & 3,488 & 07-20-1966 & 123.81 & 45,500 \\
\hline \multicolumn{8}{|c|}{ Average (excluding playa) } & 8,700 \\
\hline
\end{tabular}

${ }^{1}$ Transmissivity value based on aquifer test by Interflow Hydrology, Inc. and Mahannah and Associates, LLC.

${ }^{2}$ Sites are completed in playa sediments even though they may appear outside the playa sediment boundary by Maurer and others (2004) depicted in figure 4. 
Table 5. Locations, elevations, and temperatures in springs and Quaternary faults in the Dixie Valley flow system, west-central Nevada.

[Site No.: Locations of sites are shown in figure 5. L atitude and longitude: Shown in degrees, minutes, seconds. Spring elevation: In feet above North American Vertical Datum of 1988 (NAVD 88). Abbreviations: ${ }^{\circ} \mathrm{C}$, degrees Celsius; ft, foot; USGS, U.S. Geological Survey; -, no data]

\begin{tabular}{|c|c|c|c|c|c|c|}
\hline $\begin{array}{l}\text { Site } \\
\text { No. }\end{array}$ & $\begin{array}{c}\text { USGS standard } \\
\text { identification No. }\end{array}$ & Project site name & Latitude & Longitude & $\begin{array}{c}\text { Elevation } \\
\text { (ft) }\end{array}$ & $\begin{array}{c}\text { Temperature } \\
\left({ }^{\circ} \mathrm{C}\right)\end{array}$ \\
\hline S1 & 392704118185201 & La Plata Spring & 392703.93 & 1181852.46 & 5,940 & 7.8 \\
\hline $\mathrm{S} 2$ & 392758118171601 & Burnt Cabin Spring & 392757.78 & 1181715.61 & 5,920 & 8 \\
\hline S3 & 393119118005001 & Horse Ck Ranch Spg & 393119.47 & 1180049.59 & 5,194 & 13.8 \\
\hline S4 & 393219118162001 & Spring & 393218.87 & 1181620.09 & 6,630 & 9.5 \\
\hline S5 & 393431117562101 & Spring & 393430.85 & 1175621.23 & 7,600 & 7.1 \\
\hline S8 & 393755118103901 & Willow Spring & 393754.95 & 1181039.38 & 3,963 & 15.3 \\
\hline S9 & 393808118104601 & Mud Spring & 393808.28 & 1181046.32 & 4,006 & - \\
\hline S10 & 393911118113601 & Spring & 393911.27 & 1181136.45 & 4,320 & 7.7 \\
\hline S11 & 394000118020101 & Eastern Settlement spring & 394000.43 & 1180201.33 & 3,471 & 6.9 \\
\hline S12 & 394111118062801 & Spring & 394111.14 & 1180627.7 & 3,438 & - \\
\hline S17 & 394317117485001 & Spring & 394316.51 & 1174849.53 & 5,560 & 11.6 \\
\hline S18 & 394515117595201 & Southeast playa spring & 394514.89 & 1175952.12 & 3,386 & 10.3 \\
\hline S19 & 394537117470101 & Spring & 394536.75 & 1174701.34 & 4,910 & 12.3 \\
\hline S20 & 395429117591501 & PW spring & 395428.54 & 1175915.35 & 3,399 & 22.4 \\
\hline S21 & 394547118052001 & Spring & 394546.93 & 1180519.72 & 3,416 & - \\
\hline S22 & 394601117584101 & Buckbrush Spring & 394601.26 & 1175841.32 & 3,389 & 18.6 \\
\hline S23 & 394631118043301 & Cold Spring & 394631.31 & 1180432.83 & 3,425 & 29 \\
\hline S24 & 394749117402101 & Spring & 394748.53 & 1174020.89 & 5,120 & 28.8 \\
\hline S25 & 394813118031101 & Northern meadows spring & 394813.09 & 1180310.94 & 3,425 & 26 \\
\hline S26 & 394900118003801 & Seep & 394900 & 1180037.89 & 3,386 & - \\
\hline S27 & 395034117423201 & Spring & 395033.93 & 1174232.19 & 4,370 & - \\
\hline S36 & 400227117376001 & Spring & 400227.18 & 1173759.57 & 3,685 & - \\
\hline S37 & 400341117373201 & Spring & 400341.33 & 1173732.02 & 3,668 & - \\
\hline S38 & 400447117361301 & S-92 Springs & 400447 & 1173613 & 3,728 & - \\
\hline S39 & 400448117361301 & McCoy Spring & 400448 & 1173613 & 3,725 & 44.8 \\
\hline S40 & 400452117355001 & Spring & 400421 & 1173555 & 3,760 & - \\
\hline S41 & 400452117355002 & Spring & 400452 & 1173550 & 3,760 & - \\
\hline S42 & 400452118481701 & Spring & 400452.27 & 1174816.89 & 4,669 & - \\
\hline S43 & 400507117483301 & Spring & 400507.19 & 1174833.4 & 4,823 & - \\
\hline S44 & 400517117430801 & Sow Spring & 400454 & 1174316 & 3,780 & - \\
\hline S45 & 400517117432801 & Seven Devil Hot spring & 400517 & 1174328 & 3,700 & 62.1 \\
\hline S46 & 400524117432401 & Spring & 400524 & 1174324 & 3,752 & - \\
\hline
\end{tabular}




\section{Hydrogeology}

The Dixie Valley flow system is hydrologically closed. In Dixie Valley, the terminus of the flow system, most groundwater, surface water, and precipitation that enter the basin remain there until naturally discharged by springs or evapotranspiration. Limited groundwater pumping for agriculture, stock watering, and geothermal supplementation also occurs in the valley. Groundwater in basin-fill deposits of Dixie Valley is present mostly under unconfined conditions. Discontinuous confined groundwater conditions are present along the perimeter of the playa where lacustrine clay and basin-fill deposits are inter-fingered (fig. 3), most notably just south of the playa, but also north of the playa (table 3 , wells 21 and 22).

\section{Aquifer Properties}

Hydraulic conductivity of basin-fill deposits generally grades from higher values along the mountain front to lower values near the basin center. As sediments are eroded from mountain ranges and deposited in the valley, coarsegrained sediments generally filter out and deposit along alluvial fans and finer-grained material is deposited in the center of the basin (Plume, 1996, p. B15-B17). Hydraulic conductivity of basin-fill deposits can vary by many orders of magnitude $\left(2 \times 10^{-4}\right.$ to $\left.2,200 \mathrm{ft} / \mathrm{d}\right)$, depending on the location and composition of the deposits in the basin (Maurer and others, 2004).

Hydraulic properties of the basin fill were characterized by transmissivity estimated from single- and multiple-well aquifer tests and specific-capacity data (ig. 5; table 4). Reliable estimates of transmissivity can be made using single-well aquifer tests, even when the aquifer thickness is not well known (Halford and others, 2006, p. 469). Single-well aquifer tests were completed in three non-flowing wells (55, 56, and 60) in southern Dixie Valley and in four flowing wells (34, 39, 43, and 44) in south-central Dixie Valley south of the playa (table 4; fig. 5). Drawdown data from each test were analyzed using an Excel ${ }^{\circledR}$ spreadsheet program (Halford and Kuniansky, 2002) using the Cooper and Jacob (1946) method for non-flowing wells and the Jacob and Lohman (1952) method for flowing wells.

Transmissivity estimates from the non-flowing wells in southern Dixie Valley ranged from 700 to $6,000 \mathrm{ft}^{2} / \mathrm{d}$ with an average of about 3,100 ft²/d (table 4; U.S. Geological Survey, 2010). These wells have a depth of about $500 \mathrm{ft}$ and are screened across at least $100 \mathrm{ft}$ of unconfined basin-fill aquifer. The low transmissivity of $700 \mathrm{ft}^{2} / \mathrm{d}$ estimated at well 56 represents a screened interval composed predominantly of gravel, with 5-10 percent clay. The high transmissivity value of $6,000 \mathrm{ft}^{2} / \mathrm{d}$ estimated at well 55 represents a screened interval of clean gravels and sand. Transmissivity estimates from five flowing wells ranged from 400 to 1,400 ft²/d (table 4; U.S. Geological Survey, 2010; Interflow
Hydrology, Inc., and Mahannah and Associates, LLC, 2012b). These wells penetrate similar depths (less than $200 \mathrm{ft}$ ) and are generally open to more than $60 \mathrm{ft}$ of basin-fill material consisting of alternating mixtures of sand, gravel, and clay. Additional multiple well tests were completed in northern Dixie Valley (table 4, wells 08, 13, and 15) (Interflow Hydrology, Inc., and Mahannah and Associates, LLC, 2012b). The test results indicate transmissivity ranges from 10,400 to $16,900 \mathrm{ft}^{2} / \mathrm{d}$ in northern Dixie Valley (wells 08, 13, and 15; table 4).

The specific capacity of a well, which commonly is included on the well drillers' log, is often used to estimate transmissivity when aquifer test data are sparse (Lohman and others, 1972, p. 52). Where specific-capacity data were available, an empirical log-based regression equation that relates specific capacity to transmissivity was used to estimate transmissivity (Maurer, 2011, p. 25). Transmissivities ranging from 30 to $45,500 \mathrm{ft}^{2} / \mathrm{d}$ were estimated for 25 wells using specific-capacity data (fig. 5; table 4). Transmissivity estimates derived from aquifer tests generally are more accurate and reliable than those derived from specific-capacity data. Because aquifer test data were not available to validate specific-capacity-derived transmissivity estimates for the same well, these estimates should be considered only as an approximation of transmissivity. However, transmissivity estimated from well driller's log 11940 south of the playa $\left(110 \mathrm{ft}^{2} / \mathrm{d}\right)$ was within the same order of magnitude of transmissivity estimated from a flowing well test from well 39 (driller's $\log 11083 ; 900 \mathrm{ft}^{2} / \mathrm{d}$ ), $1.4 \mathrm{mi}$ to the west of 11940 (table 4; fig. 5). In some areas of Dixie Valley, specific-capacity-derived transmissivity estimates varied by one or more orders of magnitude among wells with similar construction and near each other. For example, in the northern part of Dixie Valley (fig. 5, box A), transmissivity estimates from four wells within $1 \mathrm{mi}$ of each other ranged from 4,500 to 45,500 ft²/d (well log numbers 12565, 9620, 9621, and 9331 from table 4). These transmissivity differences were primarily controlled by differing amounts of fine-grained material in the formation adjacent to screened intervals.

Overall, basin-fill transmissivity estimates from Dixie Valley averaged $8,700 \mathrm{ft}^{2} / \mathrm{d}$ (table 4, north and south of the playa averaged about 11,000 and 5,400 ft ${ }^{2} / \mathrm{d}$, respectively), and are within the range of basin-fill estimates determined across the State of Nevada. Basin-fill transmissivity estimates from 106 aquifer and slug tests completed throughout Nevada ranged from 20 to $90,000 \mathrm{ft}^{2} / \mathrm{d}$ and averaged 8,600 ft'/d (U.S. Geological Survey, 2010).

\section{Occurrence and Movement of Groundwater in Basin-Fill Deposits}

The occurrence and movement of groundwater in Dixie Valley is interpreted using a potentiometric water-surface map (pl. 1). The potentiometric map represents the elevation to which water will rise in a well casing (Lohman and others, 
1972). In many instances, the water table is the potentiometric water level. When wells are screened in confining units, such as silts and clays, the potentiometric water level may rise above the depth at which groundwater is present in the aquifer in response to pressures beneath confining units. Potentiometric surface contours were developed from depthto-water measurements and land-surface elevation from 54 wells within or near the boundary of the Dixie Valley study area (table 3; pl. 1). Most depth-to-water measurements were made during autumn 2009 by USGS personnel and Mahannah and Associates, LLC; additional wells were measured between winter 2010 and summer 2011 as permissions were granted and new wells were drilled. Depths to groundwater range from nearly $30 \mathrm{ft}$ above land surface just south of the playa (artesian conditions, well 35) to more than $400 \mathrm{ft}$ bls in the southernmost part of the valley (well 60). Some wells south of the playa penetrate both the water-table aquifer and one or more confined aquifers within the upper $250 \mathrm{ft}$ of alternating gravel and clay; therefore, some water levels could represent a composite groundwater elevation rather than the water table. The potentiometric surface map (pl. 1) represents a current (about 2009) potentiometric surface of the Dixie Valley groundwater system, which is mostly unconfined.

The potentiometric water-level elevation contours depict the top of the groundwater surface and indicate general directions of groundwater flow in Dixie Valley (pl. 1). Historical and current groundwater pumping in the basin seem to have minimally affected regional water level elevations and groundwater-flow paths. Historical water levels were used to help guide the position and shape of water-level elevation contours in areas where current data were limited (table 3; $\mathrm{pl} .1$ ). In addition to measurements made during this study, 14 wells, 26 springs and 1 abandoned vertical mine shaft with historical water-level measurements from 1951 to 2009 were used to guide the construction of contour lines (table 3; pl. 1).

Groundwater generally moves radially from the mountain-range uplands toward the central valley lowlands, and eventually discharges near or along the playa edge (pl. 1). Groundwater flow generally is parallel with the topographic gradient from the southernmost and northernmost extents of the valley toward the playa. Flow patterns east and west of the playa indicate that groundwater is moving eastward from the Stillwater Range and westward from the Clan Alpine Mountains toward the playa. Harrill and Hines (1995, p. 10) hypothesized that the playa hydraulically separates groundwater north and south of Township 22N (pl. 1). The north-south and east-west trending flow patterns support this hypothesis and suggest that mixing between northern and southern groundwater systems in Dixie Valley likely is minimal.

Groundwater movement between the basin-fill aquifer and playa sediment is hydraulically constrained owing to physical and chemical differences between systems.
Groundwater flow in the playa and exchange with the basin-fill aquifer is physically limited because the playa sediment transmissivity is nearly 10,000 times less than that measured in the surrounding basin fill (table 4, well 27, screened in playa sediment), compared to the average of wells 34, 39, 43, and 44 (all screened in basin-fill). It should be noted this finding is based on a transmissivity estimate from a slug test from only one well screened down to 10 feet in depth in playa deposits, however playa sediments are assumed to become less transmissive with depth due to overburden pressure. Chemically, the groundwater interface between the basin fill and playa is analogous to coastal aquifers. Density contrasts between freshwater and saltwater systems in coastal aquifers suppress mixing (Barlow, 2003, p. 8-10). Groundwater density measurements were determined for many wells in this study using a standard equation that combines water temperature, total dissolved solids (TDS) concentration, and pressure. Basin-fill groundwater density averaged about $1.0 \mathrm{~g} / \mathrm{mL}$, whereas playa groundwater density averaged $1.16 \mathrm{~g} / \mathrm{mL}$ and ranged from 1.14 to $1.21 \mathrm{~g} / \mathrm{mL}$ (from sites 24, 27 , and 29). Concentrations of TDS in the playa groundwater range from about 184,000 to $310,000 \mathrm{mg} / \mathrm{L}$ (average 247,000 $\mathrm{mg} / \mathrm{L}$ from sites 24 and 29), which is 5-9 times greater than the TDS of seawater (about 35,000 mg/L). Playa groundwater TDS concentrations measured from well 62-66 ranged from 62,000 to 294,000 mg/L (average 212,000 mg/L; Mahannah and Associates, LLC, written commun., 2013). The high TDS of playa groundwater classifies it as a brine (Drever, 1982). Concentrations of TDS in the basin-fill aquifer ranges from 98 to 3,580 mg/L (average $637 \mathrm{mg} / \mathrm{L}$, determined from all wells except 24 and 29 [table 6]). A sharp TDS contrast of 683 and 184,000 mg/L is shown across less than $2 \mathrm{mi}$ separating well 30, located adjacent to the southern playa, and well 29 (fig. 4), in the southern playa, respectively. Substantial measured differences in transmissivity, density, and TDS between the basin fill and playa aquifer systems create an even sharper freshwater-saltwater interface than in coastal regions. Some groundwater exchange likely occurs between the basin fill and playa; however, this exchange occurs at substantially lower rates than groundwater flow within the basin-fill aquifer.

Fresh groundwater in closed-desert basins is known to discharge near playa edges (Toth, 1962; Duffy and Al-Hassan, 1988, p. 1678). In addition to numerous adjacent springs, the Dixie Valley playa is surrounded by phreatophytic vegetation on all sides. These phreatophytes, composed predominantly of greasewood (Sarcobatus vermiculatus [Hooker] Torrey), are sustained by groundwater and deep soil water (within about $60 \mathrm{ft}$ bls; Robinson, 1958) in addition to precipitation during the growing season. Discharge of groundwater by springs and phreatophytic vegetation surrounding the playa likely constitutes most fresh groundwater discharge from the flow system. Discharge upgradient from and along the edges of the playa provides additional evidence of minimal mixing between fresh groundwater and the playa brine. 


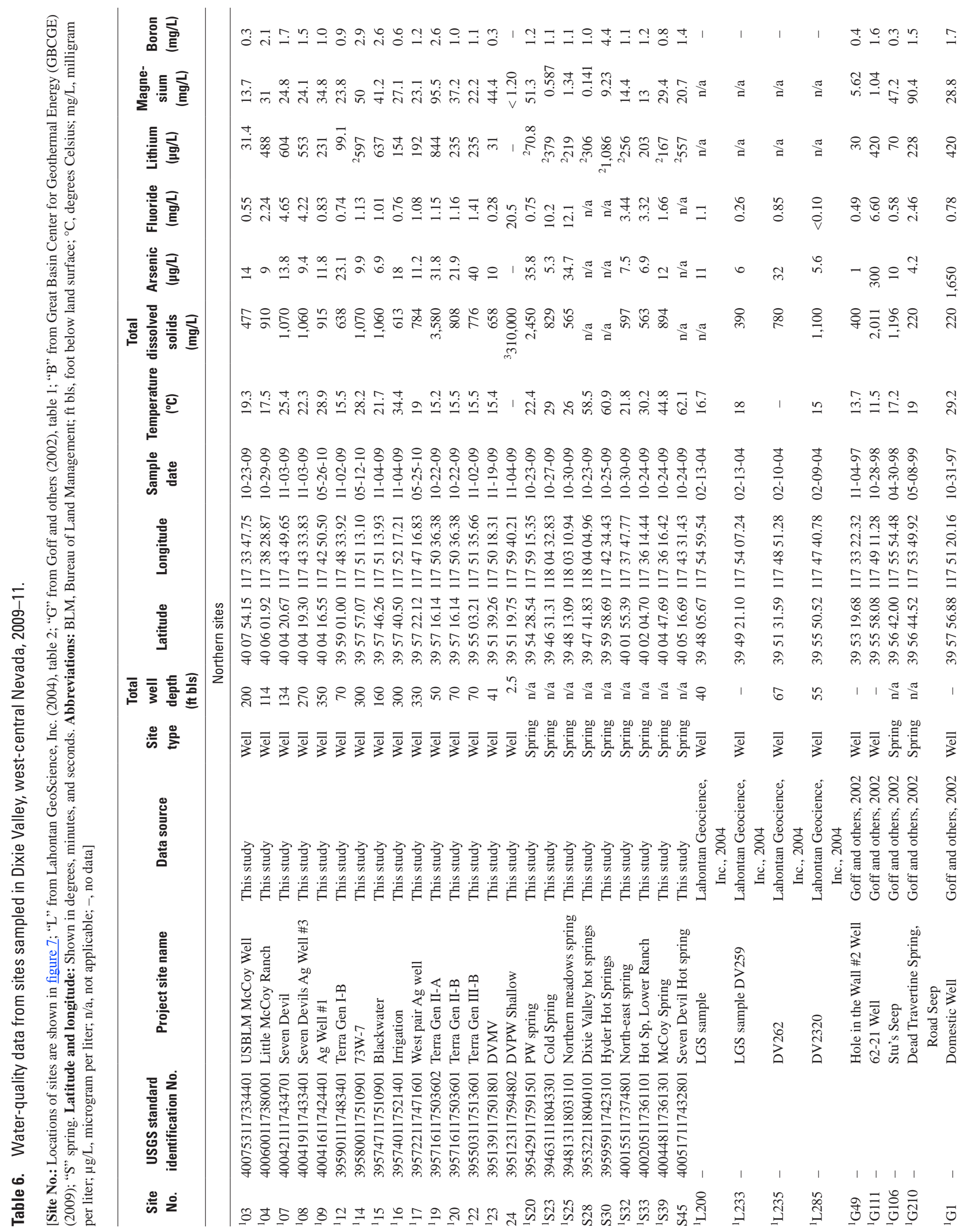




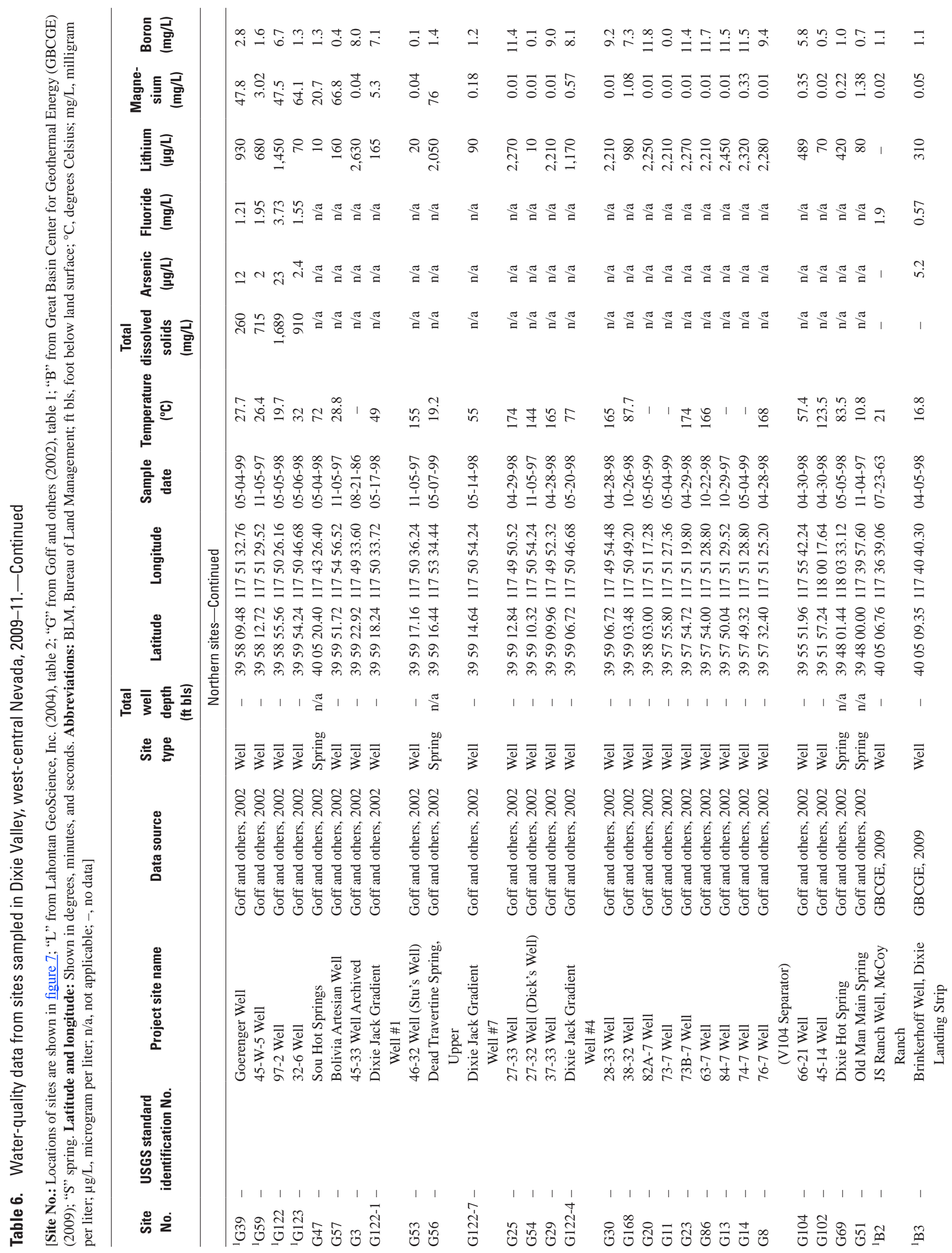




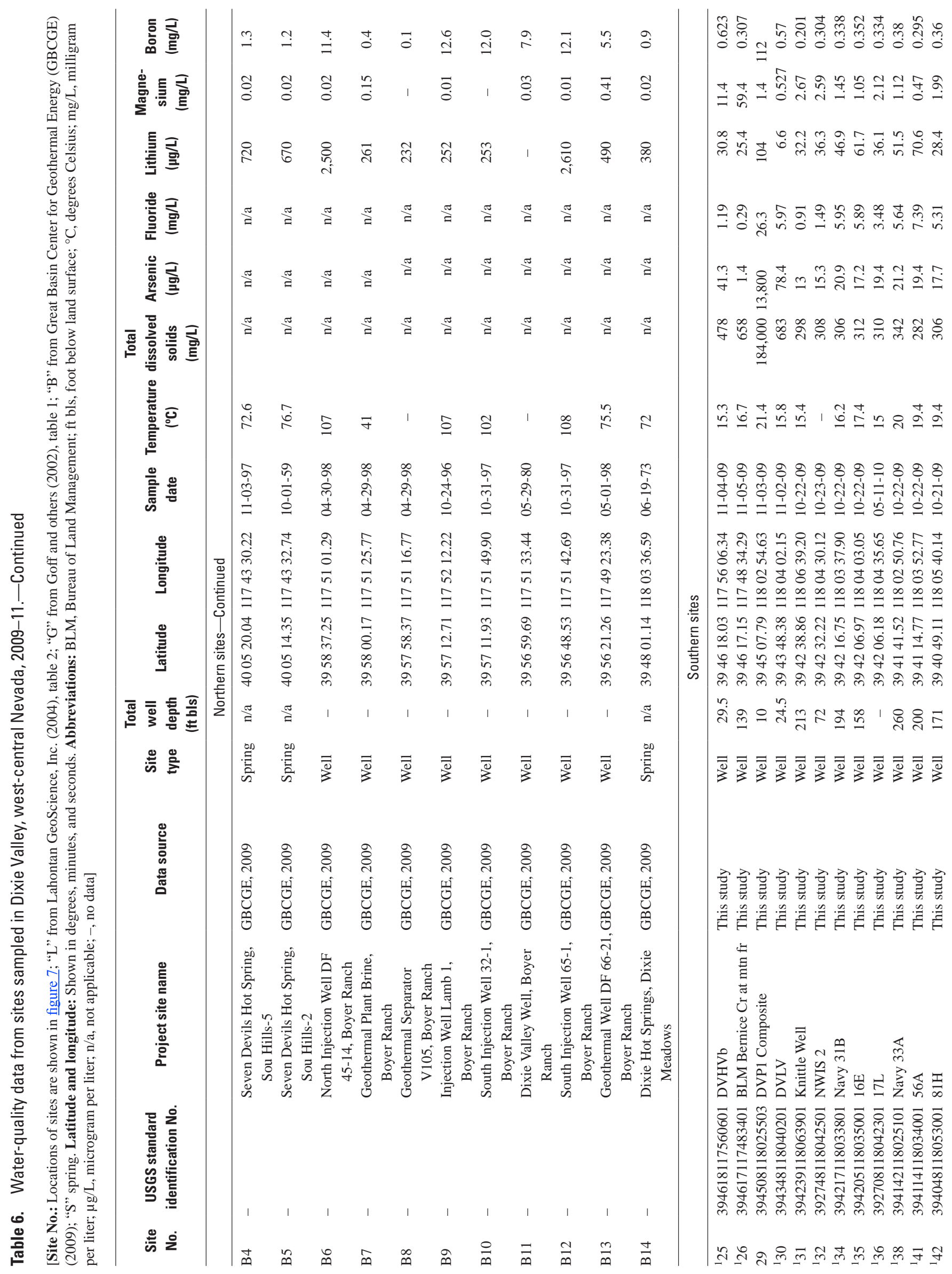




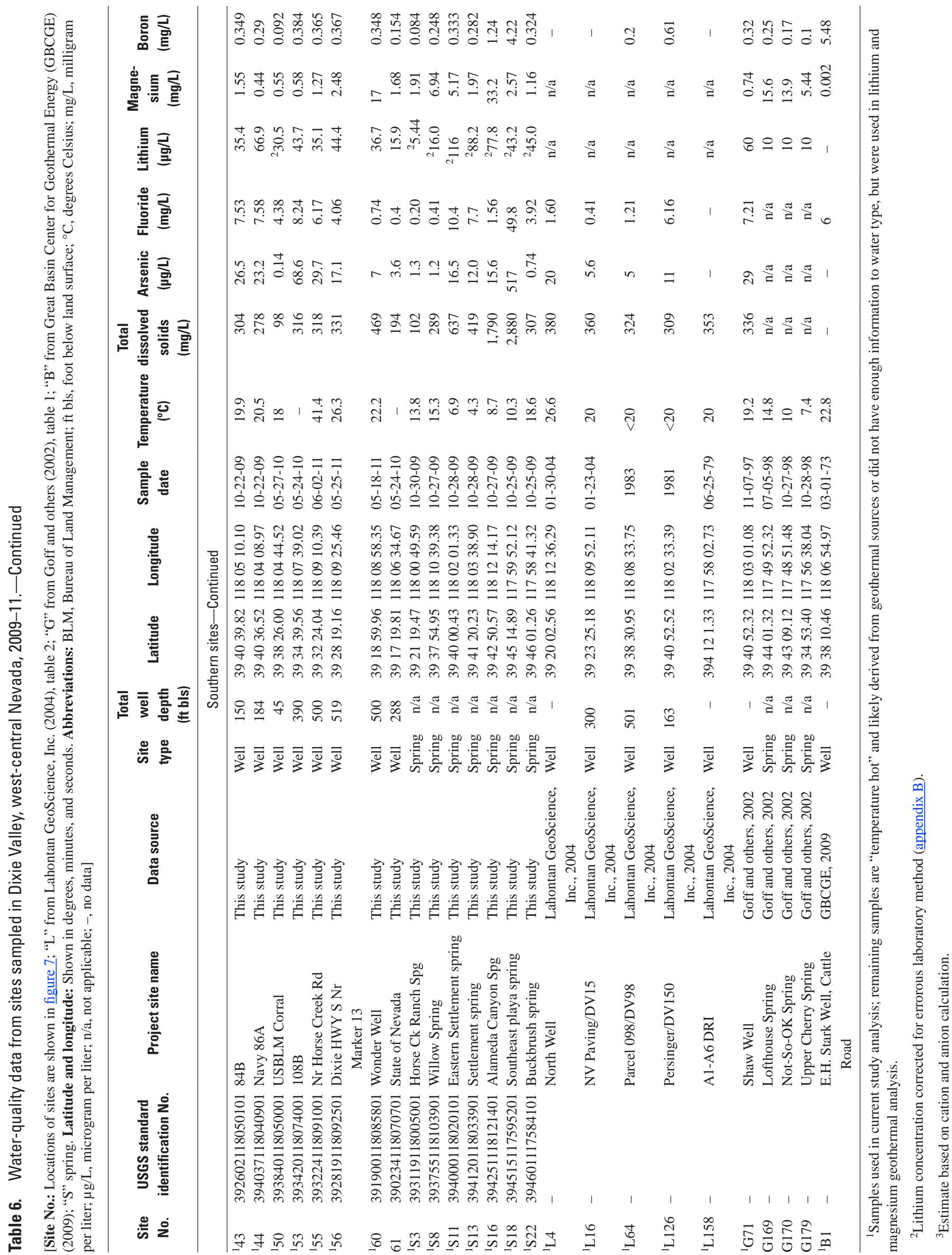




\section{Water-Level Change}

Groundwater levels in Dixie Valley have remained generally constant since the 1950s, but some localized change has occurred as a result of withdrawals for irrigation, livestock, domestic use, and augmentation of geothermal reservoir pressure. A comparison between the potentiometric surface map delineated in this study and the historical waterlevel elevation map from Cohen and Everett (1963) indicate that water levels have remained generally constant. In mostly undeveloped areas, water level differences between water-level maps were mostly attributed to a more spatially extensive dataset used in this study; however, in historically developed areas differences in water levels were reflective of the localized development. Generally undeveloped areas lacked sufficient data for evaluation. Mean decadal water levels for 19 wells are summarized in table 7 and represent areas of groundwater development. The earliest water-level measurement was made in mid-1951, and the most recent measurement was made in mid-2011. Each of the 19 wells had a minimum of 7 measurements spanning at least three decades; however, the average number of total measurements for any one well was 31 . Sufficient measurements were available to evaluate water-level change for eight wells across various time periods (fig. 6; table 7). Although water-level measurements representative of differing time periods are limited, some observations are provided here.

Water-level change measured in wells north of the playa is likely due to irrigation and geothermal pumping (wells 3-5, 7-10, and 15-20; fig. 4). Some water levels in the northernmost wells of Dixie Valley showed rising and declining patterns from the 1950s to 2011, corresponding to changes in agricultural pumping. For example, water levels in wells near the border of Dixie and Jersey Valleys (wells 3-5; fig. 4) declined from the late 1960s to early 1980s by about $15 \mathrm{ft}$, and then rose by as much as $5 \mathrm{ft}$ between measurements made in the 1980s and the 2000s (fig. 6A). The declining and subsequent rising patterns likely correspond to the cessation of agricultural pumping. Water levels in wells between the playa and the Churchill-Pershing County line (wells 15-20; fig. 4) declined by about 3-6 ft between the 1980s and early 2010s (wells 17, 18, table 7; fig. 6B). Largescale pumping to augment geothermal injection began in 1997 (Benoit and others, 2000). Several wells clustered near the Dixie Valley Geothermal Power plant are used to augment and monitor the injection of basin-fill water above the geothermal aquifer (wells not shown in fig. 6B). Wells farther east of the geothermal plant (wells 17 and 18) are used for irrigated agriculture.
Water levels measured in wells south of the playa, where the basin-fill aquifer is semi-confined (wells 45, 47, 50-52, fig. 4; table 7), have fluctuated by less than $4 \mathrm{ft}$ since the $1950 \mathrm{~s}$ and generally have risen by $0.7-3.0 \mathrm{ft}$ between the $1980 \mathrm{~s}$ and early 2010s (for example, see wells 47 and 50, fig. 6C). Many wells in this area were drilled to support an agricultural settlement that was present from the 1940s to mid-1980s. Between 1985 and 1987, the U.S. Navy purchased private land in this settlement area through a congressionally approved buyout of 12,000 acres (Misrach, 1990) to use as a supersonic testing ground. This action, in turn, resulted in the dismantling of most of the settlement homesteads, leaving many artesian wells uncapped and flowing for more than 20 years. Between 2002 and 2010, the U.S. Navy capped or sealed 65 wells, 45 of which were artesian (Gary Cottle, U.S. Navy, written commun., 2012). Fifteen of the 23 remaining wells in the area surveyed for this study are artesian (table 3, wells 30-52, noted by footnote; fig. 4), with water levels ranging from about $0.4 \mathrm{ft}$ bls to nearly $32 \mathrm{ft}$ above land surface (October 2009-August 2011). Artesian well depths range from 24.5 to $292 \mathrm{ft}$ bls (average about $180 \mathrm{ft}$ bls), whereas non-artesian wells range in depth from 45 to $200 \mathrm{ft}$ bls (wells 45, 47-52; average about $130 \mathrm{ft}$ bls). Rising water levels in nonartesian wells likely indicate aquifer recovery from reduced agricultural pumping and capping of flowing wells following the U.S. Navy land acquisition.

Water-level data from wells in southern Dixie Valley (south of latitude $39^{\circ} 35^{\prime} 0 " \mathrm{~N}$, fig. 4; table 3) are sparse. Well 88 has a lengthy water-level record and shows a decline in water-levels of about $3.5 \mathrm{ft}$ from the late 1980s to the late 2000s (fig. 6D). The water-level decline is possibly from groundwater withdrawals for livestock watering.

\section{Subsurface Flow}

Groundwater in basin-fill sediments moves northward from Fairview Valley and southward from Jersey Valley into Dixie Valley as subsurface inflow. Groundwater historically was thought to move southward from Pleasant Valley to Dixie Valley, as well as from Eastgate Valley to Cowkick Valley, from Cowkick Valley to Stingaree Valley, and, finally, as a combined flow entering Dixie Valley (Cohen and Everett, 1963, p. 17). Previous subsurface-inflow estimates from adjacent basins were based on residual differences between estimated recharge and discharge (Cohen and Everett, 1963; Harrill and Hines, 1995). In this study, subsurface inflow from adjacent basins through the basin-fill aquifer was estimated using Darcian flux calculations, which incorporate local aquifer transmissivity, current hydraulic gradients, and effective flow width near basin divides (table 8). 
Table 7. Wells with seven or more water-level measurements, Dixie Valley, west-central Nevada, 1950-2011.

[Site No.: Locations of sites are shown in figure 4. ft bls, foot below land surface; -, no data]

\begin{tabular}{|c|c|c|c|c|c|c|c|c|c|c|c|c|c|c|}
\hline \multirow{2}{*}{$\begin{array}{l}\text { Site } \\
\text { No. }\end{array}$} & \multicolumn{7}{|c|}{$\begin{array}{l}\text { Number of water levels } \\
\text { measured within decade }\end{array}$} & \multicolumn{7}{|c|}{$\begin{array}{l}\text { Average decadal water level } \\
\text { (ft bls) }\end{array}$} \\
\hline & 1950s & $1960 \mathrm{~s}$ & $1970 \mathrm{~s}$ & 1980s & 1990s & $2000 \mathrm{~s}$ & 2010-11 & 1950s & $1960 \mathrm{~s}$ & 1970s & 1980s & 1990s & $2000 s$ & 2010-11 \\
\hline${ }^{1} 03$ & - & - & - & 3 & - & 1 & 6 & - & - & - & 136.0 & - & 131.0 & 130.8 \\
\hline${ }^{1} 04$ & - & 2 & 5 & 7 & - & 1 & 7 & & 76.5 & 84.0 & 91.7 & - & 89.6 & 89.1 \\
\hline${ }^{1} 05$ & - & - & - & 5 & - & 1 & 6 & - & - & - & 96.2 & - & 96.0 & 95.1 \\
\hline 08 & - & - & 1 & - & - & 2 & 6 & - & - & 67.0 & - & - & 91.3 & 93.6 \\
\hline 09 & - & 1 & - & 6 & - & 1 & - & - & 92.0 & - & 101.2 & - & 102.1 & - \\
\hline 10 & - & - & - & 6 & - & 1 & - & - & - & - & 92.4 & - & 94.9 & - \\
\hline 15 & - & - & 1 & 3 & - & 2 & 1 & - & - & 40.0 & 31.2 & - & 49.8 & 56.8 \\
\hline 16 & - & - & 2 & - & - & 2 & 6 & - & - & 125.0 & & - & 133.9 & 134.2 \\
\hline${ }^{1} 17$ & - & - & - & 5 & - & 1 & 7 & - & - & - & 58.7 & - & 61.1 & 61.3 \\
\hline${ }^{1} 18$ & - & - & 1 & 4 & - & 1 & 1 & - & - & 57.0 & 54.1 & - & 61.4 & 59.9 \\
\hline 19 & - & - & - & 1 & - & 2 & 6 & - & - & - & 6.0 & - & 15.0 & 14.5 \\
\hline 20 & - & - & - & 1 & - & 2 & 6 & - & - & - & 6.0 & - & 14.3 & 14.1 \\
\hline 45 & 1 & - & - & 2 & - & 2 & 6 & 72.9 & - & - & 73.3 & - & 73.3 & 72.2 \\
\hline${ }^{1} 47$ & 15 & 13 & 9 & 6 & 6 & 1 & 6 & 28.3 & 29.7 & 31.5 & 33.2 & 32.1 & 30.6 & 30.1 \\
\hline${ }^{150}$ & 18 & 14 & 8 & 6 & 6 & 2 & 1 & 34.0 & 33.8 & 34.7 & 35.1 & 34.8 & 34.4 & 34.4 \\
\hline 51 & - & - & 1 & 2 & - & 1 & 8 & - & - & 38.0 & 37.3 & - & 34.7 & 34.9 \\
\hline 52 & - & - & - & 1 & - & 1 & 6 & - & - & - & 37.6 & - & 34.3 & 34.4 \\
\hline 53 & - & 1 & - & 3 & - & 1 & 6 & - & 126.0 & - & 131.4 & - & 128.8 & 128.9 \\
\hline${ }^{188}$ & - & - & - & 4 & 7 & 65 & - & - & - & 208.9 & 211.4 & 210.6 & 211.2 & - \\
\hline
\end{tabular}

${ }^{1}$ Site used in groundwater-level trend analysis (ig. 6).

Table 8. Annual subsurface inflow estimates from adjacent basins through basin-fill deposits to Dixie Valley, west-central Nevada.

[All values in acre-feet per year]

\begin{tabular}{lccr}
\hline \multicolumn{3}{c}{$\begin{array}{c}\text { Annual subsurface inflow estimates through } \\
\text { basin-fill sediments to Dixie Valley }\end{array}$} \\
\hline & $\begin{array}{c}\text { Cohen and } \\
\text { Everett (1963) }\end{array}$ & $\begin{array}{c}\text { Harrill and } \\
\text { Hines (1995) }\end{array}$ & This study \\
\hline Fairview Valley & 500 & 2,300 & $700-1,300$ \\
Eastgate, Cowkick, & 5,600 & 6,300 & $-^{1}$ \\
$\quad$ Stinagree Valleys & & & \\
Jersey Valley & 500 & 1,100 & $1,800-2,300$ \\
Pleasant Valley & 800 & 1,100 & $-^{2}$ \\
$\quad$ Total & 7,400 & 10,800 & $2,500-3,600$ \\
\hline
\end{tabular}

${ }^{1}$ Not estimated; water table below basin-fill sediments at basin boundary.

${ }^{2}$ Not estimated; no appreciable connection of basin-fill sediments between valleys.
Harrill and Hines (1995, p. 11) also hypothesized that groundwater might flow from Eastgate, Cowkick, and Stingaree Valleys to Dixie Valley, through fractured volcanic rocks beneath the Clan Alpine Mountains, and enter Dixie Valley somewhere in the northern part of the basin. This hypothesis was prompted by discrepancies between recharge and discharge estimates in northern and southern areas of Dixie Valley. There is no conclusive evidence to date (2014) supporting groundwater movement through more than 20 mi of fractured volcanic rocks beneath the mountain block. Subsurface inflow volumes reported in this study only represent flow through basin-fill deposits.

Subsurface inflow to Dixie Valley is the predominant form of groundwater discharge in Fairview Valley. Groundwater flows from Fairview Valley to Dixie Valley through a wide section of basin-fill deposits (about $13 \mathrm{mi}$ ) across a slight hydraulic gradient $\left(9.3 \times 10^{-4} \mathrm{ft} / \mathrm{ft}\right.$ between sites 59 and 58). Using basin-fill transmissivity estimated from both the aquifer test for well 60 (table 4) and the specific-capacity data from well 59 (Nevada driller's log 9665, specific capacity $=6 \mathrm{gpm} / \mathrm{ft}$, estimated transmissivity $=1,360 \mathrm{ft}^{2} / \mathrm{d}$ ) to estimate a range, the annual subsurface inflow from Fairview Valley to Dixie Valley ranges from 700 to 1,300 acre-ft/yr (table 8). This range falls between estimates by Cohen and Everett (1963) and Harrill and Hines (1995). 

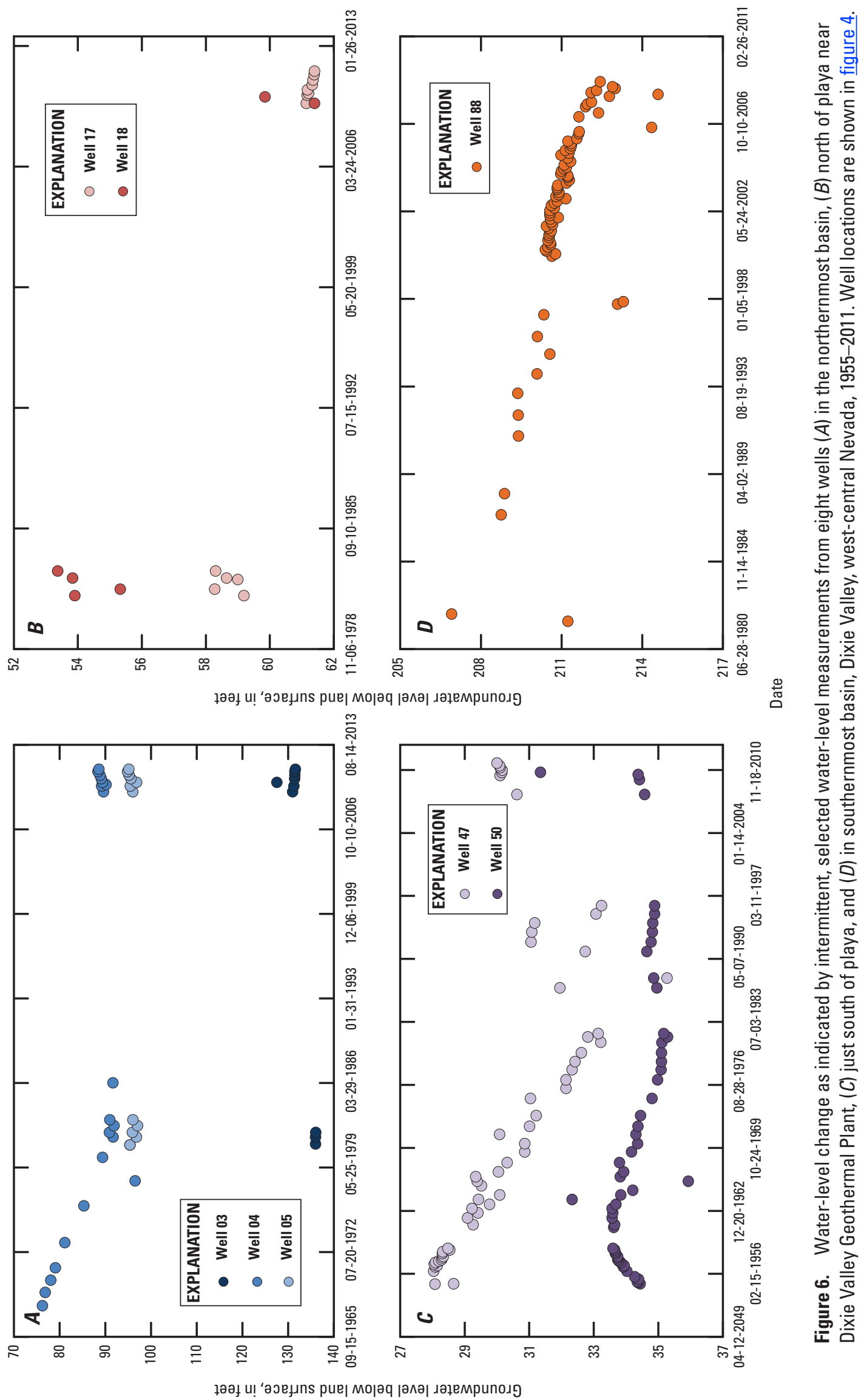
The basin-fill deposits between Stingaree Valley and Dixie Valley are constricted (less than $3.2 \mathrm{mi}$ ) with a steep hydraulic gradient $\left(1.4 \times 10^{-2} \mathrm{ft} / \mathrm{ft}\right.$ between sites 61 and 60$)$ as a result of consolidated rock outcrops within the basin boundary area (pl. 1). Groundwater possibly could enter Dixie Valley through four separate sections of basin fill between consolidated rock outcrops. However, based on available groundwater data and topographic gradients, the most likely location for groundwater to enter Dixie Valley is through the basin-fill section containing Dixie Valley Wash (pl. 1). The three remaining basin-fill sections to the northeast and southwest are topographically higher, likely have higher bedrock elevations and thinner basin fill, and, therefore, are less likely to have groundwater flow across the boundary. Andesite tailings adjacent to a dry, abandoned mine shaft immediately northeast of Dixie Valley Wash (site 90) indicate bedrock is present near the mine base at about $136 \mathrm{ft}$ bls. The presence of bedrock above the water table indicates that subsurface flow between the two boundaries is not occurring through overlying basin-fill deposits (pl. 1). Therefore, a Darcian flux calculation was not made at this basin boundary because the transmissivity of the volcanic rocks is unknown. However, a hydraulic gradient is present across the basin boundary, suggesting that some volume of groundwater might be moving from basin fill in Stingaree Valley, through the shallow volcanic rock dividing Stingaree Valley and Dixie Valley, and then reentering the basin fill in Dixie Valley.

Subsurface inflow to Dixie Valley from Jersey Valley occurs through a 2.5-3.1 mi section of basin-fill deposits with a $5.7 \times 10^{-3} \mathrm{ft} / \mathrm{ft}$ hydraulic gradient (between sites 3 and 4), but limited aquifer transmissivity data are available in the area. The closest transmissivity estimate, 2,900 ft $2 / \mathrm{d}$ (NDWR well $\log 13405$ [table 4]), is based on specific-capacity data from a well site more than $4 \mathrm{mi}$ to the southwest of the basin divide. Potential subsurface inflow estimated from the variable basin width ranges from 1,800 to 2,300 acre-ft/yr, and is at least 700 acre-ft/yr greater than previous estimates (table 8).

Groundwater flow from Pleasant Valley to Dixie Valley was not estimated in this study because there is no appreciable connection of basin-fill sediments between the two valleys. Near the Pleasant Valley southern hydraulic terminus, there is only a 1,750-ft-wide section of limestone and dolomite (Natchez Pass Formation; Johnson, 1977, p. 16). A hydraulic gradient is present between the basin fill in each respective valley (pl. 1), indicating that groundwater could flow through carbonate rocks at the divide, but a Darcian flux calculation was not made as transmissivity of the carbonate rocks is not known. Previous estimates of subsurface inflow from Pleasant Valley range from 800 to 1,100 acre-ft/yr (table 8) (Cohen and Everett, 1963; Harrill and Hines, 1995). However, precipitation data used by Harrill and Hines (1995) to estimate recharge in Pleasant Valley, and subsequently subsurface flow to Dixie Valley, might have been skewed (Jim Harrill, USGS retired, oral commun., 2010), resulting in an underestimate of groundwater moving between the two basins.

\section{Chemical Composition of the Basin-Fill Aquifer}

Water-quality data were used to evaluate the chemical signature and quality of groundwater in the Dixie Valley basin-fill aquifer. Major ion and stable isotope data were used to describe the chemical signature, to identify possible differences in general chemistries between basin-fill and playa groundwater, and to interpret relative amounts of meteoric water possibly recharging the basin-fill aquifer. Changes in seasonal groundwater chemistry were also evaluated using selected trace metals and nitrogen. The chemical quality of groundwater was evaluated relative to established waterquality standards.

The groundwater signature and quality of the Dixie Valley basin-fill aquifer were characterized using groundwater-quality data from 52 wells and 15 valley springs (fig. 7; table 6). Groundwater quality data were collected from 32 wells and 13 valley springs between October 2009 and June 2011. Water-quality sampling followed U.S. Geological Survey (2006) field procedures to ensure comparability between samples. Non-artesian wells were purged by removing three well volumes of water prior to sampling. This ensured the sampling of aquifer water rather than borehole water. Groundwater flowing from artesian wells (table 3) was assumed to be representative of the aquifer; therefore, purging was deemed unnecessary. Samples were analyzed by two USGS laboratories: National Water Quality Laboratory, Lakewood, Colorado, and Reston Stable Isotope Laboratory, Reston, Virginia. Most wells were sampled in autumn 2009; an 11-well subset of these wells was sampled again in spring 2010 to investigate seasonal water-quality changes. Three of the 32 wells were drilled in southern Dixie Valley during winter 2010-11 and were sampled during aquifer testing in May-June 2011. Twenty-two additional samples reported in previous investigations were incorporated in the analysis to expand the spatial characterization of water quality in the basin-fill aquifer. These additional samples included nine well samples collected by Lahontan GeoScience, Inc. (2004), eight well and two spring samples collected by Goff and others (2002), and three well samples from Great Basin Center for Geothermal Energy (2004).

Limitations related to using multiple data sources included the amount and quality of supplemental data describing well construction and sampling and analysis techniques. Well construction information related to historical samples, including depth drilled and interval screened, rarely was provided (table 6; Goff and others, 2002; Great Basin Center for Geothermal Energy, 2004; Lahontan GeoScience, Inc., 2004). A lack of construction information precluded evaluation of chemical gradients and composition differences between neighboring wells, as these differences could be related to groundwater sampling depth. Another limitation was that the same parameters measured in historical samples were not always measured in this study, preventing direct comparison of portions of the datasets. 


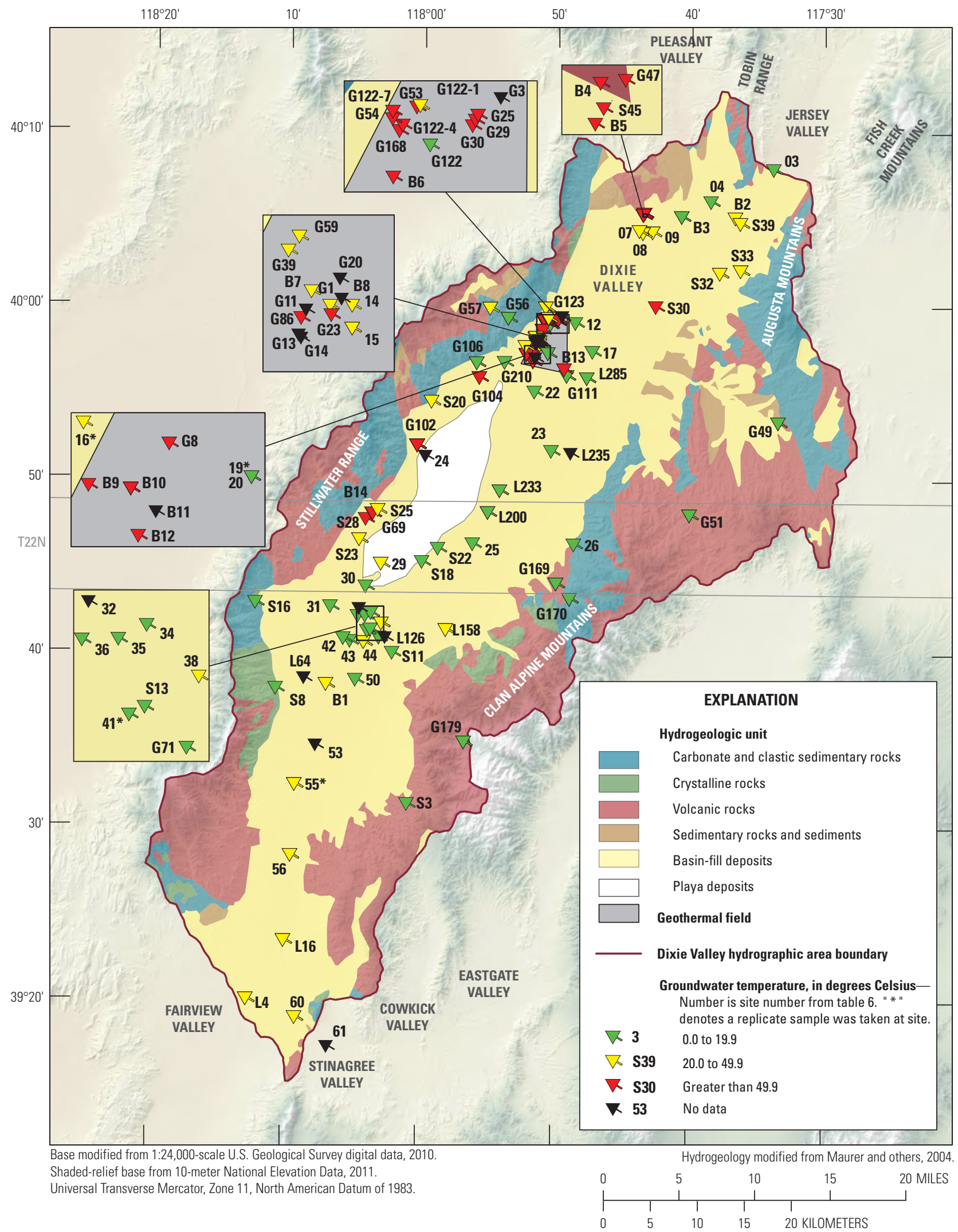

Figure 7. Locations of sites sampled for water quality and measured field groundwater temperature, Dixie Valley, west-central Nevada, 1959-2011. 


\section{Quality Assurance}

Laboratory equipment and field blanks were run for quality assurance on pumps and sampling lines prior to and during sampling to ensure that sampling equipment did not contaminate samples. Internal components of the pump used in this study to purge and sample water from wells are made of stainless steel, which can corrode and release trace metals (Wilde, 2004), even after diligent decontamination. Although no corrosion was observed on the pump, several trace metals generally at or near laboratory reporting-limit concentrations were measured in laboratory equipment blanks, including aluminum $(5.8 \mu \mathrm{g} / \mathrm{L})$, manganese $(0.43-1.96 \mu \mathrm{g} / \mathrm{L})$, barium $(0.15 \mu \mathrm{g} / \mathrm{L})$, arsenic (0.06-0.19 $\mu \mathrm{g} / \mathrm{L})$, and antimony $(0.26 \mu \mathrm{g} / \mathrm{L})$. Field equipment blanks were used to evaluate possible contamination resulting from processing groundwater samples in the field. Although concentrations of several trace metals (iron, cobalt, manganese, magnesium, lithium, strontium, and arsenic) measured in field blanks were greater than laboratory reporting limits (within 1 percent), these concentrations were within an average of 2 percent of those in environmental samples.

Sequential replicate samples were collected to quantify variability associated with the collection and processing of a sample (U.S. Geological Survey, 2006). Replicate samples were collected from wells 16, 19, 41, and 55 (fig. 7); replicate and environmental sample concentrations generally were similar (coefficient of variation average of less than 10 percent).

\section{Chemical Signature}

The chemical signature of groundwater in Dixie Valley varies spatially. As water moves through an aquifer, minerals from encountered rocks and sediments dissolve and precipitate leaving a record in the groundwater chemistry. This record is represented mainly in the major-ion composition of groundwater, which can be used to evaluate groundwater source areas and flow characteristics. Major ion chemistry in groundwater representing the upper $500 \mathrm{ft}$ of the basin-fill aquifer was used to further evaluate the playa as a flow barrier separating northern and southern groundwater with a water typing and statistical comparison using the Mann-Whitney rank sum test (Bradley, 1968).

Differences in water chemistry between the northern and southern areas of Dixie Valley support the hypothesis that the playa acts as a groundwater divide. General groundwater ionic composition is shown in figure 8, where data points represent a relative proportion of major ions. Groundwater in northern Dixie Valley generally can be characterized as a sodium bicarbonate-chloride type $\left(\mathrm{Na}-\mathrm{HCO}_{3}-\mathrm{Cl}\right.$; fig. 8). Most samples contain 40-80 percent sodium (little potassium [K] present relative to sodium) and 15-50 percent calcium. Magnesium (Mg) ranges from 10 to 30 percent for most northern groundwater. Bicarbonate and chloride generally co-dominate the anion composition of northern groundwater, with most samples composed of 20-50 percent and 25-60 percent bicarbonate and chloride, respectively. Sulfate $\left(\mathrm{SO}_{4}\right)$ also was present in these samples, contributing from 20 to 40 percent of the anion composition (fig. 8). Groundwater south of Township 22N can be characterized as a sodium bicarbonate-sulfate type $\left(\mathrm{Na}-\mathrm{HCO}_{3}-\mathrm{SO}_{4}\right)$ (fig. 8). Most southern samples were dominated strongly by sodium (Na; 70-100 percent), with varying calcium contributions (Ca; 0-45 percent). Anion compositions in southern groundwater contain mixtures of bicarbonate $\left(\mathrm{HCO}_{3} ; 40-65\right.$ percent) and $\mathrm{SO}_{4}$ (25-50 percent) (fig. 8). Chloride was also present in these samples, contributing to about $15-40$ percent of the anion composition.

A distinguishing characteristic between southern and northern groundwater is the lower contribution of magnesium in southern groundwater relative to that in the north. Southern groundwater is nearly 100 percent depleted of magnesium, whereas magnesium contributions in northern groundwater generally range from 10 to 30 percent. High concentrations of magnesium in groundwater indicate the presence of either magnesium carbonates (dolomite, hydromagnesite, or magnesite) or mafic (basalt) rock within the groundwater flow path (Hounslow, 1995). Large volumes of basalt are present on the east and west side of the basin, but basalt is more prevalent as outcrops on the east side of the basin in the Clan Alpine Mountains. Corresponding with more prevalent basalt outcrops in the eastern Clan Alpine Mountains, groundwater sampled east of the playa was enriched in magnesium relative to the rest of the basin. Water in southern wells 26 and 60 has much greater concentrations of magnesium than most southern wells on the valley floor (table 6). High magnesium concentrations in the upgradient groundwater-flow path in southern Dixie Valley indicate that groundwater is losing magnesium as it approaches the playa. Loss of magnesium could be the result of the incorporation of magnesium into clay-rich sediments (see section, “Mixing of Geothermal and Basin-Fill Groundwater").

In addition to water typing, statistical comparisons of major ions indicate that northern and southern waters differ significantly. Mann-Whitney rank sum tests (Bradley, 1968) indicate all major ions, including dissolved solids, differed significantly between samples collected north and south of Township 22N (all p-values $<0.007,99$-percent confidence level). These results indicate that mixing between groundwater north and south of the playa is minimal.

Several sites in northern Dixie Valley plot as outliers in figure 8. Northern sites 23 and G123 contained about 40 percent magnesium (10-30 percent higher than other northern samples). The higher magnesium in well 23 could result from groundwater flowing from the magnesium-rich dolomite and basalt present in the Clan Alpine Mountains, whereas magnesium in well G123 could be from the magnesium-rich basalt present in the gabbroic complexes in the Stillwater Range (fig. 7; rock types are listed in table 2). 


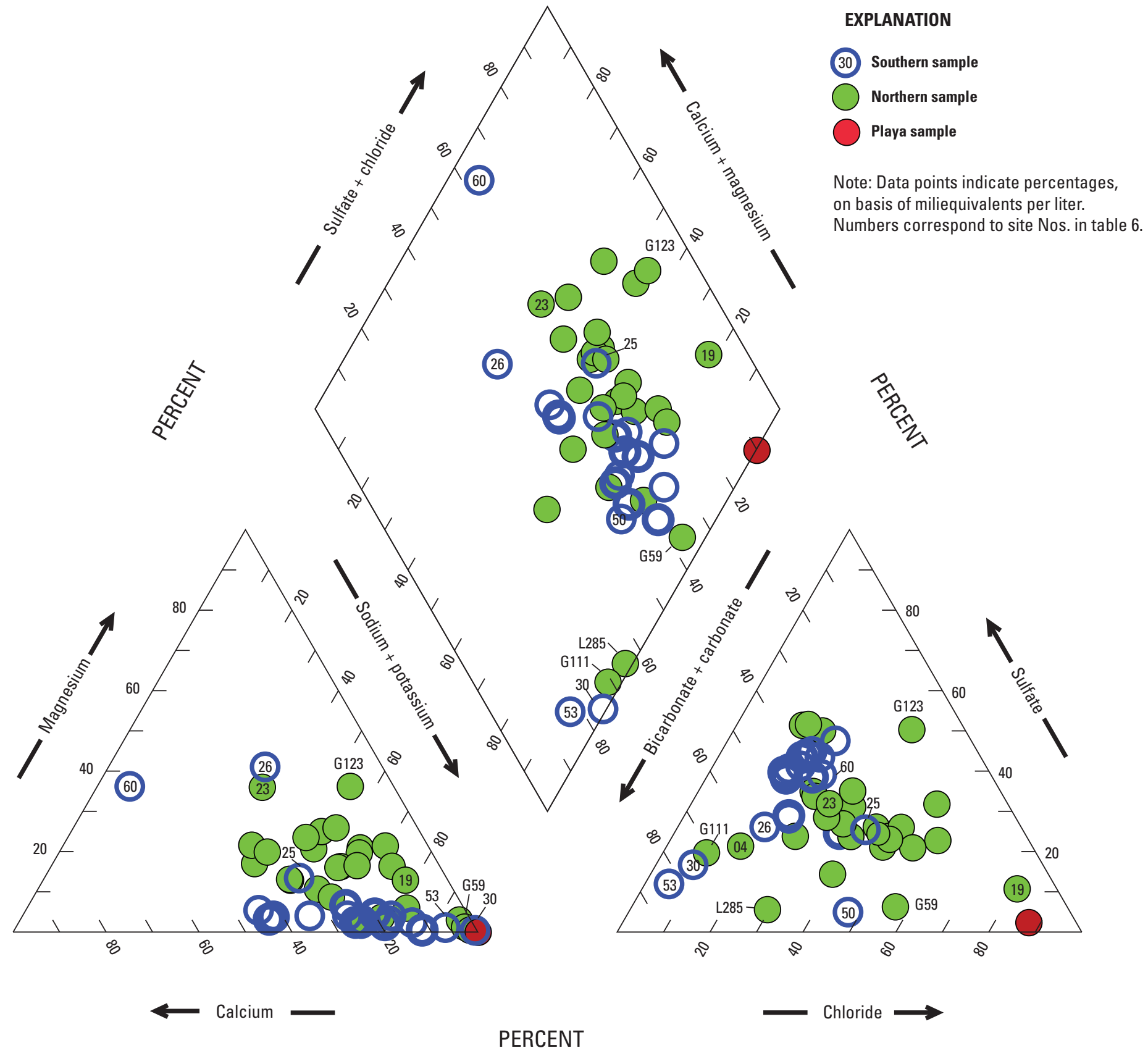

Figure 8. Trilinear diagram showing general water-quality conditions in northern and southern areas of Dixie Valley, west-central Nevada. Relative concentrations of cations and anions are presented in lower left and right triangles, respectively; relative concentrations are projected onto the central diamond to show combined major-ion chemistry. 
Several characteristically different groundwater anion compositions were detected in samples or groups of samples in northern Dixie Valley (A = wells L285 and G59; B = well 19). The samples collected from wells L285 and G59 had the lowest sulfate contribution. Groundwater samples collected from well 19 contained the highest chloride and lowest bicarbonate-sulfate concentrations of any other sample. Differences between these three samples and those of neighboring wells all near or in the geothermal field could be related to the depth of groundwater sampled (depths of wells L285 and 19 were 55 and $50 \mathrm{ft}$ bls, respectively), but a lack of construction information for many wells results in inconclusive comparisons.

Several outlying samples also were present in the southern sites (fig. 8). Samples from wells 26 and 60, which are on the alluvial fan of the Clan Alpine Mountains and the Stingaree Valley boundary, respectively, contained substantially less sodium (contributions less than 35 percent) than other wells, and groundwater in well 60 had much more calcium (contribution of about 60 percent). These differences likely result from the upgradient position of these wells in the groundwater flow path near the Dixie Valley basin boundaries (fig. 7). Samples collected from wells 30 and 53 had the greatest bicarbonate contributions when compared with all samples (northern and southern sites). The sample from well 50 had higher chloride contributions and came from a shallower well depth (less than $50 \mathrm{ft}$ ) than most southern wells.

\section{Stable Isotopes}

Precipitation is altered by local meteoric processes (that is, evaporative enrichment) before infiltrating to become groundwater (Clark and Fritz, 1997). Therefore, the stable isotopic signature of oxygen-18 and deuterium in precipitation can aid in groundwater characterization. Samples were collected (90 total samples from 13 sites) for isotopic evaluation of mountain-block and valley-floor precipitation between May 2009 and May 2011 (appendix A). Mountainblock precipitation samples (42 samples from 9 sites, collected each spring and autumn) were collected by Mahannah and Associates, LLC, and Interflow Hydrology, Inc. Subterranean samplers, similar to those used by Kormos (2005) and Huntington and Niswonger (2012), were used for the collection of samples representative of groundwater recharge. Samples of valley floor precipitation (48 samples from 4 sites, collected quarterly) were collected by USGS personal from bulk precipitation collectors. Mineral oil was added to precipitation collectors to prevent evaporation of accumulated water.

Stable isotopes of oxygen-18 and deuterium were evaluated using water samples collected from 32 wells and 12 valley-floor springs (table 3, denoted by footnote as site sampled for current study) and precipitation from 4 valley-floor and 9 mountain-block locations (Interflow Hydrology, Inc., written commun., 2012) (appendix A; fig. 9). Precipitation signatures of oxygen-18 and deuterium were used to compute the local meteoric water line (LMWL). Values ranged from -16.8 to 5.0 and -128.0 to 15.0 per mil, respectively, at valleyfloor locations, and from -16.8 to -7.9 and -126.0 to -61.6 per mil, respectively, at mountain-block locations. The variation in measurements from more negative to more positive values reflects evaporation of precipitation during warmer months. Average annual signatures of oxygen-18 and deuterium were -11.2 and -89.1 per mil at valley floor locations (2010-late 2011) and -14.1 and -106.0 per mil at mountain block locations (2009-early 2011).

Most mountain-block precipitation falls between October and April of each year (cool season). During water year 2010, about 76 percent of total annual mountain-block precipitation (Mahannah and Associates, LLC, and Interflow Hydrology, Inc., written commun., 2012) occurred between October and April; during water year 2011, cool-season precipitation increased to 83 percent of the annual total. Cool-season oxygen-18 and deuterium signatures of mountain-block precipitation averaged -15.5 and -117.9 per mil, respectively, in water years 2010-11 (fig. 9). Warm-season oxygen-18 and deuterium signatures of mountain-block precipitation averaged -14.1 and -104.3 per mil, respectively, in water year 2010 only (no water year 2011 warm-season data available). To account for these differences in contributions from warm- and cool-season precipitation, isotopic signatures were weighted by the relative contribution of seasonal precipitation volumes, and the results were summed, thereby calculating an annual volume-weighted isotopic signature at each site, similar to Izbicki (2004).

Average volume-weighted, mountain-block precipitation signatures of oxygen-18 and deuterium (over water year 2010) were -15.3 and -116.0 per mil, respectively (fig. 9).

Isotopic signatures of both cold and warm basin-fill groundwater (sampled from 43 sites) provide insight on recharge sources and groundwater mixing. The mean oxygen-18 and deuterium signature for all basin-fill groundwater sites was -15.9 and -125.7 per mil, respectively. This signature was about 0.4 and 7.8 per mil more negative (lighter) in oxygen-18 and deuterium, respectively, than the mean winter mountain-block precipitation signatures. This indicates that most groundwater sampled in this study likely was recharged under cooler climate conditions (Rademacher and others, 2002). Mean geothermal (temperatures greater than $50{ }^{\circ} \mathrm{C}$ ) groundwater signatures of oxygen-18 and deuterium were -11.4 and -126.2 per mil. Geothermal samples exhibited similar deuterium signatures as basin-fill groundwater, but were about 4.5 per mil more enriched in oxygen-18 than basin-fill groundwater and about 5.4 per mil more enriched than the LMWL for a similar deuterium value. Most basin-fill (cool and warm) groundwater samples analyzed lie parallel to the LMWL, but are slightly (about 0.5-1.5 per mil, or an average of 1 per mil) more enriched in oxygen-18 relative to deuterium when compared to the LMWL. This apparent shift in oxygen-18 signatures of basin-fill groundwater from the LMWL likely is evidence of mixing between basin-fill and geothermal groundwater (fig. 9). 


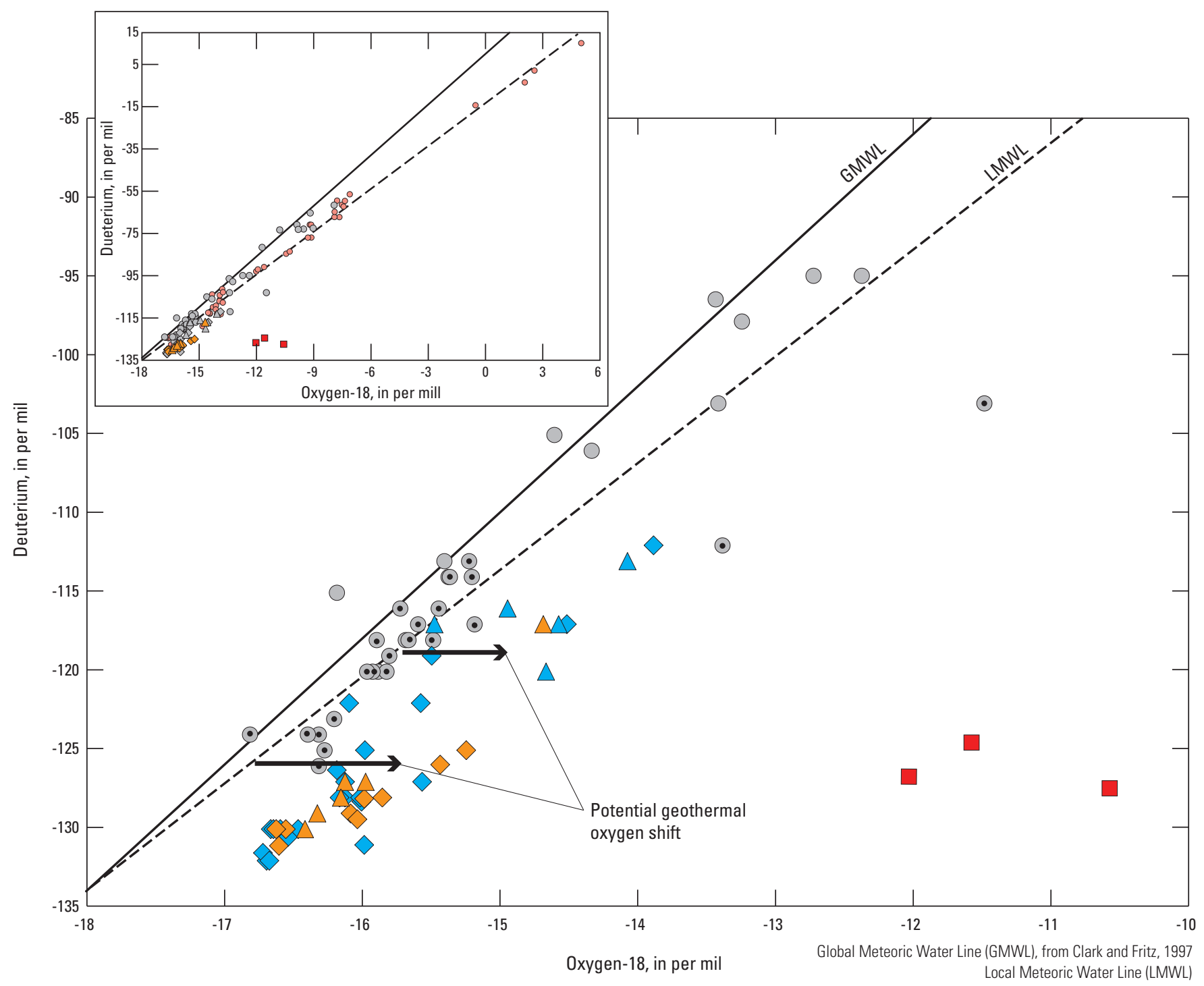

EXPLANATION

\begin{tabular}{llll} 
Precipitation & \multicolumn{2}{c}{ Groundwater } & Temperature, in degrees \\
Valley floor & $\diamond$ & Wells & 0 to 19.9 \\
Mountain block & $\triangle$ & Springs & 20.0 to 49.9 \\
- Cool-season mountain block & $\square$ & Geothermal wells & $\begin{array}{r}\text { Greater than or } \\
\text { equal to } 50\end{array}$
\end{tabular}

Figure 9. Isotopic signature of groundwater, springs, and precipitation at selected sites in Dixie Valley, west-central Nevada, 2009-11. Small graph shows full dataset, large graph highlights groundwater and spring datasets in relation to cool season precipitation. 


\section{Chemical Quality of Groundwater}

Dixie Valley groundwater quality was evaluated with respect to national primary and secondary drinking-water standards (table 9; U.S. Environmental Protection Agency, 2009). Primary standards (maximum contaminant levels [MCLs]) have been established by the U.S. Environmental Protection Agency for constituents that pose potential health risks to humans. Secondary standards generally are nonenforceable guidelines designed to ensure water quality with desirable cosmetic or aesthetic characteristics such as taste and odor (U.S. Environmental Protection Agency, 2009, p. 6); however, the Nevada Division of Environmental Protection enforces secondary standards (Nevada Administrative Code 445A.455).

Arsenic concentrations in samples from 41 of 64 sites exceeded the primary drinking water standard $(10 \mu \mathrm{g} / \mathrm{L}$; U.S. Environmental Protection Agency, 2009) (table 9). Arsenic is present in groundwater throughout Dixie Valley as a result of groundwater interaction with the volcanic rocks in surrounding mountain blocks and volcanic-rock-derived basin-fill sediments. Arsenic concentrations in volcanic rocks are highly variable, but high concentrations are common in basalt, rhyolite, and gabbro (Boyle and Jonasson, 1973, p. 256). High arsenic concentrations generally were measured near the playa fringe or near the geothermal plant from shallow wells (less than $100 \mathrm{ft}$ deep, where depth data are available), whereas lower concentrations were measured in or near mountain fronts. The highest arsenic concentration measured in the basin-fill aquifer was near the geothermal field $(1,650 \mu \mathrm{g} / \mathrm{L}$, site $\mathrm{G} 1$, table 6$)$.

Fluoride concentration exceeded the MCL of $4 \mathrm{mg} / \mathrm{L}$ (U.S. Environmental Protection Agency, 2009) at 17 of 45 sites and exceeded the Nevada secondary standard of $2 \mathrm{mg} / \mathrm{L}$ (Nevada Administrative Code 445A.455) at 21 of 45 sites (table 9). Most fluoride exceedances occurred at southern sites (fig. 10). The source of fluoride is likely natural and derived from groundwater interaction with volcanic and igneous rocks. Fluoride occurs in biotite, which is present in granite and rhyolite (Edmunds and Smedley, 2013), both of which constitute most of the mountain block in the southern parts of the Stillwater Range and Clan Alpine Mountains (Willden and Speed, 1974) (ig. 10). Fluorspar, a fluoride-containing mineral, historically was mined in the southeastern Stillwater Range in southern Dixie Valley, as well as at the Wonder mine in the southwestern Clan Alpine Mountains (Wilden and Speed, 1974, p. 50).

The national secondary drinking water standard (SMCL) for TDS (500 mg/L; U.S. Environmental Protection Agency, 2009) was exceeded in samples collected from 35 of 65 sites (mostly in northern Dixie Valley) (table 9; fig. 11). The State of Nevada enforces a secondary drinking water standard of 1,000 mg/L (exceeded in 15 of 65 sites, fig. 11). A large volume of carbonate rock is present in the northern areas of the Stillwater Range and the Clan Alpine Mountains, which may contribute to high TDS concentrations (fig. 11). The highest TDS concentrations, ranging from 563 to 3,580 mg/L, were from samples in wells screened in shallow intervals (average bottom screened interval of $130 \mathrm{ft}$ bls), whereas samples with TDS concentrations below the secondary standard were from wells screened in deep intervals (average bottom screened interval of $253 \mathrm{ft}$ bls). High concentrations of TDS also could be derived from wind-transported salts deposited in mountain-block recharge areas or from downward percolation of evaporated lake water during the Pleistocene or early Holocene. Wind-blown salts originate from the Dixie Valley playa or the Carson Desert playa just west of the Stillwater Range (fig. 1). Both playas are remnants of Pleistocene lakes where high concentrations of evaporites accumulated during more than 10,000 years of drying. Predominant wind patterns from the west and southwest (Garcia and others, 2014) likely guide the depositional pattern, leading to greater concentrations in the north.

The SMCL for manganese $(0.05 \mathrm{mg} / \mathrm{L})$ was exceeded in samples collected from 15 of 62 sites (table 9), with exceedance locations distributed across the valley. Noticeable effects of manganese concentrations in groundwater greater than the SCML include a bitter metallic taste and dark color that can stain (U.S. Environmental Protection Agency, 1992). High manganese concentrations can be associated with high iron concentrations; high iron concentrations typically occur under reducing conditions characterized by low dissolved oxygen and nitrate (McMahon and Chapelle, 2008). Of the 62 wells sampled for manganese, 20 also had dissolved oxygen, iron, and nitrate data. Groundwater samples that had manganese and iron concentrations greater than their respective secondary drinking water standards had dissolved oxygen concentrations ranging from 0.1 to $3.1 \mathrm{mg} / \mathrm{L}$ and nitrate + nitrite (as $\mathrm{N}$ ) concentrations ranging from 0.016 to $0.034 \mathrm{mg} / \mathrm{L}$.

Boron does not have a national drinking water standard, but can cause adverse health effects to humans (U.S. Environmental Protection Agency, 2008) and can be highly toxic to plants (Eaton, 1935). The World Health Organization suggests a provisional guideline of $0.5 \mathrm{mg} / \mathrm{L}$ (World Health Organization, 2003) for states without a boron standard. The World Health Organization guideline was exceeded in 33 of 60 sites (table 9), most of which are adjacent to the playa or in northern Dixie Valley. Boron sources in groundwater can be from weathering of sedimentary rocks such as shale and borate minerals formed in association with evaporites (Williams and Hervig, 2002). In the 1870s, northern playa salt deposits were mined for borax and ulexite, both boron-containing minerals (Vanderburg, 1940, p. 43). Although no chemical analysis for boron was done on playa salts as part of this study, boron concentrations in shallow playa groundwater (well 29) ranged from 85.4 to $112 \mathrm{mg} / \mathrm{L}$. 
Table 9. Summary of drinking-water standards and exceedances for groundwater sites in the basin-fill aquifer, Dixie Valley, westcentral Nevada.

[Exceedances are summarized based on location north or south of Township 22N (fig. 7) . Percentage above the drinking-water standard for playa well 29 also is shown for comparison. Constituent: National drinking water standards are available for mercury (0.002 mg/L), nitrate (10 mg/L as N), and nitrite (1 mg/L as $\mathrm{N}$ ). Mercury was not sampled, only total nitrogen (nitrate + nitrite, as $\mathrm{N}$ ) was sampled, and relative quantities of nitrate and nitrite cannot be determined. National drinking-water standards: All values are in milligrams per liter (mg/L) except for $\mathrm{pH}$, which is in standard units; primary standards from U.S. Environmental Protection Agency (2009); secondary standards from U.S. Environmental Protection Agency (1992). -, no standard; n/a, not applicable]

\begin{tabular}{|c|c|c|c|c|c|c|c|}
\hline \multirow{2}{*}{ Constituent } & \multicolumn{2}{|c|}{$\begin{array}{l}\text { National drinking-water } \\
\text { standards }\end{array}$} & \multirow{2}{*}{$\begin{array}{l}\text { Number } \\
\text { of sites } \\
\text { sampled }\end{array}$} & \multicolumn{3}{|c|}{ Number of sites exceeding standard } & \multirow{2}{*}{$\begin{array}{l}\text { Concentration } \\
\text { at well 29, playa } \\
\text { (percent of } \\
\text { standard) }\end{array}$} \\
\hline & Primary & Secondary & & Total & Northern sites & Southern sites & \\
\hline Aluminum & - & $0.05-0.2$ & 42 & 2 & 1 & 1 & 900 \\
\hline Antimony & 0.006 & - & 31 & 16 & 6 & 10 & 383 \\
\hline Arsenic & 0.01 & - & 64 & 41 & 19 & 22 & 120,500 \\
\hline Cadmium & 0.005 & - & 30 & 0 & $\mathrm{n} / \mathrm{a}$ & $\mathrm{n} / \mathrm{a}$ & $\mathrm{n} / \mathrm{a}$ \\
\hline Chloride & - & 250 & 67 & 11 & 10 & 1 & 43,800 \\
\hline Chromium & 0.1 & - & 30 & 0 & $\mathrm{n} / \mathrm{a}$ & $\mathrm{n} / \mathrm{a}$ & $\mathrm{n} / \mathrm{a}$ \\
\hline Copper & 1.3 & 1 & 55 & 0 & $\mathrm{n} / \mathrm{a}$ & $\mathrm{n} / \mathrm{a}$ & $\mathrm{n} / \mathrm{a}$ \\
\hline Fluoride & 4 & ${ }^{1} 2$ & 45 & 17 & 3 & 14 & 576 \\
\hline Selenium & 0.05 & - & 31 & 0 & $\mathrm{n} / \mathrm{a}$ & $\mathrm{n} / \mathrm{a}$ & $\mathrm{n} / \mathrm{a}$ \\
\hline Silver & & 0.1 & 30 & 0 & $\mathrm{n} / \mathrm{a}$ & $\mathrm{n} / \mathrm{a}$ & $\mathrm{n} / \mathrm{a}$ \\
\hline Sulfate & - & 250 & 67 & 7 & 6 & 1 & 1,674 \\
\hline Thallium & 0.002 & - & 30 & 0 & $\mathrm{n} / \mathrm{a}$ & $\mathrm{n} / \mathrm{a}$ & 100 \\
\hline Total dissolved solids & & $500\left({ }^{3} 1,000\right)$ & 65 & 35 & 30 & 5 & 35,700 \\
\hline Uranium & 0.03 & & 32 & 0 & $\mathrm{n} / \mathrm{a}$ & $\mathrm{n} / \mathrm{a}$ & 1,455 \\
\hline Zinc & & 5 & 49 & 0 & $\mathrm{n} / \mathrm{a}$ & $\mathrm{n} / \mathrm{a}$ & $\mathrm{n} / \mathrm{a}$ \\
\hline Boron $^{4}$ & & ${ }^{5} 0.5$ & 60 & 33 & 28 & 5 & 19,740 \\
\hline
\end{tabular}

${ }^{1}$ Nevada specific secondary drinking water standard. Number of sites exceeding the Nevada secondary standard of 2.0 mg/L equals 21 (U.S. Environmental Protection Agency, 1992). Number of northern and southern sites exceeding standard equals 6 and 15, respectively.

${ }^{2}$ Acceptable range for $\mathrm{pH}$.

${ }^{3}$ The State of Nevada enforces a secondary drinking water standard of 1,000 mg/L.

${ }^{4}$ Not regulated by U.S. Environmental Protection Agency, but has known health effects.

${ }^{5}$ Provisional guideline value (World Health Organization, 2003); no maximum contaminant level for boron, but can cause adverse health effects (U.S. Environmental Protection Agency, 2008). 


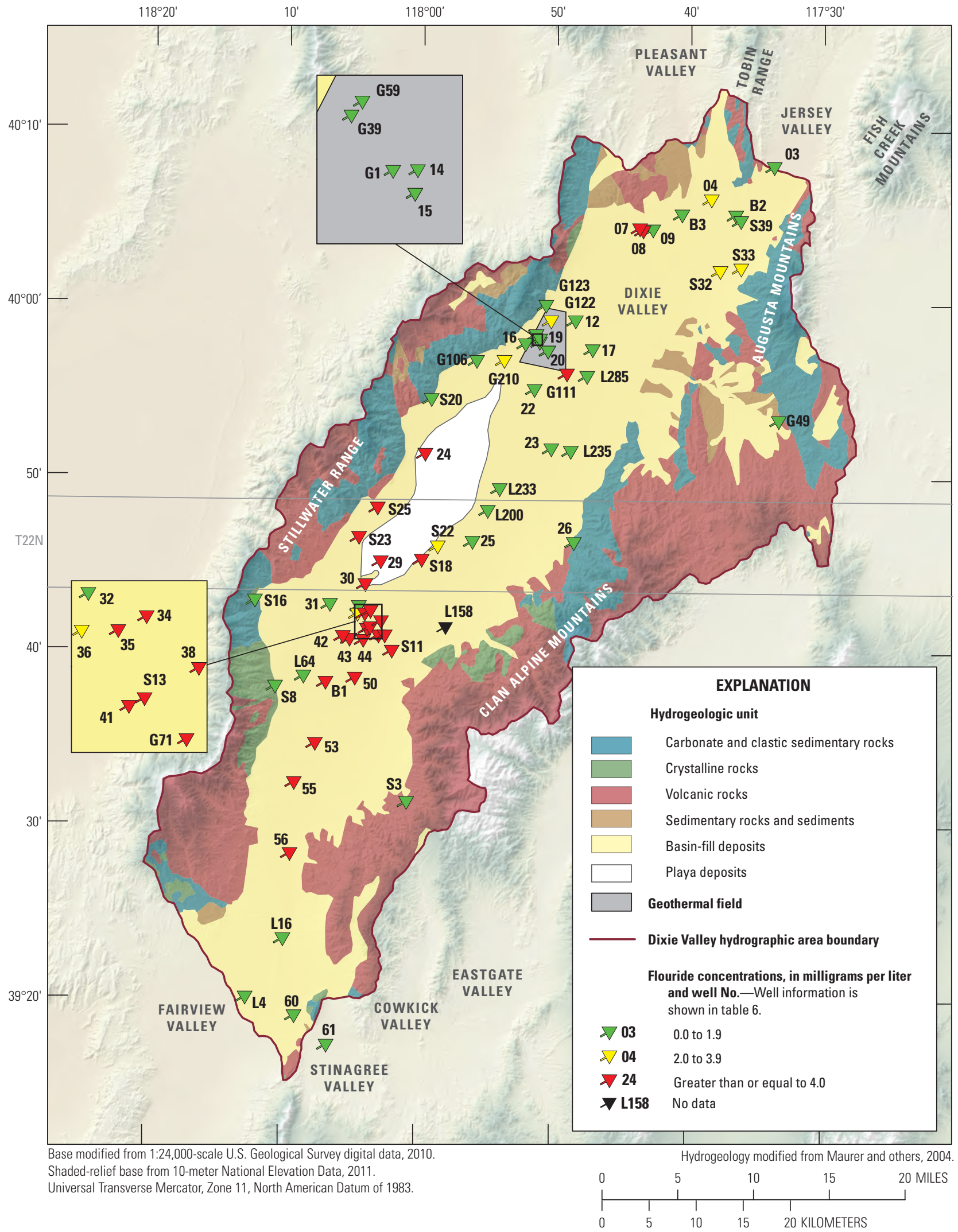

Figure 10. Fluoride concentrations in groundwater from sites and maximum contaminant level (MCL) exceedances in the basin-fill aquifer, Dixie Valley, west-central Nevada. National MCL is 4 milligrams per liter (U.S. Environmental Protection Agency, 2009), Nevada State MCL is 2 milligrams per liter (Nevada Administrative code 445A.455). 


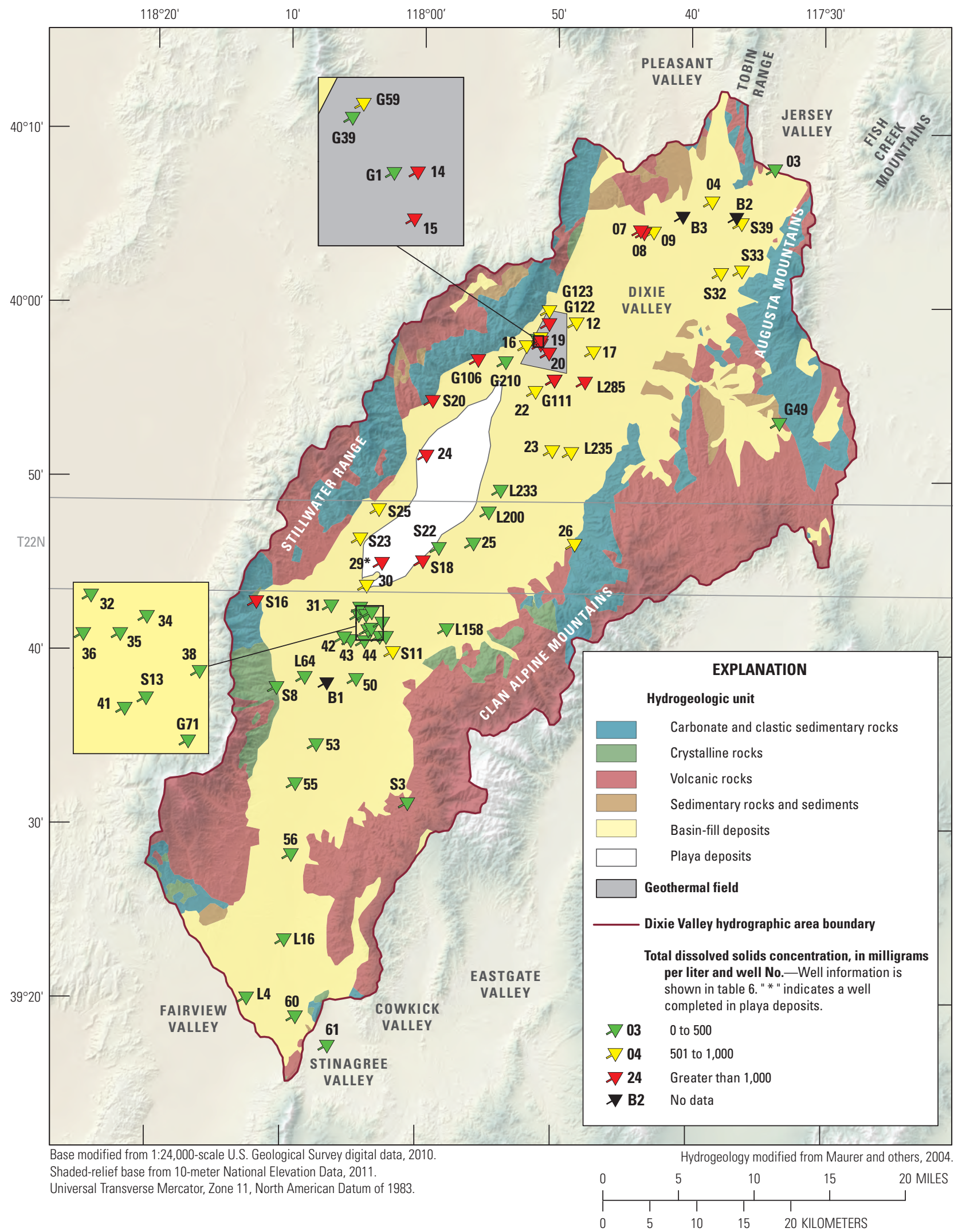

Figure 11. Total dissolved solids concentrations in groundwater from sites and secondary maximum contaminant level (SCML) exceedance distributions in the basin-fill aquifer, Dixie Valley, west-central Nevada. National SMCL is 500 milligrams per liter (U.S. Environmental Protection Agency, 2009), Nevada State SMCL is 1,000 milligrams per liter (Nevada Administrative code 445A.455). 
Tungsten does not have a national drinking water standard, but is an emerging contaminant of concern because of potential health effects to humans (National Institute for Occupational Safety and Health, 2005; U.S. Environmental Protection Agency, 2010). Concentrations of tungsten from 32 sites in the Dixie Valley basin fill aquifer range from 0.04 to $126 \mu \mathrm{g} / \mathrm{L}$, with a median concentration of $7.0 \mu \mathrm{g} / \mathrm{L}$. For comparison purposes, tungsten concentrations from 171 groundwater sites throughout Nevada ranged from less than 0.5 to $677 \mu \mathrm{g} / \mathrm{L}$, with a median concentration $=0.75 \mu \mathrm{g} / \mathrm{L}$ (U.S. Geological Survey, 2014). The median tungsten concentrations in Dixie Valley groundwater is more than nine times greater than the median concentrations in the rest of the state. Previous studies indicate that high soil $\mathrm{pH}$ can increase the solubility of tungsten, causing it to leach more readily into groundwater (Agency for Toxic Substances and Disease Registry, 2005; Association of State and Territorial Solid Waste Management Officials, 2008). Tungsten concentrations greater than $25 \mu \mathrm{g} / \mathrm{L}$ in Dixie Valley were measured in 25 percent of samples, and 75 percent of those had $\mathrm{pH}$ values of greater than 8.0 and were south of the playa. In the remainder of Nevada, 16 percent of samples had tungsten concentrations greater than $25 \mu \mathrm{g} / \mathrm{L}$ and 81 percent of those samples had a $\mathrm{pH}$ of 8.0 or greater.

Groundwater in playa deposits is chemically distinct from the fresh basin-fill aquifer (fig. 8), and 13 of 21 constituents analyzed for drinking water standards exceeded the standard, often by more than 300 percent (table 9 ). For all constituents of playa groundwater exceeding standards, concentrations of those constituents were greater than concentrations from all other sites sampled except iron, lead, manganese, and $\mathrm{pH}$. As would be expected at the terminus of a groundwater-flow system, the greatest exceedances typically occurred with increasing proximity to the playa because of the continued enrichment as groundwater moves along the flow path. For example, arsenic concentrations in groundwater collected from wells 26 (mountain front), 25 (mid-valley), and 29 (playa) (table 6; fig. 7) increase from 1.6 to 40.6 to 12,050 $\mu \mathrm{g} / \mathrm{L}$, respectively. With respect to national drinking water standards, groundwater approaching and in playa sediments would require considerable treatment before it would be considered potable.

\section{Seasonal Changes in Groundwater Chemistry}

Seasonal changes in groundwater chemistry were evaluated from 11 wells initially sampled in autumn 2009, and again in spring 2010. Constituent concentrations were considered to vary seasonally if the relative difference in autumn and spring concentrations was equal to or greater than 15 percent (table 10). About two-thirds of the constituents analyzed changed by less than 15 percent between sampling periods, whereas one-third either increased or decreased by more than 15 percent.

Iron and manganese concentrations decreased (by an average of about 70 and 90 percent, respectively) at about one-half of the sites sampled, whereas lithium concentrations increased (by an average of about 40 percent) at 10 of the 11 sites (table 10). Increases in lithium corresponding to decreases in magnesium could suggest an influx of geothermal water into the basin-fill aquifer (see section, "Connection between Basin-Fill and Geothermal Aquifers”). At well 30, however, corresponding decreases in arsenic concentrations and water temperature indicate geothermal mixing is unlikely because geothermal water typically has high arsenic concentrations and warm temperatures.

Fluctuations of trace metals concentrations (including arsenic, fluoride, lithium, manganese, and tungsten) in groundwater samples collected from well 26 on the Clan Alpine Mountains alluvial fan (table 10; fig. 7) were larger than would be expected from such an upgradient site. Greater arsenic and fluoride concentrations in spring 2010 samples than in autumn 2009 samples could represent interactions between winter mountain-front recharge and volcanic rocks containing arsenic and fluoride. A tungsten mining prospect just south of well 26 and in the Clan Alpine Mountains (Willden and Speed, 1974, p. 58) could be the source of tungsten with a higher springtime water table possibly releasing loosely bound ions from clays and other sediments, thereby enriching the local groundwater.

\section{Connection between Basin-Fill and Geothermal Aquifers}

Multiple geothermal groundwater reservoirs are present beneath the basin-fill aquifer in Dixie Valley to estimated depths of 20,000 ft bls (Blackwell and others, 2003; McKenna and Blackwell, 2004; Wisian and Blackwell, 2004). In addition to the established geothermal field north of the playa, many other geothermal features exist in other areas of Dixie Valley including many warm and hot springs (fig. 5) and wells (fig. 7) in northern Dixie Valley, the Dixie Valley hot spring complex (fig. 5; S23, S25, and S28) along the Stillwater Fault west of the playa, and warm groundwater south of the playa (in the vicinity of site 55; fig. 7). In its basic composition, geothermal water is heated meteoric water that has undergone distinctive chemical changes caused by water-rock interactions induced by temperatures of as much as $300{ }^{\circ} \mathrm{C}$ (Ellis and Mahon, 1977; Giggenbach, 1992). These chemical changes make geothermal water chemically distinct from cold meteoric-derived groundwater, and, therefore, allow the evaluation of mixing between hot and relatively cold meteoric-derived groundwater. 
Table 10. Selected chemical constituent concentration and percentage of change for samples collected in Dixie Valley, west-central Nevada, October 2009 and May 2010.

[Relative percent increase or decrease in constituent concentrations between autumn and spring sampling periods was used to classify constituents as constant (less than plus or minus 15 percent) or changing (greater than or equal to plus or minus 15 percent). Values highlighted in green are greater than or equal to plus 15 percent, and values highlighted in blue are greater than or equal to minus 15 percent. A bbreviations: ${ }^{\circ} \mathrm{C}$, degrees Celsius; $\mathrm{mg} / \mathrm{L}, \mathrm{milligram}$ per liter; $\mu \mathrm{g} / \mathrm{L}$, microgram per liter; -, no data]

\begin{tabular}{|c|c|c|c|c|c|c|c|c|c|c|c|}
\hline \multirow{3}{*}{$\begin{array}{l}\text { Chemical } \\
\text { constituent }\end{array}$} & \multirow{3}{*}{$\begin{array}{c}\text { Unit of } \\
\text { measure }\end{array}$} & \multicolumn{10}{|c|}{ Northern well No. } \\
\hline & & \multicolumn{2}{|c|}{04} & \multicolumn{2}{|c|}{07} & \multicolumn{2}{|c|}{19} & \multicolumn{2}{|c|}{22} & \multicolumn{2}{|c|}{23} \\
\hline & & $\begin{array}{c}2009 \\
\text { concen- } \\
\text { tration }\end{array}$ & $\begin{array}{c}2010 \\
\text { percent } \\
\text { change }\end{array}$ & $\begin{array}{c}2009 \\
\text { concen- } \\
\text { tration }\end{array}$ & $\begin{array}{c}2010 \\
\text { percent } \\
\text { change }\end{array}$ & $\begin{array}{c}2009 \\
\text { concen- } \\
\text { tration }\end{array}$ & $\begin{array}{c}2010 \\
\text { percent } \\
\text { change }\end{array}$ & $\begin{array}{c}2009 \\
\text { concen- } \\
\text { tration }\end{array}$ & $\begin{array}{c}2010 \\
\text { percent } \\
\text { change }\end{array}$ & $\begin{array}{c}2009 \\
\text { concen- } \\
\text { tration }\end{array}$ & $\begin{array}{c}2010 \\
\text { percent } \\
\text { change }\end{array}$ \\
\hline Temperature & ${ }^{\circ} \mathrm{C}$ & 17.5 & 4 & 25.4 & -27 & 15.2 & 1 & 15.5 & 5 & 15.4 & - \\
\hline $\mathrm{pH}$ & $\mathrm{pH}$ & 7.4 & 1 & 7.4 & 0 & 7.8 & -3 & 7.8 & 0 & 7.6 & 1 \\
\hline TDS & $\mathrm{mg} / \mathrm{L}$ & 910 & -2 & 1,070 & 1 & 3,580 & 18 & 776 & -1 & 658 & -0 \\
\hline Calcium & $\mathrm{mg} / \mathrm{L}$ & 64.5 & -5 & 102 & 5 & 112 & -4 & 39.2 & -4 & 57.1 & 3 \\
\hline Magnesium & $\mathrm{mg} / \mathrm{L}$ & 31 & -12 & 24.8 & -3 & 95.5 & -2 & 22.2 & -5 & 44.4 & 0 \\
\hline Sodium & $\mathrm{mg} / \mathrm{L}$ & 201 & -7 & 166 & 1 & 1,020 & 7 & 157 & -8 & 76.5 & 4 \\
\hline Potassium & $\mathrm{mg} / \mathrm{L}$ & 26.2 & -2 & 34.5 & -1 & 28.3 & -1 & 19.8 & -5 & 7.7 & 4 \\
\hline Bicarbonate & $\mathrm{mg} / \mathrm{L}$ & 544 & 3 & 333 & -7 & 340 & 6 & 284 & 1 & 240 & -2 \\
\hline Sulfate & $\mathrm{mg} / \mathrm{L}$ & 151 & -4 & 374 & 2 & 337 & 9 & 156 & 1 & 155 & 1 \\
\hline Chloride & $\mathrm{mg} / \mathrm{L}$ & 84.6 & -9 & 74.8 & 2 & 1,730 & 20 & 123 & 2 & 107 & 0 \\
\hline Arsenic & $\mu \mathrm{g} / \mathrm{L}$ & 9 & 17 & 13.8 & 12 & 31.8 & 13 & 40 & -13 & 10 & 11 \\
\hline Boron & $\mu \mathrm{g} / \mathrm{L}$ & 2,130 & -5 & 1,740 & -49 & 2,570 & 17 & 1,050 & 4 & 297 & -1 \\
\hline Bromine & $\mathrm{mg} / \mathrm{L}$ & 0.2 & -12 & 0.1 & 0 & 1.1 & 0 & 0.22 & -15 & 0.2 & -6 \\
\hline Fluoride & $\mathrm{mg} / \mathrm{L}$ & 2.2 & -6 & 4.7 & 0 & 1.2 & 9 & 1.41 & 3 & 0.3 & 10 \\
\hline Iron & $\mu \mathrm{g} / \mathrm{L}$ & 73 & -92 & 11 & 43 & 1,050 & -3 & 6 & 0 & 6 & -40 \\
\hline Lithium & $\mu \mathrm{g} / \mathrm{L}$ & 488 & 21 & 604 & -8 & 844 & 54 & 235 & 40 & 31 & 35 \\
\hline Manganese & $\mu \mathrm{g} / \mathrm{L}$ & 5.9 & -68 & 2.9 & 32 & 742 & 1 & 45.2 & -4 & 2.6 & -115 \\
\hline Nitrogen & $\mathrm{mg} / \mathrm{L}$ & 4 & -39 & 0.4 & 123 & & - & 0.03 & 11 & 0.4 & -3 \\
\hline Silica & $\mathrm{mg} / \mathrm{L}$ & 59.7 & 1 & 73.7 & -1 & 58.5 & -2 & 82.2 & -3 & 64 & 0 \\
\hline Tungsten & $\mu \mathrm{g} / \mathrm{L}$ & 1.5 & -31 & 18.4 & 9 & 8.6 & 14 & 31.4 & -12 & 0.8 & 0 \\
\hline Uranium & $\mu \mathrm{g} / \mathrm{L}$ & 2.8 & 1 & 0.9 & -11 & 0.2 & 10 & 4.6 & 1 & 6.0 & 1 \\
\hline
\end{tabular}

\begin{tabular}{|c|c|c|c|c|c|c|c|c|c|c|c|c|c|}
\hline \multirow{3}{*}{$\begin{array}{l}\text { Chemical } \\
\text { constituent }\end{array}$} & \multirow{3}{*}{$\begin{array}{c}\text { Unit of } \\
\text { measure }\end{array}$} & \multicolumn{12}{|c|}{ Southern well No. } \\
\hline & & \multicolumn{2}{|c|}{25} & \multicolumn{2}{|c|}{26} & \multicolumn{2}{|c|}{30} & \multicolumn{2}{|c|}{31} & \multicolumn{2}{|c|}{38} & \multicolumn{2}{|c|}{42} \\
\hline & & $\begin{array}{c}2009 \\
\text { concen- } \\
\text { tration }\end{array}$ & $\begin{array}{c}2010 \\
\text { percent } \\
\text { change }\end{array}$ & $\begin{array}{c}2009 \\
\text { concen- } \\
\text { tration }\end{array}$ & $\begin{array}{c}2010 \\
\text { percent } \\
\text { change }\end{array}$ & $\begin{array}{c}2009 \\
\text { concen- } \\
\text { tration }\end{array}$ & $\begin{array}{c}2010 \\
\text { percent } \\
\text { change }\end{array}$ & $\begin{array}{c}2009 \\
\text { concen- } \\
\text { tration }\end{array}$ & $\begin{array}{c}2010 \\
\text { percent } \\
\text { change }\end{array}$ & $\begin{array}{c}2009 \\
\text { concen- } \\
\text { tration }\end{array}$ & $\begin{array}{c}2010 \\
\text { percent } \\
\text { change }\end{array}$ & $\begin{array}{c}2009 \\
\text { concen- } \\
\text { tration }\end{array}$ & $\begin{array}{c}2010 \\
\text { percent } \\
\text { change }\end{array}$ \\
\hline Temperature & ${ }^{\circ} \mathrm{C}$ & 15.3 & -3 & 16.7 & -4 & 15.8 & -22 & 15.4 & -3 & 20 & -3 & 19.4 & 2 \\
\hline $\mathrm{pH}$ & $\mathrm{pH}$ & 7.9 & 1 & 7.8 & -3 & 9.8 & 0 & 8.2 & -1 & 7.3 & 13 & 8.4 & -5 \\
\hline TDS & $\mathrm{mg} / \mathrm{L}$ & 478 & 1 & 658 & 0 & 683 & -1 & 298 & 1 & 342 & -5 & 306 & 6 \\
\hline Magnesium & $\mathrm{mg} / \mathrm{L}$ & 11.4 & 3 & 59.4 & -5 & 0.5 & -16 & 2.7 & -7 & 1.1 & -6 & 2.0 & 0 \\
\hline Sodium & $\mathrm{mg} / \mathrm{L}$ & 84 & 4 & 90 & -4 & 224 & 3 & 43 & -7 & 66.9 & 2 & 61.8 & -1 \\
\hline Potassium & $\mathrm{mg} / \mathrm{L}$ & 5.0 & 0 & 2.2 & -3 & 1.96 & -5 & 3.9 & -2 & 4.6 & 3 & 3.9 & 4 \\
\hline Bicarbonate & $\mathrm{mg} / \mathrm{L}$ & 145 & -7 & 390 & 0 & 202 & 24 & & - & & - & & - \\
\hline Sulfate & $\mathrm{mg} / \mathrm{L}$ & 81.9 & 2 & 145 & 0 & 85.2 & 0 & 50 & 0 & 74.4 & 0 & 76.6 & -1 \\
\hline Chloride & $\mathrm{mg} / \mathrm{L}$ & 95.8 & 4 & 76.6 & -1 & 28.7 & 1 & 28.6 & 6 & 22.3 & 2 & 24 & 2 \\
\hline Iron & $\mu \mathrm{g} / \mathrm{L}$ & 3 & 67 & 12 & 8 & 1,910 & -19 & 22 & -59 & 39.0 & -147 & 3 & 29 \\
\hline Lithium & $\mu \mathrm{g} / \mathrm{L}$ & 30.8 & 40 & 25.4 & 45 & 6.6 & 41 & 32.2 & 39 & 51.5 & 30 & 28.4 & 41 \\
\hline Manganese & $\mu \mathrm{g} / \mathrm{L}$ & 0.3 & 29 & 2.8 & 83 & 66.4 & -12 & 0.8 & -67 & 1.3 & -171 & 0.3 & -40 \\
\hline Nitrogen & $\mathrm{mg} / \mathrm{L}$ & 0.5 & -6 & 0.22 & -5 & 0.02 & 0 & 0.8 & 0 & 0.1 & 1 & 0.3 & -1 \\
\hline Silica & $\mathrm{mg} / \mathrm{L}$ & 53.5 & 0 & 15.9 & -1 & 67.1 & -5 & 54.7 & 0 & 67.3 & -2 & 55.7 & 0 \\
\hline Tungsten & $\mu \mathrm{g} / \mathrm{L}$ & 12.3 & -3 & 0.02 & 100 & 55.5 & 6 & 3 & -3 & 27.5 & 12 & 6.4 & 21 \\
\hline Uranium & $\mu \mathrm{g} / \mathrm{L}$ & 4.0 & 4 & 4.27 & -4 & 0.2 & 0 & 3.7 & 3 & 0.8 & 10 & 0.5 & 9 \\
\hline
\end{tabular}


The Dixie Valley geothermal field (fig. 1) was studied extensively in the late 1990s and early 2000s to evaluate the geothermal resource (for example, Goff and others, 2002) and to understand losses in fluid pressures caused by geothermal water extraction (Benoit and others, 2000). One goal of this research was to determine the extent to which the geothermal and cold-basin-fill aquifers were connected. One conclusion, based on limited isotopic and chemical information, indicated that the geothermal and basin-fill water originated almost exclusively from downward percolation of Pleistocene Lake Dixie water as the climate warmed, and not from mountain recharge (Nimz and others, 1999; Gregory Nimz, Lawrence Livermore National Laboratory [retired], written commun., 2012). Carbon-14 ages of 12-20 thousand years for the geothermal and basin-fill waters, respectively, appear to be consistent with this interpretation. Stable hydrogen and oxygen isotopic data, radiochemical chlorine-36 data, and comparisons of the chemical composition of geothermal and basin-fill aquifer water indicated almost no mountain-front recharge to either aquifer and that the chemical composition of the basin-fill groundwater was derived from water-rock interaction with underlying Mesozoic carbonates (Nimz and others, 1999). However, in contrast to the results of Nimz and others (1999), a study by Campana and others (1986) comparing stable isotopic signatures and chloride concentrations concluded that geothermal and basin-fill groundwater in Dixie Valley has not evaporated extensively, and likely originates from snowmelt and mountain-block recharge. Simulation results from a mixing model developed by Bruton and others (1997) indicated that the basin-fill aquifer could contain as much as 15 to 25 percent geothermal water in the geothermal field area north of the Dixie Valley playa (fig. 7).

With the availability of additional, more spatially extensive groundwater chemistry data representative of the basin-fill aquifer, a reassessment of the interaction between geothermal and basin-fill aquifer water was possible. The purpose of this reevaluation was to determine if the interaction of shallow basin-fill groundwater with the deeper geothermal aquifer fits the previously determined mixing model of Bruton and others (1997) in areas of Dixie Valley outside the established geothermal field.

In order to contrast the geothermal and basin-fill aquifers, selected geothermal data published in Goff and others (2002) and the Great Basin Center for Geothermal Energy (2009) were compared to recent basin-fill groundwater samples collected for this study. Groundwater samples were divided into three classes based on field temperature measurements for the purposes of this study (fig. 7). Groundwater with a temperature of less than $20^{\circ} \mathrm{C}$ was considered cold-basinfill groundwater based on generally observed groundwater temperatures in Nevada. Water with a field temperature of $20-50{ }^{\circ} \mathrm{C}$ was considered warm groundwater, or potentially influenced by geothermal water; groundwater with a field temperature of greater than $50{ }^{\circ} \mathrm{C}$ was considered geothermal water, or heavily influenced by geothermal water. The upper limit of $50{ }^{\circ} \mathrm{C}$ was selected to describe geothermal water based on a study by Schaefer and others (2005) that concluded groundwater temperatures of as much as roughly $50{ }^{\circ} \mathrm{C}$ could be attributed to travel along deep, long flow paths that did not require geothermal heating. Schaefer and others (2005) assumed that to reach temperatures of greater than $50{ }^{\circ} \mathrm{C}$ required geothermal input based on the geothermal gradients in the region. Although water temperatures in the shallow basin-fill aquifer sampled in this study were less than $50{ }^{\circ} \mathrm{C}$, the wells sampled were much shallower, and the flow paths were much shorter than those sampled by Schaefer and others (2005). Therefore, water temperatures between 20 and $50{ }^{\circ} \mathrm{C}$ likely indicate mixing between geothermal and meteoric-derived groundwater, and not heating derived from deep, long flow paths. The basin-fill aquifer sites sampled for this study also were divided into these groundwater designations. The warmest basin-fill groundwater sampled during this study was $41.4^{\circ} \mathrm{C}$ (site 55).

Warm groundwater temperature designations may not necessarily represent influence from a geothermal source. For example, groundwater collected from the playa was $21.4^{\circ} \mathrm{C}$ (table 6, well 29) and, therefore, is considered warm water. Warm playa water temperatures are likely due to measurements near the playa surface in November, after warming all summer and prior to much cooling in the autumn and winter, rather than mixing with geothermal water. Nevertheless, these temperature designations allow the establishment of a simple gradient between water likely to be less influenced by mixing with geothermal water and water more likely to be mixed with geothermal water.

As previously stated in section, "Chemical Composition of the Basin-Fill Aquifer," the limitations of using multiple data sources include the type of supplemental data available such as well construction and techniques used during sample collection and analysis (Goff and others, 2002; Great Basin Center for Geothermal Energy, 2009). First, information on well construction is needed to evaluate chemical gradients and composition differences between neighboring wells because these differences could be related to groundwater sampling depth. Second, documentation of any losses of gas or water during the collection of samples from geothermal wells and springs by degassing or steam is important when comparing to data from cold water because loss of water vapor concentrates the sample; this documentation was not always apparent in the sample site descriptions. Finally, the same parameters measured in this study were not always measured in early studies, making comparisons among datasets difficult. 


\section{Geothermal and Non-Geothermal Indicators}

Several chemicals have been used previously to indicate groundwater heating under geothermal conditions (Kharaka and Mariner, 1989). These chemicals are lithium, boron, silica, rubidium, and antimony. Conditions often associated with geothermal conditions are groundwater temperatures greater than $50{ }^{\circ} \mathrm{C}$ and low magnesium concentrations. Under these circumstances, relatively high groundwater temperatures can create an environment where magnesium has a lower solubility and reacts to form clay minerals (Gunnlaugsson, 2008). Dixie Valley geothermal water has low concentrations of magnesium, ranging from below detection to less than $0.1 \mathrm{mg} / \mathrm{L}$, likely owing to the reaction of magnesium with host rocks to create altered minerals such as magnesiumsilicates and clays. Dixie Valley geothermal groundwater also has high sodium and chloride concentrations, but evaporated, or old (thousands of years) basin-fill groundwater also will have high concentrations of sodium and chloride that are not caused by high temperatures. Ratios of magnesium, sodium, and potassium can be used to determine the presence of geothermal groundwater and to calculate the geothermal reservoir temperature from which the water was derived (Kharaka and Mariner, 1989). In this study, groundwater temperature and concentrations of lithium (appendix B), boron, and magnesium were used as geothermal indicators; silica (silicon dioxide, $\mathrm{SiO}_{2}$ ) also was used.

Just as some chemicals are indicators of geothermally heated water, other chemicals are indicative of non-geothermal water. High concentrations of magnesium is an indicator of non-geothermal groundwater and can result from either magnesium carbonates (dolomite, hydromagnesite, or magnesite) or mafic (basalt) rock in the groundwater-flow path (Hounslow, 1995). Groundwater sampled east of the Dixie Valley playa was enriched in magnesium relative to the rest of the basin (fig. 12), likely owning to basalt in the Clan Alpine Mountains. Several sites near the geothermal plant indicate high magnesium concentrations and although well depth information is not available for all sites, most high magnesium concentrations are associated with shallow basin-fill wells.

High sulfate and bromide concentrations also might indicate non-geothermal waters, as well as waters that have low TDS.

High silica concentrations often are indicative of geothermal mixing with cold groundwater, but the presence of both crystalline and non-crystalline silica in Dixie Valley confounds the use of this indicator. For example, concentrations of silica greater than $30 \mathrm{mg} / \mathrm{L}$ can be indicative of geothermal water in cold groundwater. At typical geothermal reservoir temperatures $\left(200-300^{\circ} \mathrm{C}\right)$, silica is highly soluble and concentrations in geothermal water can exceed $500 \mathrm{mg} / \mathrm{L}$. Dixie Valley geothermal water has silica concentrations ranging from 100 to $700 \mathrm{mg} / \mathrm{L}$. Quartz (crystalline silica) is very resistant to chemical weathering at non-geothermal temperatures (less than $50^{\circ} \mathrm{C}$ ) and usually has concentrations of less than $10 \mathrm{mg} / \mathrm{L}$ (Hounslow, 1995).
Non-crystalline or poorly crystalline silica is present in volcanic deposits such as tuffs in Dixie Valley, which are less stable and are more easily weathered. Therefore, cold groundwater that has flowed through tuff deposits might have concentrations of silica greater than $30 \mathrm{mg} / \mathrm{L}$. Silica concentrations for 86 percent of groundwater samples collected during this study were greater than $30 \mathrm{mg} / \mathrm{L}$. Therefore, high silica concentrations were not necessarily indicative of geothermal mixing with basin-fill groundwater.

\section{Mixing of Geothermal and Basin-Fill Groundwater}

\section{Chemical Indicators}

In order to determine the extent of mixing between geothermal and basin-fill aquifer groundwater, end-members (waters that are not mixed) were established. Dixie Valley geothermal water generally is distinct in chemical composition from cool basin-fill groundwater. Water collected from geothermal production wells (as provided by Goff and others [2002], and Zehner and others [2006]) was sufficient to be used as the geothermal end-member. The main chemical indicators of geothermal water used in this study were high lithium, silica, and boron.

Basin-fill groundwater (the other end-member), derived from either Pleistocene recharge from Lake Dixie or mountain-front recharge, is less clearly defined because of varying lithologies around the basin. Although waterrock interaction with basalts, granites, limestone and other less-abundant rock types lead to a mixture of weathering products, diagenetic alterations, and complex ions in solution, certain weathering characteristics of some lithologies make it feasible to determine a general basin-fill end-member.

The molar ratio of magnesium to lithium was used to characterize geothermal groundwater in Dixie Valley. Data used to evaluate the geothermal nature of groundwater showed a strong correlation between low magnesium-to-lithium ratios and high geothermal silicon concentrations, which indicates that geothermal fluids are sufficiently identified by the magnesium-to-lithium ratio (fig. 13). Groundwater samples collected for this study show a similar pattern between magnesium-to-lithium ratios and dissolved-silica concentrations (fig. 14). Most non-geothermal groundwater has higher magnesium-to-lithium ratios than warm or hot water. Cooler basin-fill aquifer water shows the least mixing, but some samples from this study and from historical analyses show mixing.

High concentrations of boron and lithium in groundwater are mostly derived from geothermal heating (Giggenbach, 1992; Hounslow, 1995). The relation of boron and lithium between cold groundwater and geothermal fluids is shown in figure 15. Even the lowest concentrations of boron and lithium generally occur along a mixing line between concentrated geothermal fluids and dilute cold groundwater (fig. 15, inset). 


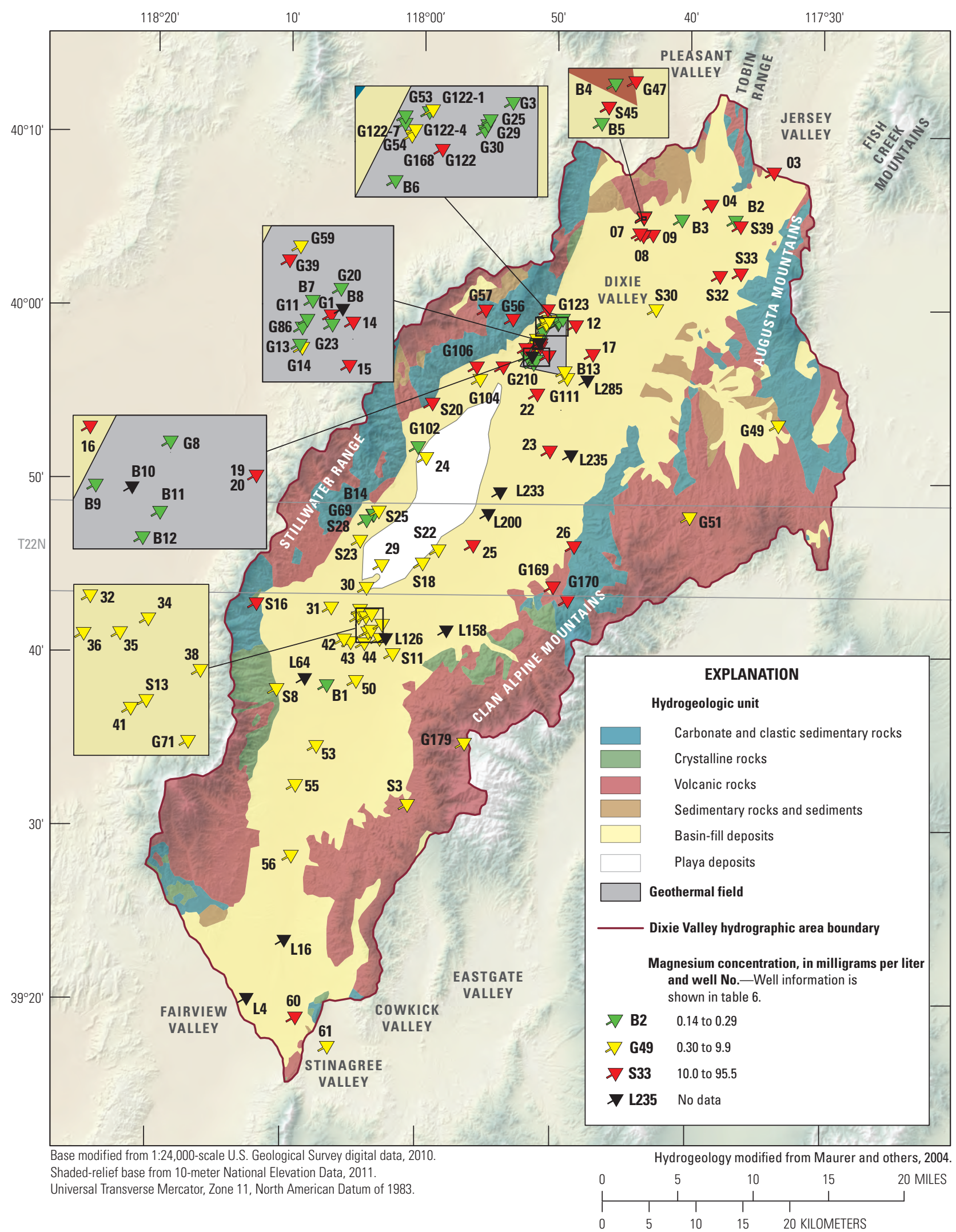

Figure 12. Magnesium concentrations in groundwater from sites in Dixie Valley, west-central Nevada. Magnesium concentrations are higher on east side of basin than in other areas. 


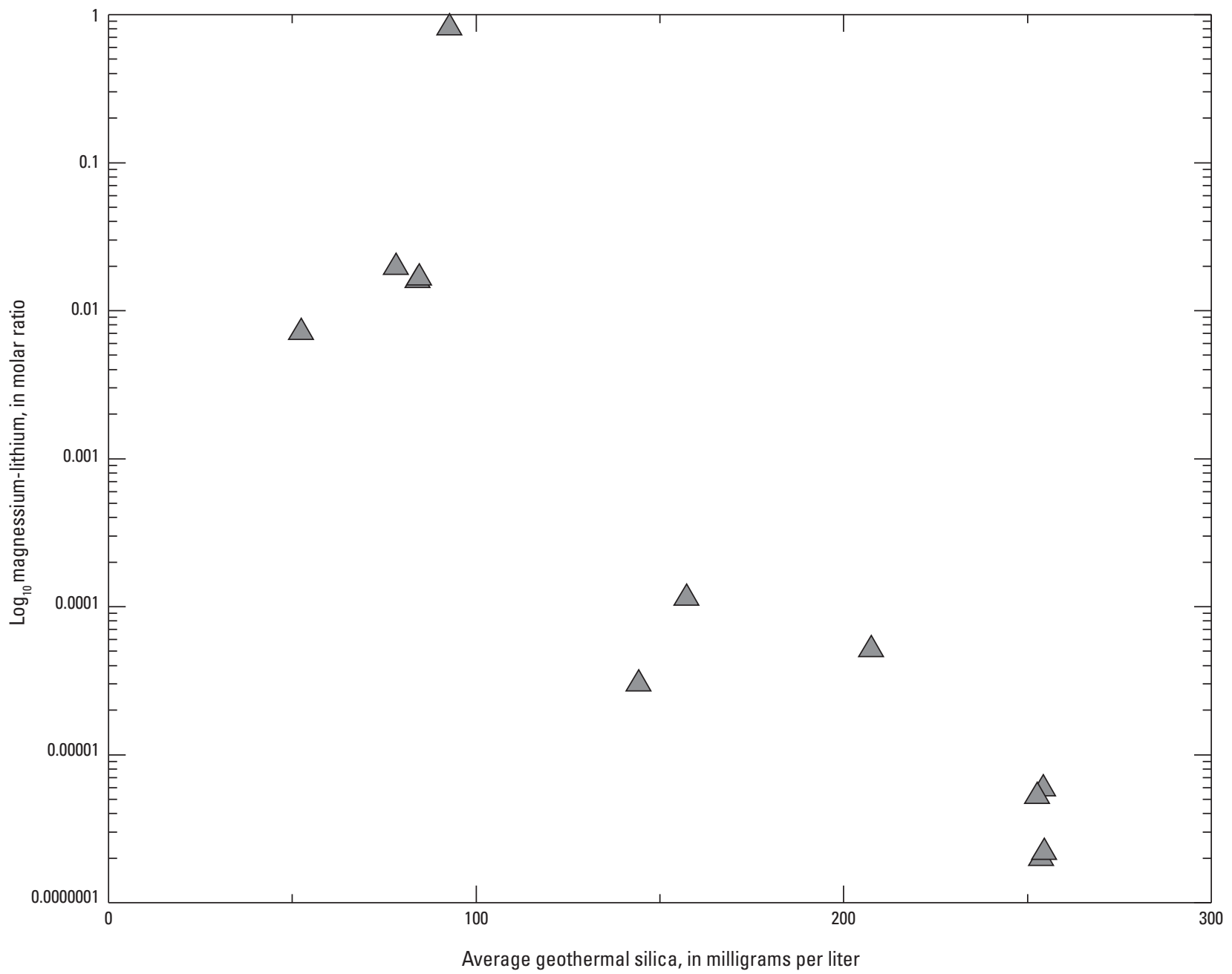

Figure 13. Relation between the molar ratio of magnesium to lithium and average geothermal silicon in geothermal groundwater samples, Dixie Valley, west-central Nevada.

The correlation, (coefficient of determination, $\mathrm{r}^{2}=0.56$ ) estimated from a sample size of 138 paired boron and lithium analyses is significant at the 1-percent level ( $p$-value $<0.0001$ ). The relatively consistent increase of lithium and boron indicates that there is a connection between the geothermal and cold groundwater systems. Variations in the boron and lithium correlation can be attributed to many factors that may include, but are not limited to, differences in groundwater chemistry from various rock-water interaction rates with different lithologies throughout the basin, differences in rainfall and snowmelt during the sampling period (more than 20 years), and differences in laboratory analyses methods through time.

Determining the amount of mixing between geothermal water and cold basin-fill groundwater is difficult to quantify because of a lack of distinct end-member solutions; however, by using different lines of evidence, it is possible to show relatively consistent amounts of mixing. Lithium concentrations in the geothermal production wells range from about $350 \mu \mathrm{g} / \mathrm{L}$ to as much as 2,820 $\mu \mathrm{g} / \mathrm{L}$ (Goff and others, 2002), although the average lithium concentration of geothermal wells is $2,245 \mu \mathrm{g} / \mathrm{L}$. The average lithium concentration of the cold basin-fill groundwater (water that had a temperature when sampled of less than $20^{\circ} \mathrm{C}$ and is not influenced by nearby geothermal sources) is $51 \mu \mathrm{g} / \mathrm{L}$. If linear mixing is used and it is assumed that any lithium in a water sample greater than $51 \mu \mathrm{g} / \mathrm{L}$ is derived from geothermal fluids, every additional $100 \mu \mathrm{g} / \mathrm{L}$ of lithium would represent 4.5 percent mixing with a geothermal fluid. Twenty-seven of 51 (or about 53 percent of) basin-fill wells and springs sampled had lithium concentrations greater than $51 \mu \mathrm{g} / \mathrm{L}$, indicating that mixing of as much as 46 percent was possible, although average mixing was 13 percent. This is a somewhat crude method for determining mixing between the cold groundwater and geothermal fluids, but because end-member solutions are not well constrained, these approximations are the best estimates. 


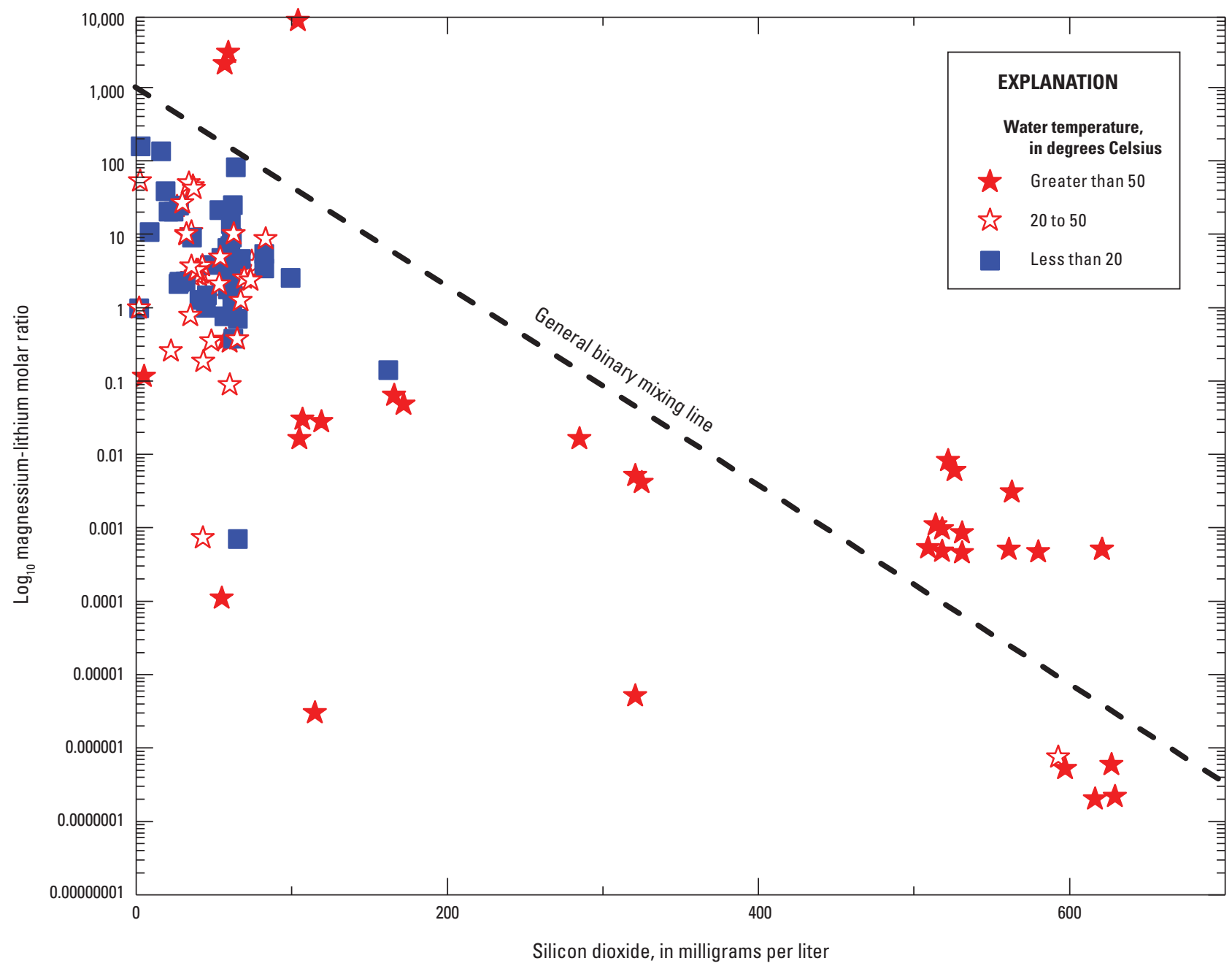

Figure 14. Mixing between water high in silica $\left(\mathrm{SiO}_{2}\right)$ and lithium (Li) with water high in magnesium $(\mathrm{Mg})$ and low in $\mathrm{SiO}_{2}$ and $\mathrm{Li}$, and water temperature, Dixie Valley, west-central Nevada. Water samples include current basin-fill groundwater and historical basin-fill and geothermal groundwater.

The highest concentrations of geothermally derived constituents (lithium, silica, boron, and temperature) generally are present in the northern, western, and southern areas of the basin, near known faults or geothermal features (lithium, fig. 16; temperature, fig. 7). High magnesium concentrations derived from the weathering of volcanic rocks mostly are present in the eastern and northern parts of the basin (fig. 12). Groundwater in the southern and northern parts of the basin likely is mixed with local geothermal water present in these areas, and not from mixing with geothermal water transported through the basin-fill aquifer from near the Dixie Valley Geothermal Power Plant. Some of the spatial variations in concentrations might be due to differences in well depth between the samples.

\section{Geothermometry}

Several methods have been developed to determine the temperature from which geothermal fluids or heated groundwater originated. These methods (geothermometry) usually are used to estimate reservoir temperatures of deep geothermal aquifers, but these methods also can be used to estimate how hot the water was originally at depth for warm groundwater sampled near the surface. These methods use formulas for key geothermal indicator elements based on feldspar equilibrium (sodium, potassium, and calcium). Other methods involve silica equilibrium and (or) magnesium and lithium empirical equations (Kharaka and Mariner, 1989). 


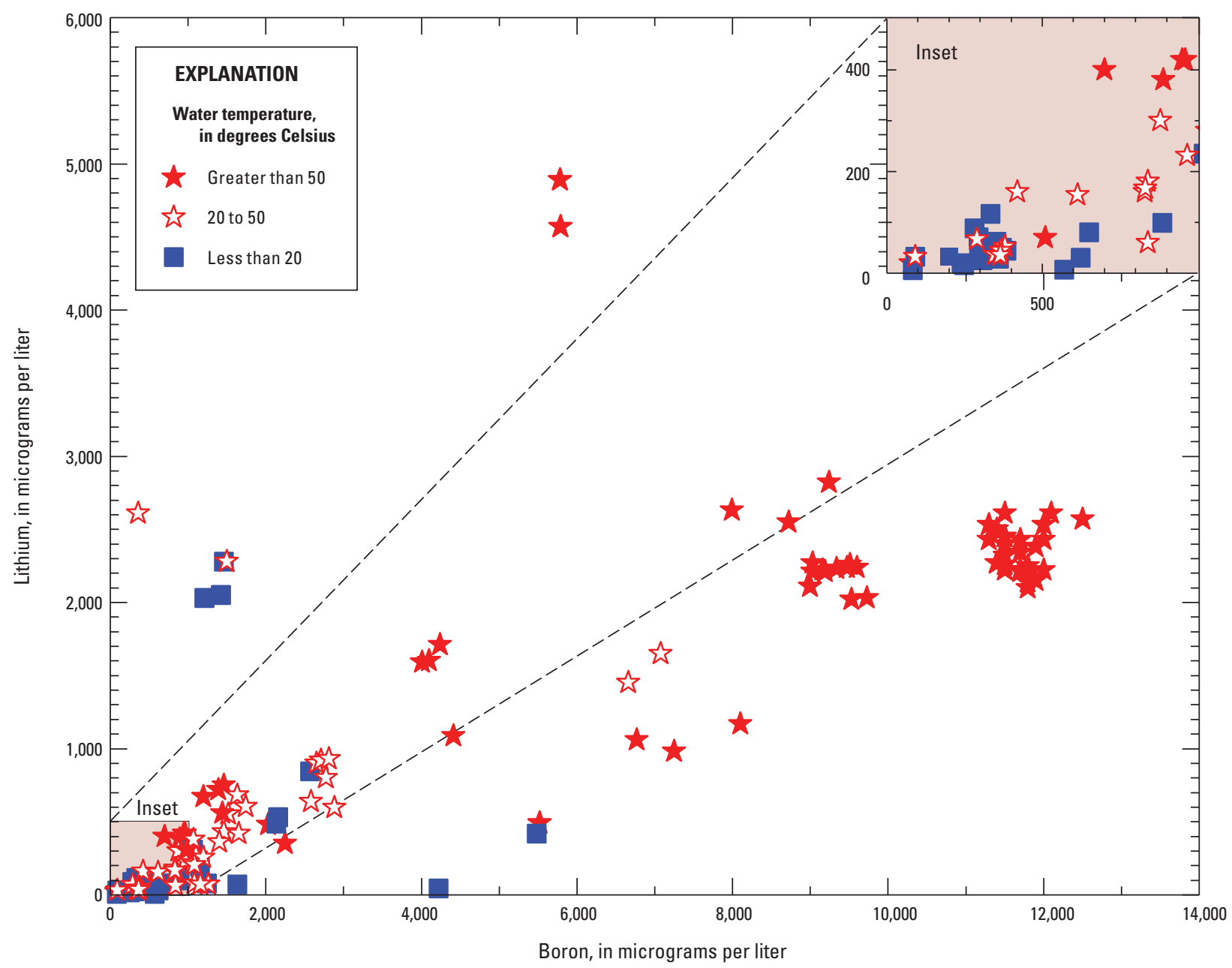

Figure 15. Relation between boron and lithium concentrations, and water temperature in basin-fill groundwater samples collected in this study and in historical basin-fill and geothermal groundwater samples, Dixie Valley, west-central Nevada. Coefficient of determination $\left(\mathrm{r}^{2}\right)$ equals 0.56 , and $\mathrm{p}$-value is less than 0.0001 .

Geothermometry methods also can be used to determine sources of heating (long flow paths compared to geothermal sources) in groundwater (Schaefer and others, 2005). When geothermometry is used, it is assumed that the chemistry of the water is in equilibrium with the heating that occurred at depth. For geothermal fluids, this generally is true because the fluids have little opportunity to interact with host rock because many geothermal fluids travel through fractures in the rock rather than through interconnected pores. For heated basin-fill aquifer water, longer flow paths, longer residence time in the aquifer, and greater contact with rock materials in matrix pores potentially allow for non-equilibrium dissolution or precipitation of some elements and compounds used in geothermometry. This means that multiple geothermometers should be used and care should be taken when evaluating temperatures calculated from equilibrium-based geothermometers in basin-fill aquifers (Land and MacPherson, 1992). For example, various parts of the basin in Dixie Valley have undergone different chemical reactions in the groundwater because of the heterogeneity of the aquifer rocks in the basin. Therefore, a geothermometer that might be useful in one part of the basin may not be useful everywhere in the basin. Because of disequilibrium reactions involving feldspar that can occur in alluvial basins, the magnesium-lithium geothermometer was selected as the most useful approach for this study (Land and MacPherson, 1992). However, comparison with other geothermometers were made to check the results and to evaluate areas that may have been affected by additions or subtractions of lithium or magnesium because of water-rock interactions involving clays or volcanic rocks in the basin (table 11). 


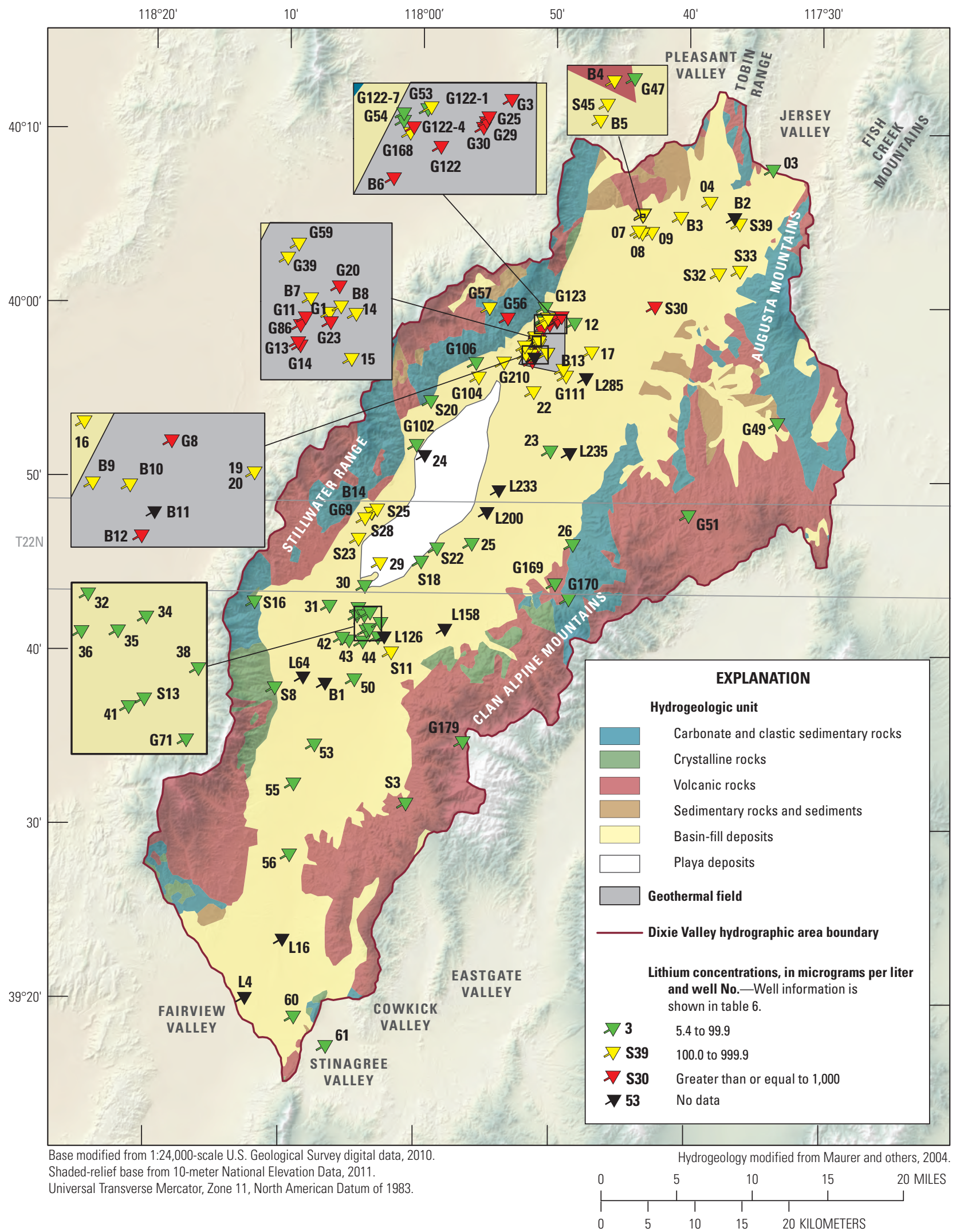

Figure 16. Lithium concentrations in groundwater from sites in Dixie Valley, west-central Nevada. Highest lithium concentrations in groundwater sampled from western, northern, and southern areas of basin. 
This magnesium-lithium geothermometry method uses an empirical equation derived from the observed concentration of magnesium and lithium at different temperatures in basin-fill and geothermal basins (Kharaka and Mariner, 1989; Land and MacPherson, 1992). The equation used for this study was used to describe temperatures from geothermal basins worldwide (Kharaka and Mariner, 1989), was applied to basin-fill aquifers along the U.S. Gulf Coast, and is (results shown in fig. 17):

$$
\mathrm{T}=\frac{2200}{(5.47+\log [\sqrt{\mathrm{Mg}} / \mathrm{Li}]}-273.15
$$

where

$\mathrm{T} \quad$ is the calculated temperature in degrees Celsius;

$\mathrm{Mg}$ is the magnesium concentration of the fluid in milligrams per kilogram (mg/kg); and

$\mathrm{Li}$ is the concentration of lithium in the fluid in $\mathrm{mg} / \mathrm{kg}$.
In Dixie Valley, the magnesium-lithium geothermometer (equation 1) generally is in agreement (within 10 percent) with calculated reservoir temperatures using sodium-potassiumcalcium geothermometry for geothermal wells (table 11). However, the magnesium-lithium geothermometer shows reservoir temperatures averaging about 120 percent less than the equilibrium-based geothermometers using sodiumpotassium-calcium geothermometry for basin-fill wells (range is from 732 percent less to 82 percent more; table 11). This may be owing to: (1) non-equilibrium conditions in the basin-fill aquifer, (2) possible addition of magnesium to the basin from weathering of basalts and dolomite that could affect the empirical relation between magnesium and lithium, or (3) high concentrations of silica (greater than $50 \mathrm{mg} / \mathrm{L}$ ) in cold groundwater from dissolution of diatoms or tuff deposits. Additionally, evapotranspiration of the shallow groundwater and wind-blown evaporites from the playa and nearby Carson Sink could increase sodium and potassium concentrations so they are not in equilibrium with feldspar reactions. These factors might explain the differences in separate geothermometer-derived reservoir temperatures calculated for groundwater in the cold basin-fill aquifer.

Table 11. Estimated reservoir temperatures based on magnesium-lithium geothermometer compared to sodium-potassium-calcium geothermometer and measured field groundwater temperatures, Dixie Valley, west-central Nevada.

[Site No.: Locations of sites are shown in figure 17. Geothermal mixing: Zero percent mixed indicates no mixing with geothermal aquifer. A bbreviations: ${ }^{\circ} \mathrm{C}$, degrees Celsius; NA, sodium; K, potassium, Ca, calcium; n/a, not applicable; -, no data]

\begin{tabular}{|c|c|c|c|c|c|}
\hline \multirow[b]{2}{*}{ Site No. } & \multirow[b]{2}{*}{$\begin{array}{c}\text { Groundwater } \\
\text { temperature } \\
\left({ }^{\circ} \mathrm{C}\right)\end{array}$} & \multicolumn{3}{|c|}{ Geothermometer } & \multirow[b]{2}{*}{$\begin{array}{l}\text { Geothermal } \\
\text { mixing } \\
\text { (percent) }\end{array}$} \\
\hline & & $\begin{array}{l}\text { Magnesium- } \\
\text { lithium } \\
\left({ }^{\circ} \mathrm{C}\right)\end{array}$ & $\begin{array}{l}\text { Sodium-potassium- } \\
\text { calcium } \\
\left({ }^{\circ} \mathrm{C}\right)\end{array}$ & $\begin{array}{c}\text { Difference } \\
\text { (percent) }\end{array}$ & \\
\hline \multicolumn{6}{|c|}{ Basin-fill sites } \\
\hline 09 & 15.5 & 46.8 & 83.9 & -79 & 12.4 \\
\hline 12 & 28.2 & 34 & 66.6 & -96 & 2.3 \\
\hline 14 & 21.7 & 63.1 & 170 & -169 & 16.4 \\
\hline 15 & 34.4 & 66.7 & 172 & -158 & 12.8 \\
\hline 16 & 19 & 41.2 & 91 & -121 & 8.8 \\
\hline 17 & 15.2 & 47.2 & 174 & -269 & 12.7 \\
\hline 19 & 15.5 & 63.7 & 132 & -107 & 19.1 \\
\hline 20 & 15.5 & 46.4 & 85.6 & -84 & 12.3 \\
\hline 22 & 15.4 & 52 & 186 & -258 & 14.5 \\
\hline 23 & - & 8.8 & 65.41 & -643 & 0.0 \\
\hline 25 & 15.3 & 19.7 & 57.9 & -194 & 1.7 \\
\hline 26 & 16.7 & 3.7 & 30.8 & -732 & 0.0 \\
\hline 29 & 21.4 & 62.6 & 126 & -101 & 16.3 \\
\hline 30 & 15.8 & 20.4 & 97.5 & -378 & 1.8 \\
\hline 31 & 15.4 & 33.8 & 49.1 & -45 & 7.3 \\
\hline 32 & - & 36 & 57.7 & -60 & 0.0 \\
\hline
\end{tabular}


Table 11. Estimated reservoir temperatures based on magnesium-lithium geothermometer compared to sodium-potassium-calcium geothermometer and measured field groundwater temperatures, Dixie Valley, west-central Nevada.-Continued

[Site No.: Locations of sites are shown in figure 17. Geothermal mixing: Zero percent mixed indicates no mixing with geothermal aquifer. A bbreviations: ${ }^{\circ} \mathrm{C}$, degrees Celsius; NA, sodium; K, potassium, Ca, calcium; n/a, not applicable; -, no data]

\begin{tabular}{|c|c|c|c|c|c|}
\hline \multirow[b]{2}{*}{ Site No. } & \multirow[b]{2}{*}{$\begin{array}{c}\text { Groundwater } \\
\text { temperature } \\
\left({ }^{\circ} \mathrm{C}\right)\end{array}$} & \multicolumn{3}{|c|}{ Geothermometer } & \multirow[b]{2}{*}{$\begin{array}{c}\text { Geothermal } \\
\text { mixing } \\
\text { (percent) }\end{array}$} \\
\hline & & $\begin{array}{l}\text { Magnesium- } \\
\text { lithium } \\
\left({ }^{\circ} \mathrm{C}\right)\end{array}$ & $\begin{array}{l}\text { Sodium-potassium- } \\
\text { calcium } \\
\left({ }^{\circ} \mathrm{C}\right)\end{array}$ & $\begin{array}{c}\text { Difference } \\
\text { (percent) }\end{array}$ & \\
\hline \multicolumn{6}{|c|}{ Basin-fill sites-Continued } \\
\hline 34 & 16.2 & 46.6 & 61.9 & -33 & 12.1 \\
\hline 35 & 17.4 & 55.7 & 62.9 & -13 & 15.2 \\
\hline 36 & 15 & 37.8 & 60.0 & -59 & 9.0 \\
\hline 38 & 20 & 51.5 & 69.6 & -35 & 12.5 \\
\hline 41 & 19.4 & 67.7 & 63 & 7 & 19.2 \\
\hline 42 & 19.4 & 33.9 & 63 & -86 & 5.8 \\
\hline 43 & 19.9 & 40.4 & 69.5 & -72 & 8.1 \\
\hline 44 & 20.5 & 67.2 & 65.6 & 2 & 18.5 \\
\hline 50 & 18 & 47.8 & 64.6 & -35 & 11.8 \\
\hline 53 & - & 54.7 & 82.7 & -51 & 0.0 \\
\hline 55 & 41.4 & 42.3 & 72.1 & -70 & 0.4 \\
\hline 56 & 26.3 & 40.3 & 62.8 & -56 & 5.6 \\
\hline 60 & 22.2 & 19.4 & 29.1 & -50 & 0.0 \\
\hline 61 & - & 24.9 & 19.5 & 22 & 0.0 \\
\hline S3 & 13.8 & 6.24 & 21.8 & -249 & 0.0 \\
\hline S8 & 15.3 & 14.8 & 2.66 & 82 & 0.0 \\
\hline S11 & 6.9 & 52.2 & 208 & -298 & 18.0 \\
\hline $\mathrm{S} 13$ & 4.3 & 56.6 & 49.5 & 13 & 20.8 \\
\hline S16 & 8.7 & 26.6 & 19.5 & 27 & 7.1 \\
\hline S18 & 10.3 & 39.4 & 122 & -210 & 11.5 \\
\hline S20 & 22.4 & 21.2 & 74 & -249 & 0.0 \\
\hline $\mathrm{S} 22$ & 18.6 & 48.1 & 99.5 & -107 & 11.7 \\
\hline $\mathrm{S} 23$ & 29 & 108 & 66.5 & 38 & 31.3 \\
\hline $\mathrm{S} 25$ & 26 & 82.1 & 48.9 & 40 & 22.3 \\
\hline S28 & 58.5 & 123 & 123 & 0 & 25.6 \\
\hline S30 & 60.9 & 98.7 & 164 & -66 & 15.0 \\
\hline S32 & 21.8 & 58.2 & 96.6 & -66 & 14.4 \\
\hline S33 & 30.2 & 54.3 & 98.7 & -82 & 9.6 \\
\hline S39 & 44.8 & 42 & 72.8 & -73 & 0.0 \\
\hline S45 & 62.1 & 71.6 & 60.9 & 15 & 3.8 \\
\hline Average & 23 & 47 & 87 & -121 & 10 \\
\hline \multicolumn{6}{|c|}{ Selected geothermal wells ${ }^{1}$} \\
\hline G25 & 174 & 260 & 235 & 10 & $\mathrm{n} / \mathrm{a}$ \\
\hline G30 & 165 & 242 & 238 & 2 & $\mathrm{n} / \mathrm{a}$ \\
\hline G29 & 165 & 260 & 237 & 9 & $\mathrm{n} / \mathrm{a}$ \\
\hline G3 & - & 233 & 254 & -8 & $\mathrm{n} / \mathrm{a}$ \\
\hline G86 & 166 & 266 & 235 & 12 & $\mathrm{n} / \mathrm{a}$ \\
\hline G11 & - & 246 & 232 & 6 & $\mathrm{n} / \mathrm{a}$ \\
\hline G23 & 174 & 262 & 234 & 11 & $\mathrm{n} / \mathrm{a}$ \\
\hline G14 & - & 249 & 230 & 8 & $\mathrm{n} / \mathrm{a}$ \\
\hline Average & 169 & 252 & 237 & 6 & $\mathrm{n} / \mathrm{a}$ \\
\hline
\end{tabular}

${ }^{1}$ Calculated Na-K-Ca temperatures from Goff and others (2002). 


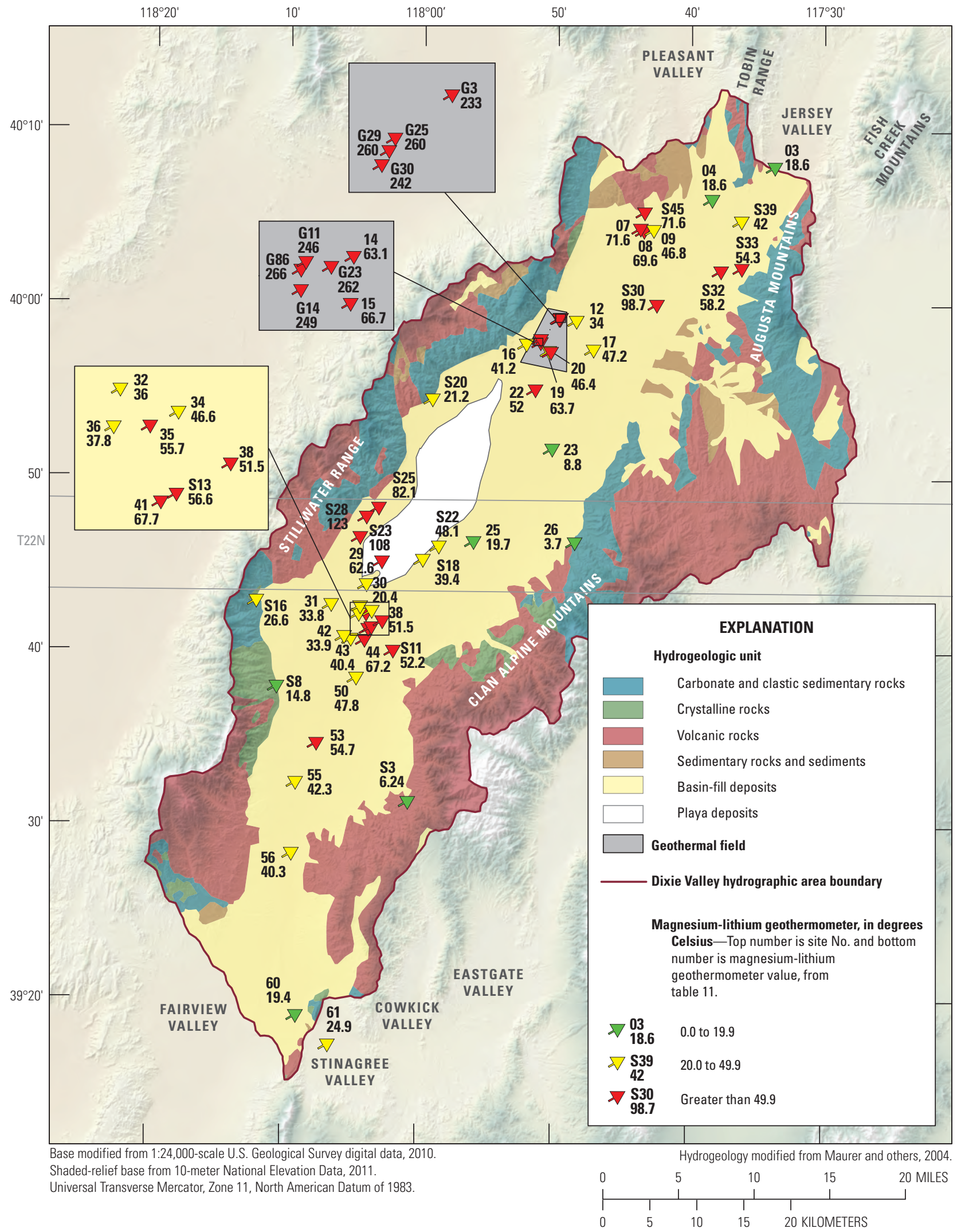

Figure 17. Locations of magnesium-lithium geothermometers and temperatures recorded in Dixie Valley, west-central Nevada. 
The use of the magnesium-lithium geothermometry represents a conservative estimate of basin-fill aquifer heating because temperatures calculated using this method are lower than temperature from all the other equilibrium-based geothermometers. Therefore, percentages of mixing between geothermal and cold basin-fill groundwater could be higher than estimated here.

Groundwater that initially may have had high magnesium concentrations from a cold-water source, or high lithium concentrations from geothermal water could show lower concentrations of these constituents because of water-rock interaction with the playa aquifer sediments rich in smectite clay. For example, a combination of low magnesium concentrations (less than $0.3 \mathrm{mg} / \mathrm{L}$ ) and low lithium concentrations (about $100 \mu \mathrm{g} / \mathrm{L}$ ) in groundwater collected in the shallow subsurface of the playa is uncharacteristic of evaporated, cold basin-fill water and (or) geothermally mixed water, and indicate that magnesium and lithium can be lost to clays without geothermal heating. Although playa water is warm (about $20^{\circ} \mathrm{C}$ ), temperatures are not high enough to lower magnesium solubility. Loss of magnesium and lithium from solution most likely is due to interactions with smectite clay minerals present in the playa sediments. X-ray diffraction analyses confirm the presence of high-purity smectite clays in the less-than-0.03 micron fraction (D. Webster, U.S. Geological Survey, written commun., 2012) that can readily sorb lithium at exchange sites (Williams and Hervig, 2002). Smectite clays also use magnesium in their crystal structure (Deer and others, 1966). Therefore, in areas where aquifer water interacts with smectite clay-rich playa sediments, the use of magnesium and lithium constituents to investigate geothermal mixing could produce erroneous results.

Given the complications of using the magnesium-lithium geothermometry for the samples in this study, the field measured groundwater temperatures ranged from as low as $3.7^{\circ} \mathrm{C}$ in a mountain front well (site 26) to more than $105^{\circ} \mathrm{C}$ in two springs near known geothermal areas (S23 and S28, table 11; fig. 17). Most basin-fill aquifer water sampled in this study seems to come from water that was heated above background mountain-front recharge temperatures (between 3 and $15^{\circ} \mathrm{C}$ ), indicating the influence of mixing with warm, possibly geothermally derived water.

Mixing of geothermal and cold basin-fill groundwater also was calculated by comparing the calculated magnesiumlithium geothermometry reservoir temperature to the field groundwater temperature of the well or spring when sampled (table 11). The difference in temperature divided by the average geothermal production well temperatures $\left(252^{\circ} \mathrm{C}\right.$, calculated by magnesium-lithium geothermometry in table 11) indicates that an average of about 10 percent mixing occurs between the geothermal and basin-fill aquifers, with a range of 0 percent mixing to more than 31 percent in some springs.

Confirmation of geothermal mixing with basin-fill groundwater comes from several lines of evidence: (1) high concentrations of geothermally derived trace elements such as lithium, silica, and boron; (2) water temperatures greater than mountain-front recharge temperatures; (3) results of geothermometry calculations using multiple methods; and (4) although not discussed here, augmentation of geothermal pressures by reinjecting cold basin-fill groundwater above the geothermal reservoir. This reinjection has reduced the chloride content of the geothermal production bores, indicating a connection between the overlying aquifer and the geothermal reservoir (Benoit and others, 2000).

There is no single method for estimating geothermal mixing that is considered ideal in a natural environment. Methods presented in this study, including groundwater temperature, geothermal and non-geothermal indicators (lithium, silica, and boron), and magnesium-lithium geothermometry, all have complicating factors. However, each method points to the same general conclusion that most basin-fill groundwater sampled throughout Dixie Valley during this study contains some fraction of water derived from a warmer source, indicating that groundwater could contain as much as 46 percent geothermal water, with the average mixing estimated at 10-12 percent-findings similar to previous findings by Bruton and others (1997). Samples collected from wells in the north, south, and west sides of the basin show greater mixing than those on the east side of the Dixie Valley.

\section{Summary}

Dixie Valley primarily is an undeveloped basin in westcentral Nevada, and the terminus of the Dixie Valley flow system, which includes Pleasant, Jersey, Fairview, Stingaree, Eastgate, and Cowkick Valleys. Churchill County, Nevada, is investigating additional water resources in Dixie Valley and has proposed to pump and transport groundwater from the fresh basin-fill aquifer. This study provides an improved understanding of groundwater resources in Dixie Valley by characterizing the hydrogeologic framework, the occurrence and movement of groundwater, the general chemical quality of the basin-fill aquifer, and the potential mixing between basin-fill and geothermal aquifers in Dixie Valley.

Rocks and sediments in Dixie Valley were grouped into six hydrogeologic units based on similar lithologies and hydraulic properties affecting groundwater flow: (1) the playa deposits, (2) basin-fill deposits, (3) carbonate and clastic sedimentary rocks, (4) crystalline rocks, (5) tertiary sedimentary rocks and sediments, and (6) volcanic rocks. Consolidated rock units include carbonate and clastic sedimentary rocks of Triassic-to Jurassic-age, crystalline rocks of Triassic-to-Tertiary age, sedimentary rocks and sediments of Tertiary age, and volcanic rocks of Tertiary age. Unconsolidated rock units include basin-fill and playa deposits of Quaternary age. 
The basin-fill hydrogeologic unit can be several orders of magnitude more transmissive than the surrounding and underlying consolidated rocks and playa deposits. The hydraulic properties of the basin-fill deposits were estimated from single- and multi-well aquifer tests and specificcapacity tests. Transmissivity estimated from aquifer tests done on flowing wells screened in basin-fill just south of the playa ranged from 400 to 1,400 feet squared per day $\left(\mathrm{ft}^{2} / \mathrm{d}\right)$ (average of $925 \mathrm{ft}^{2} / \mathrm{d}$ ). Estimates of transmissivity from three single-well aquifer tests done on southern Dixie Valley wells screened in basin-fill ranged from 700 to $6,000 \mathrm{ft}^{2} / \mathrm{d}$ (average of $3,100 \mathrm{ft}^{2} / \mathrm{d}$ ). Transmissivity estimated using specificcapacity data from 25 well sites throughout Dixie Valley and screened in basin-fill ranged from 30 to $45,500 \mathrm{ft}^{2} / \mathrm{d}$. Values estimated from wells north of Township 22N averaged 225 percent more than values from wells south of Township $22 \mathrm{~N}$. Although transmissivity estimates from aquifer tests generally are more accurate and reliable than estimates from specific capacity, the aquifer-test- and specific-capacityderived estimates from neighboring wells typically were similar (within the same order of magnitude).

A potentiometric surface map developed from current and historic depth-to-groundwater and land-surface elevation measurements was used to evaluate the occurrence and movement of groundwater in Dixie Valley. Groundwater generally flows from the mountain range uplands toward the central valley lowlands and eventually discharges near the playa edge. Potentiometric contours east and west of the playa indicate that groundwater is moving eastward from the Stillwater Range and westward from the Clan Alpine Mountains toward the playa. Similarly, groundwater flows from the southern and northern basin boundaries toward the Dixie Valley playa. North-south- and east-west-trending flow patterns support a previous hypothesis that the playa hydraulically separates groundwater north and south of Township 22N.

In addition to hydraulically separating groundwater flow between the northern and southern systems, groundwater in the Dixie Valley playa is chemically distinct from the freshwater basin-fill aquifer. Groundwater mixing between basin-fill and playa groundwater systems is likely physically impeded by transmissivity contrasts of about four orders of magnitude. Density contrasts between basin-fill and playa groundwater averaged 0.16 milligram per liter $(\mathrm{mg} / \mathrm{L})$, resulting in chemical flow barriers. Total dissolved solids concentrations in the playa groundwater were nearly 440 times greater than concentrations in the basin-fill aquifer. It should be noted that this finding is based on two wells screened in the playa deposits at depth of 10 feet or less. These large differences between physical and chemical characteristics suggest that groundwater interaction between the basin-fill and playa sediments was minimal during this study; however, some interaction likely occurs over longer time periods.
Groundwater levels in Dixie Valley have remained generally constant since the 1950s. Observed changes are mostly in areas of historical localized development as a result of withdrawals for irrigation, livestock, and domestic use, and from augmentation of geothermal reservoir pressure. Water levels north of the Dixie Valley playa have risen and declined over time (-15 to $5 \mathrm{ft}$ ), and likely correspond to changes in agricultural and geothermal pumping. South of the playa, where the basin-fill aquifer is semi-confined, water levels have increased by an average of 1.5-3 ft since the 1980s. Rising water levels likely are a result of the capping and sealing of local flowing wells and aquifer recovery from reduced agricultural pumping following U.S. Navy land acquisitions in the 1980s. Water-level data are sparse in southern Dixie Valley (south of latitude $39^{\circ} 35^{\prime} 0^{\prime \prime} \mathrm{N}$ ); however, one well showed a water-level decline of about $3.5 \mathrm{ft}$ from the late 1980s to the late 2000s, possibly from groundwater withdrawals for livestock watering.

Estimates of subsurface inflow to Dixie Valley from adjacent basins were calculated using a Darcian flux through the basin-fill aquifer. Annual subsurface inflow from Fairview and Jersey Valleys ranges from 700 to 1,300 acre-feet per year and from 1,800 to 2,300 acre-feet per year, respectively. Basin-fill deposits at the divide between Dixie and Stingaree Valleys are shallow and dry, indicating that the water table is in the deeper, less transmissive consolidated rock. Therefore, subsurface inflow was not estimated because transmissivity and water-level data within the volcanic rock unit were largely unknown. Although groundwater likely flows from Pleasant Valley to Dixie Valley, the divide is composed of carbonate rocks; therefore, subsurface flow was not estimated in this study owing to a lack of hydraulic information within the rock unit.

The chemical characteristics of groundwater in Dixie Valley were evaluated using data collected from wells and springs. Differences in magnesium concentrations and co-dominant anion composition in groundwater samples collected from the north and south valley areas indicate that groundwater north and south of Township 22N differs chemically. Groundwater in northern Dixie Valley generally is a sodium bicarbonate-chloride type, whereas groundwater south of Township $22 \mathrm{~N}$ is a sodium bicarbonate-sulfate type. All major ions, including dissolved solids, differed significantly between samples collected north and south of the playa.

Some constituents in groundwater samples collected from Dixie Valley exceeded established drinking-water quality criteria. Primary drinking water standards were exceeded for arsenic $(0.01 \mathrm{mg} / \mathrm{L} ; 41$ of 64 sites $)$ and fluoride $(4 \mathrm{mg} / \mathrm{L}$; 17 of 45 sites), and secondary drinking water standards were exceeded for total dissolved solids ( $500 \mathrm{mg} / \mathrm{L}$; 35 of 65 sites) and manganese $(0.05 \mathrm{mg} / \mathrm{L} ; 15$ of 62 sites). Boron and tungsten do not have national drinking water standards but 
can cause adverse health effects. Although a drinking water criterion was unavailable for boron, the provisional boron guideline of $0.5 \mathrm{mg} / \mathrm{L}$ was exceeded in 33 of 60 sites; no guideline currently exists for tungsten.

Several methods of chemical comparisons between basin-fill and geothermal aquifer water indicate that most basin-fill groundwater sampled generally contains 10-12 percent geothermal water-a range similar to that of previous findings. Stable isotopes of oxygen-18 and deuterium, and geothermal indicators such as high temperature, lithium, boron, chloride, and silica indicate that mixing occurs in many wells that tap the basin-fill aquifer, particularly on the north, south, and west sides of the basin. A horizontal positive shift in oxygen-18 signatures of cool and warm groundwater away from the local meteoric water line and toward geothermal groundwater highlights potential mixing between basin-fill and geothermal aquifer waters. The mixing of lithium end-members indicates that many concentrations of lithium in cold groundwater are less than 51 micrograms per liter, and suggests only 1 or 2 percent mixing with geothermal water. Twenty-seven of the 51 cold samples analyzed (near or north of the geothermal field) show as much as 46 percent mixing with geothermal water. Magnesium-lithium geothermometers indicate that most basinfill aquifer water sampled for this study apparently originates from water that was heated above background mountain-block recharge temperatures (between 3 and 15 degrees Celsius), indicating the influence of mixing with warm water, likely derived from geothermal sources.

\section{Acknowledgments}

The authors gratefully acknowledge Mahannah and Associates, LLC, and Interflow Hydrology, Inc., for fieldwork and data collection; the Bureau of Reclamation and Justin Huntington for scientific insight; and Subhrendu Gangopadhyay (Bureau of Reclamation) and Thomas Marston (U.S. Geological Survey, Utah Water Science Center) for helpful review comments. Sincere appreciation is extended to Gary Cottle (U.S. Naval Air Station), Paul Plouviez (Bench Creek Ranch), and Rob Lincoln (local resident) for their local knowledge and cooperation throughout this study. Many USGS colleagues helped make this project successful and rewarding, including Toby L. Welborn, James L. Wood, Robert N. Pennington, John-Eric Schroder, Lindsay Burt, and Carl E. Thodal for help with well inventory, water-quality sampling, well drilling, and truly inspiring field ingenuity; David W. Smith and Keith J. Halford for aquifer testing, data entry, and constructive criticism; Suzanne L. Crowley for water-quality sampling and diligent data entry; and Sonya L. Vasquez for data entry and problem solving. The Bureau of Reclamation supported this work under Interagency Agreement R10PG80297.

\section{References Cited}

Abbott, R.E., Louie, J.N., Caskey, S.J., and Pullammanappallil, S., 2001, Geophysical confirmation of low-angle normal slip on the historically active Dixie Valley Fault, Nevada: Journal of Geophysical Research, v. 106, no. B3, p 4169-4181.

Agency for Toxic Substances and Disease Registry, 2005, Toxicological profile for tungsten: U.S. Department of Health and Human Services Public Health Service, Agency for Toxic Substances and Disease Registry, 163 p., accessed January 24, 2014, at http://www.atsdr.cdc.gov/toxprofiles/ tp186.pdf.

Association of State and Territorial Solid Waste Management Officials, 2008, Tungsten issues paper: Washington, D.C., Association of State and Territorial Solid Waste Management Officials (ASTSWMO), 9 p., accessed May 24, 2012, at http://www.astswmo.org/Files/Policies_ and_Publications/Federal_Facilities/TUNGSTEN_ FINAL_120208.pdf.

Barlow, P.M., 2003, Groundwater in freshwater-saltwater environments of the Atlantic coast: U.S. Geological Survey Circular 1262, 113 p., http://pubs.usgs.gov/circ/2003/ circ1262/.

Barton, C.C., Hickman, S., Morin, R., Zoback, M.D., Finkbeiner, T., Sass, J., and Benoit, D., 1997, Fracture permeability and its relationship to in-situ stress in the Dixie Valley, Nevada, geothermal reservoir: Proceedings of the Twenty-Second Workshop on Geothermal Reservoir Engineering, Stanford University, Stanford California, January 27-29, 1997, p. 147-152.

Benoit, D., Johnson, S., and Kumataka, M., 2000, Development of an injection augmentation program at the Dixie Valley, Nevada geothermal field: Proceedings of the World Geothermal Congress, Kyushu-Tohoku, Japan, May 28-June 10, 2000, p. 819-824.

Benoit, D., 2011, The geothermal systems in Dixie Valley: Prepared for Churchill County, Nevada, by private consultant, 42 p., accessed June 6, 2014, at http://www. churchillcounty.org/DocumentCenter/View/5354.

Blackwell, D.D., Smith, R.P., and Richards, M.C., 2007, Exploration and development at Dixie Valley, Nevada-Summary of DOE studies: Proceedings of the Thirty-Second Workshop on Geothermal Reservoir Engineering, Stanford University, Stanford, California, January 22-24, 2007. 
Blackwell, D.D., Wisian, K.W., Benoit, D., and Gollan, B., 1999, Structure of the Dixie Valley geothermal system, a "typical” basin and range geothermal system, from thermal and gravity data: Geothermal Resources Council Transaction, v. 23, p. 525-531.

Blackwell, D.D., Wisian, K.W., Richards, M.C., Leidig, M., Smith, R., and McKenna, J., 2003, Geothermal resource analysis and structure of basin and range systems, especially Dixie Valley geothermal field, Nevada: Dallas, Tex., Southern Methodist University Department of Geological Sciences, 65 p.

Bouwer, Herman, and Rice, R.C., 1976, A slug test for determining hydraulic conductivity of unconfined aquifers with completely or partially penetrating wells: Water Resources Research, v. 12, no. 3, p. 423-428.

Boyle, R.W., and Jonasson, I. R., 1973, The geochemistry of arsenic and its use as an indicator element in geochemical prospecting: Journal of Geochemical Exploration, v. 2, no. 3, p. 251-296.

Bradley, J.V., 1968, Distribution-free statistical tests: Englewood Cliffs, New Jersey, Prentice-Hall, 388p.

Bruton, C.J., Counce, D., Bergfeld, D., Goff, F., Johnson, S.D., Moore, J.N., and Nimz, G., 1997, Preliminary investigation of scale formation and fluid chemistry at the Dixie Valley geothermal field, Nevada: Geothermal Resources Council Transactions annual meeting, October 12-15, 1997, 8 p.

Caine, J.S., Bruhn, R.L., and Forster, C.B., 2010, Internal structure, fault rocks, and inferences regarding deformation, fluid flow, and mineralization in the seismogenic Stillwater normal faults, Dixie Valley, Nevada: Journal of Structural Geology, v. 32, p. 1576-1589.

Campana, M., Mihevc, T., Jacobson, R., and Lyles, B., 1986, Hydrogeologic investigation and monitoring plan-Dixie Valley geothermal project: Desert Research Institute, Water Resources Center report, 51 p.

Cardinalli, J.L., Roach, L.M., Rush, F.E., and Vasey, B.J., 1968, State of Nevada hydrographic areas, in Rush, F.E., Index of hydrographic areas of Nevada: Nevada Division of Water Resources Information Report, 633 p.

Clark, I., and Fritz, P., 1997, Environmental isotopes in hydrogeology: Boca Raton, Fla., Lewis Publishers, 328 p.

Cohen, P., and Everett, D.E., 1963, A brief appraisal of the ground-water hydrology of the Dixie-Fairview Valley area, Nevada: Nevada Department of Conservation and Natural Resources, Ground-Water Resources-Reconnaissance Series Report 23, 40 p.
Cooper, H.H., and Jacob, C.E., 1946, A generalized graphical method for evaluating formation constants and summarizing well field history: American Geophysical Union Transactions, v. 27, p. 526-534.

D’Agnese, F.A., Faunt, C.C., Turner, A.K., and Hill, M.C., 1997, Hydrogeologic evaluation and numerical simulation of the Death Valley regional ground-water flow system, Nevada and California: U.S. Geological Survey WaterResources Investigations Report 96-4300, 124 p., http:// pubs.er.usgs.gov/publication/wri964300.

Davis, J.C., and DeWiest, R.J.M., 1966, Hydrogeology: New York, John Wiley \& Sons, Inc., 463 p.

Deer, W.A., Howie, R.A., and Zussman, J., 1966, An introduction to the rock-forming minerals: London, Longman Group Limited, 528 p.

Drever, J.I., 1982, The geochemistry of natural waters: Englewood Cliffs, N.J., Prentice-Hall, 388 p.

Duffy, C.J., and Al-Hassan, S., 1988, Groundwater circulation in a closed desert basin-Topographic scaling and climatic forcing: Water Resources Research, v. 24, no. 10, p. 1675-1688.

Eaton, F.M., 1935, Boron in soils and irrigation waters and its effect on plants: U.S. Department of Agriculture Technical Bulletin No. 448, 137 p.

Edmunds, W.M., and Smedley, P.L., 2013, Fluoride in natural waters, chap. 13 of Selinus, Olle, ed., Essentials of medical geology: Springer Netherlands, p. 311-336.

Ellis, A.J., and Mahon, W.A.J., 1977, Geochemistry and geothermal systems: New York, Academic Press, 392 p.

Foxall, B., and Vasco, D., 2003, Inversion of synthetic aperture radar interferograms for sources of productionrelated subsidence at the Dixie Valley geothermal field: Proceedings of the Twenty-Eighth Workshop on Geothermal Reservoir Engineering, Stanford University, Stanford, California, January 27-29, 1997, p. 181-187.

Garcia, C.A., Huntington, J.M., Buto, S.G., Moreo, M.T., Smith, J.L., and Andraski, B.J., 2014, Groundwater discharge by evapotranspiration, Dixie Valley, west-central Nevada, March 2009-September 2011: U.S. Geological Survey Professional Paper 1805, 96 p.

Garside, L., 1994, Nevada low-temperature geothermal resource assessment: Nevada Bureau of Mines and Geology, Open-File Report 94-2, accessed January 24, 2014, at http:// www.nbmg.unr.edu/geothermal/geochemdata/ofr94_2/ ofr94-2.htm. 
Geothermal Resources Council, 2014, GRC Geothermal Library: Geothermal Resources Council Web site, accessed February 7, 2014, at https://www.geothermal-library.org/.

Giggenbach, W.F., 1992, Chemical techniques in geothermal exploration, in D-Amore, F., ed., UNITAR/UNDP Guidebook-Applications of geochemistry in geothermal reservoir development: UNITAR/UNDP Centre on Small Energy Resources, p. 119-145.

Goff. F., Bergfeld, D., Janik, C.J., Counce, D., and Murrell, M., 2002, Geochemical data on waters, gases, scales, and rocks from the Dixie Valley Region, Nevada (1996-1999): Los Alamos National Laboratory, Technical Report LA-13972-MS, 71 p.

Grauch, V.J.S., 2002, High-resolution aeromagnetic survey to image shallow faults, Dixie Valley geothermal field, Nevada: U. S. Geological Survey Open-File Report 2002-384, 13 p., http://pubs.usgs.gov/of/2002/ofr-02-0384/.

Great Basin Center for Geothermal Energy, 2004, GIS Quaternary Fault Western U.S. dataset, (modified from U.S. Geological Survey Open-File Report 2003-417 by the Great Basin Center for Geothermal Energy): Reno, University of Nevada Web site, accessed November 3, 2009, at ftp://ftp. nbmg.unr.edu/pub/geothermal/03_Geology_Data.

Great Basin Center for Geothermal Energy, 2009, University of Nevada, Reno Great Basin Groundwater Geochemical Database, accessed July 31, 2009, at http://www.nbmg.unr. edu/Geothermal/GeochemDatabase.html.

Gunnlaugsson, E., 2008, Importance of chemistry in geothermal exploration and utilization: Presented at Workshop for Decision Makers on Direct Heating Use of Geothermal Resources in Asia, (organized by United Nations University-Geothermal Training Programme, TBLRREM, and TBGMED), Tianjin, China, May 11-18, 2008, 16 p., accessed January 26, 2012, at http://www.os.is/ gogn/unu-gtp-sc/UNU-GTP-SC-06-15.pdf.

Halford, K.J., and Kuniansky, E.L., 2002, Documentation of spreadsheets for analysis of aquifer-test and slug-test data: U.S. Geological Survey Open-File Report 2002-197, 51 p., http://pubs.usgs.gov/of/2002/ofr02197/.

Halford, K.J., Weight, W.D., and Schreiber, R.P., 2006, Interpretation of transmissivity estimates from singlewell pumping aquifer tests: Groundwater, v. 44, no. 3, p. $467-471$.

Harrill, J.R., and Hines, L.B., 1995, Estimated natural groundwater recharge, discharge, and budget for the Dixie Valley area, west-central Nevada: U.S. Geological Survey WaterResources Investigations Report 95-4052, 12 p., http://pubs. er.usgs.gov/publication/wri954052.
Harrill, J.R., and Prudic, D.E., 1998, Aquifer systems in the Great Basin region of Nevada, Utah, and adjacent statesSummary report: U.S. Geological Survey Professional Paper 1409-A, 66 p., http://pubs.er.usgs.gov/publication/ pp1409A.

Hounslow, A.W., 1995, Water quality data-Analysis and interpretation: Boca Raton, Fla., Lewis Publishers, 397 p.

Huntington, J.L., and Niswonger, R.G., 2012, Role of surface-water and groundwater interactions on projected summertime streamflow in snow dominated regions-An integrated modeling approach: Water Resources Research, v. 48, W11524, 20 p.

Interflow Hydrology, Inc., and Mahannah and Associates, LLC, 2012a, Dixie Valley spring reconnaissance and sampling report: Prepared for Churchill County, Nevada, by Interflow Hydrology, Inc., and Mahannah and Associates, 55 p., accessed March 13, 2014, at http://www. interflowhydro.com/pdf/Dixie-Valley-Spring-Report.pdf.

Interflow Hydrology, Inc., and Mahannah and Associates, LLC, 2012b, Summary of aquifer tests and analysis, Dixie Valley: Prepared for Churchill County, Nevada, by Interflow Hydrology, Inc., and Mahannah and Associates, LLC, 26 p., accessed June 9, 2014, at http://interflowhydro.com/pdf/ Aquifer_Testing_Dixie_Valley_Final_11272012a.pdf.

Interflow Hydrology, Inc., and Mahannah and Associates, LLC, 2013, Monitoring of stream flows and playa run-on in Dixie Valley for water years 2009, 2010, and 2011: Prepared for Churchill County, Nevada, by Interflow Hydrology, Inc., and Mahannah and Associates, LLC, 46 p., accessed March 13, 2014, at http://www.interflowhydro. com/pdf/Dixie_Valley_Streamflow_Report.pdf.

Izbicki, J.A., 2004, Source and movement of ground water in the western part of the Mojave Desert, southern California, USA: U.S. Geological Survey Water-Resources Investigation Report 2003-4313, 28 p., http://pubs.usgs.gov/ wri/wrir034313/.

Jacob, C.E., and Lohman, S.W., 1952, Nonsteady flow to a well of constant drawdown in an extensive aquifer: Transactions of the American Geophysical Union, v. 33, no. 4, p. 559-569.

Johnson, M.G., 1977, Geology and mineral deposits of Pershing County, Nevada: Nevada Bureau of Mines and Geology Bulletin 89, 115 p.

Kenny, J.F., Barber, N.L., Huston, S.S., Kinsey, K.S., Lovelace, J.K., and Maupin, M.A., 2009, Estimated use of water in the United States in 2005: U.S. Geological Survey Circular 1344, 52 p., http://pubs.usgs.gov/circ/1344/. 
Kharaka, Y.K., and Mariner, R.H., 1989, Chemical geothermometers and their application to formation waters from sedimentary basins, in Naeser, D., and Mc Culloh, T.H., eds., Thermal history of sedimentary basins: New York. Springer-Verlag, 319 p.

Kormos, P.R., 2005, Accounting for time and space variations of $\delta^{18} \mathrm{O}$ in a snowmelt isotopic hydrograph separation in the Boise Front: Boise, Idaho, Boise State University, M.S. Thesis, $47 \mathrm{p}$.

Lahontan GeoScience, Inc., 2004, Dixie Valley groundwater quality report: Reno, Nev., Lahontan GeoScience, Inc. report, project number 03130, $58 \mathrm{p}$.

Land, L.S., and MacPherson, G.L., 1992, Geothermometry from brine analysis: lessons from the Gulf Coast, U.S.A.: Applied Geochemistry, v. 7, p. 333-340.

Lohman, S.W., 1979, Ground-water hydraulics: U.S. Geological Survey Professional Paper 708, 70 p., http:// pubs.er.usgs.gov/publication/pp708.

Lohman, S.W., and others, 1972, Definitions of selected ground-water terms-Revisions and conceptual refinements: U.S. Geological Survey Water-Supply Paper 1988, 21 p., http://pubs.usgs.gov/wsp/wsp_1988/.

Ludington, S., Cox, D.P., Leonard, K.W., and Moring, B.C., 1996, Cenozoic volcanic geology of Nevada, chap. 5 of Singer, D.A., ed., An analysis of Nevada's metal-bearing mineral resources: Nevada Bureau of Mines and Geology Open-File Report 96-2, 10 p., accessed January 29, 2014, at http://www.nbmg.unr.edu/dox/ofr962/.

Mankhemthong, N., 2008, Structure of the inter-basin transition zone between Dixie Valley and Fairview Valley, Nevada, USA: Reno, University of Nevada, M.S. Thesis, $120 \mathrm{p}$.

Mankhemthong, N., Oppliger, G.L., and Aslett, Z., 2008, Structural localization of two low temperature geothermal systems within the gravity defined linkage between Dixie Valley and Fairview Valley, Nevada, USA: Geothermal Resources Council Transactions, v. 32, p. 219-295.

Maurer, D.K., 2011, Geologic framework and hydrogeology of the Middle Carson River Basin, Eagle, Dayton, and Churchill Valleys, west-central Nevada: U.S. Geological Survey Scientific Investigations Report 2011-5055, 62 p., http://pubs.usgs.gov/sir/2011/5055/.

Maurer, D.K., Lopes, T.J., Medina, R.L., and Smith, J.L., 2004, Hydrogeology and hydrologic landscape regions of Nevada: U.S. Geological Survey Scientific Investigations Report 2004-5131, 36 p., http://pubs.usgs.gov/ sir/2004/5131/.
McKenna, J.R., and Blackwell, D.D., 2004, Numerical modeling of transient Basin and Range extensional geothermal systems: Geothermics, v. 33, p. 657-662

McMahon, P.B., and Chapelle, F.H., 2008, Redox processes and water quality of selected principal aquifer systems: Groundwater, v. 46, no. 2, p. 259-271.

Misrach, Richard, 1990, Bravo 20-The bombing the American West: Baltimore, Md., John Hopkins University Press, $152 \mathrm{p}$.

Morrison, R.B., 1964, Lake Lahontan-Geology of southern Carson Desert, Nevada: U.S. Geological Survey Professional Paper 401, 156 p.

Nevada Administrative Code 445A.455, Revised March 2012, Chapter 445A-Water controls, secondary standardsGeneral requirements: Nevada Administrative Code accessed January 14, 2014, at http://www.leg.state.nv.us/ nac/nac-445a.html.

Nevada Division of Water Resources, 2012, Underground active basin summaries: Nevada Division of Water Resources database, accessed July 5, 2012, at http://water. nv.gov/data/underground/.

National Institute for Occupational Safety and Health, 2005, National Institute for Occupational Safety and Health (NIOSH) Pocket Guide to Chemical Hazards-Tungsten: Department of Health and Human Services NIOSH Publication No. 2005-149, 454 p., accessed May 24, 2012, at: http://www.cdc.gov/niosh/docs/2005-149/pdfs/2005-149. pdf.

Nimz, G., Janik, C., Goff, F., Dunlap, C., Huebner, M., Counce, D., and Johnson, S., 1999, Regional hydrology of the Dixie Valley Geothermal Field, NevadaPreliminary interpretations of chemical and isotopic data: Eighth International Conference on Accelerator Mass Spectrometry, Vienna, Austria, September 6-10, 1999, 9 p.

Page, B.M., 1965, Preliminary geologic map of a part of the Stillwater Range, Churchill County, Nevada: Nevada Bureau of Mines geologic map 28, 1 sheet, accessed January 29, 2014, at http://www.nbmg.unr.edu/dox/m28. pdf.

Plume, R.W., 1996, Hydrogeologic framework of the Great Basin region of Nevada, Utah, and adjacent states: U.S. Geological Survey Professional Paper 1409-B, 64 p, http:// pubs.er.usgs.gov/publication/pp1409B.

Plume, R.W., 2009, Hydrogeologic framework and occurrence and movement of ground water in the Upper Humboldt River Basin, Northeastern Nevada, U.S. Geological Survey Scientific Investigations Report 2009-5014, 23 p., http:// pubs.usgs.gov/sir/2009/5014/. 
PRISM Climate Group, 2004, Parameter-elevation

Regressions on Independent Slopes Model (PRISM) climate data for October 2009 to September 2011: Corvallis, Oregon State University, PRISM database, accessed January 29, 2014, at http://prism.oregonstate.edu.

Rademacher, L.K., Clark, J.F., and Hudson, G.B., 2002, Temporal changes in stable isotope composition of spring waters-Implications of recent changes in climate and atmospheric circulation: Geology, v. 30, no. 2, p. 139-142.

Reheis, M., 1999, Extent of Pleistocene lakes in the western Great Basin: U.S. Geological Survey Miscellaneous Field Studies Map MF-2323, 1 map sheet, accessed January 29, 2014, at http://pubs.usgs.gov/mf/1999/mf-2323/.

Robinson, T.W., 1958, Phreatophytes: U.S. Geological Survey Water Supply Paper 1423, 84 p., http://pubs.er.usgs.gov/ publication/wsp1423.

Romney, C.F., 1957, Seismic waves from the Dixie ValleyFairview Peak earthquakes: Seismology Society of America Bulletin, v. 47, no. 4, p. 301-319.

Rush, F.E., 1968, Index of hydrographic areas: Nevada Division of Water Resources Information Report 6, 38 p.

Schaefer, D.H., 1983, Gravity survey of Dixie Valley, westcentral Nevada: U.S. Geological Survey Open-File Report 82-111, 22 p., http://pubs.er.usgs.gov/publication/ofr82111.

Schaefer, D.H., Thiros, S.A., and Rosen, M.R., 2005, Groundwater quality in the carbonate-rock aquifer of the Great Basin, Nevada and Utah, 2003: U. S. Geological Survey Scientific Investigations Report 2005-5232, 32 p., http:// pubs.usgs.gov/sir/2005/5232/.

Seiler, R.L., Stollenwerk, K.G., and Garbarino, J.R., 2005, Factors controlling tungsten concentrations in ground water, Carson Desert, Nevada, Applied Geochemistry, v. 20, p. 423-441.

Smith, R.P., Wisian, K.W., and Blackwell, D.D., 2001, Geologic and geophysical evidence for intra-basin and footwall faulting at Dixie Valley, Nevada: Geothermal Resources Council Transactions, v. 25, p. 323-326.

Soil Survey Staff, 2012, Web soil survey: U.S. Department of Agriculture, Natural Resources Conservation Service database, accessed April 9, 2012, at http://websoilsurvey. nrcs.usda.gov/.

Stamates, M., 2001, Evaluation of the injection effects on the Dixie Valley, Nevada geothermal reservoir system through the use of geochemical data: Reno, University of Nevada, M.S. Thesis, $199 \mathrm{p}$.

Stewart, J.H., 1980, Geology of Nevada, a discussion to accompany the geologic map of Nevada: Nevada Bureau of Mines and Geology Special Publication 4, 136 p.
Stewart, J.H., and Carlson, J.E., 1978, Geologic map of Nevada: U.S. Geological Survey Map, 1 map sheet, scale 1:500,000.

Thompson, G.A., Meister, L.J., Herring, A.T., Smith, T.E., Burke, D.B., Kovach, R.L., Burford, R.O., Salehi, I.A., and Wood, M.D., 1967, Geophysical study of basin-range structure Dixie Valley region, Nevada: Stanford, California, Stanford University Final Scientific Report AFCRL-66-848.

Toth, J.A., 1962, A theory of groundwater motion in small drainage basins in central Alberta, Canada: Journal of Geophysical Research, v. 67, no. 11, p. 4375-4387.

U.S. Census Bureau, 2011, State and county quick facts, U.S. Census Bureau database, accessed August 26, 2011, at http://quickfacts.census.gov/qfd/states/32000.html.

U.S. Environmental Protection Agency, 1992, Secondary drinking water regulations-Guidance for nuisance chemicals: U.S. Environmental Protection Agency report EPA 810-K-92-001.

U.S. Environmental Protection Agency, 2008, Drinking water health advisory for boron: U.S. Environmental Protection Agency, document 822-R-08-013, 53 p., accessed March 20, 2012, at http://www.epa.gov/safewater/ccl/pdfs/ reg_determine2/healthadvisory_ccl2-reg2_boron.pdf.

U.S. Environmental Protection Agency, 2009, National primary drinking water regulations: U.S. Environmental Protection Agency, document EPA 816-F-09-0004, 6 p., accessed February 16, 2012, at http://water.epa.gov/drink/ contaminants/upload/mcl-2.pdf.

U.S. Environmental Protection Agency, 2010, Emerging contaminant-tungsten: U.S. Environmental Protection Agency fact sheet EPA 505-F-10-004, 4 p.

U.S. Geological Survey, 2006, Collection of water samples (ver. 2.0): U.S. Geological Survey Techniques of WaterResources Investigations, book 9, chap. A4, accessed September 9, 2009, at http://pubs.water.usgs.gov/twri9A4/.

U.S. Geological Survey, 2010, Aquifer tests: Carson City, Nev., U.S. Geological Survey database, accessed March 30, 2013, at http://nevada.usgs.gov/water/aquifertests/index. htm.

U.S. Geological Survey, 2014, National Water Information System data availale on the World Wide Web (USGS Water Data for the Nation), accessed August 5, 2014, at http:// waterdata.usgs.gov/nwis/.

U.S. Geological Survey, and Pearson, deRidder, and Johnson, Inc., 2002, A helicopter borne magnetic survey over Dixie Valley geothermal field, Nevada—A web site for distribution of data: U.S. Geological Survey Open-File Report 2002-374, 36 p., http://pubs.usgs.gov/of/2002/ofr02-0374/. 
Vanderburg, W.O., 1940, Reconnaissance of mining districts in Churchill County, Nevada: U.S. Bureau of Mines Information Circular 7093, 18 p.

Wilde, F.D., ed., 2004, Cleaning of equipment for water sampling (ver. 2.0): U.S. Geological Survey Techniques of Water-Resources Investigations, book 9, chap. A3, accessed October 22, 2009, at http://pubs.water.usgs.gov/twri9A3/.

Willden, R., and Speed, R.C., 1974, Geology and mineral deposits of Churchill County, Nevada: Nevada Bureau of Mines and Geology Bulletin 83, 92p.

Williams, L.B., and Hervig, R.L., 2002, Exploring intracrystalline B-isotope variations in mixed-layer illitesmectite: American Mineralogist Journal, v. 87, p. 1564-1570.

Wilt, M.J., and Goldstein, N.E., 1983, Electromagnetic sounds over a geothermal reservoir in Dixie Valley, Nevada: Lawrence Berkeley Laboratory report LBL-15526, 69 p.
Wisian, K.W., and Blackwell, D.D., 2004, Numerical modeling of basin and range geothermal systems: Geothermics, v. 33, no. 6, p. 713-741.

World Health Organization, 2003, Boron in drinking-water: Geneva, Switzerland, World Health Organization, accessed May 23, 2012, at http://whqlibdoc.who.int/hq/2009/WHO_ HSE_WSH_09.01_2_eng.pdf.

Zehner, R.E., Coolbaugh, M.F., and Shevenell, Lisa, 2006, Regional groundwater geochemical trends in the Great Basin-Implications for geothermal exploration: Geothermal Resources Council Transactions, v. 30, p. 117-124, accessed November 8, 2012, at http://pubs. geothermal-library.org/lib/grc/1025018.pdf.

Zones, C.P., 1957, Changes in hydrologic conditions in the Dixie Valley and Fairview Valley areas, Nevada, after the earthquake of December 16, 1954: Seismology Society of America Bulletin, v. 47, no. 4, p. 387-396. 


\section{Appendix A. Stable Isotopic Data for Bulk Precipitation Sites Within Dixie Valley Study Area, May 2009-November 2011}

Appendix A is a Microsoft ${ }^{\odot}$ Excel file and can be downloaded at http://pubs.usgs.gov/sir/2014/5152. 


\section{Appendix B. Determination of Lithium Using Inductively Coupled Plasma-Optical Emission Spectometry}

Prior to 2003, the U.S. Geological Survey National Water Quality Laboratory measured dissolved and whole-water recoverable lithium using radial-view Inductively Coupled Plasma-Optical Emission Spectrometry (ICP-OES). With the implementation of updated instrumentation, lithium subsequently has been measured using axial-view ICP-OES. Initial prove-out studies indicated that there was no significant difference between results obtained using the axial and radial views for samples with a wide range of dissolved-solids concentrations. Recently (2013), some analyses of samples from the Branch of Quality Systems Inorganic Blind Sample Program have shown a positive bias in lithium results. Such bias can occur as a result of ionization interferences associated with samples with relatively high concentrations of alkali (that is, sodium and potassium) and (or) alkali earth elements (that is, calcium and magnesium). This ionization interference is reduced substantially when using the radial view because of the shorter path length of the light emission measured.

The shorter path length in the radial view affects the method detection limit. The reporting limits for lithium in dissolved and whole-water samples analyzed using the axial view are 0.05 and 0.04 micrograms per liter $(\mu \mathrm{g} / \mathrm{L})$, respectively, whereas the corresponding reporting limits for lithium using the radial view are estimated at $0.1 \mu \mathrm{g} / \mathrm{L}$.

A procedure for correcting axial-view lithium concentrations for bias associated with ionization interference was established by simulating the axial and radial lithium results relative to alkali and alkali earth concentrations for more than 100 dissolved and whole-water samples. The lithium concentrations in the model samples ranged from 0.5 to more than $6,000 \mu \mathrm{g} / \mathrm{L}$, whereas concentrations of concomitant alkali and alkali earth elements ranged from 0.5 to more than 19,000 $\mathrm{mg} / \mathrm{L}$. Linear least squares regression of the ratio of radial-lithium concentration to axial-lithium concentration as a function of log10 (calcium $[\mathrm{Ca}]+$ magnesium $[\mathrm{Mg}]+$ sodium $[\mathrm{Na}]+$ potassium $[\mathrm{K}]$ concentration) resulted in an equation that can be used to convert axial-lithium results to radial-lithium results if calcium, magnesium, sodium and potassium concentrations are known. The regression equation is:

$$
\begin{gathered}
(\text { axial }-\mathrm{Li} / \text { radial }-\mathrm{Li}) \text { ratio }=0.3062 \times \\
\log 10(\mathrm{Ca}+\mathrm{Mg}+\mathrm{Na}+\mathrm{K}, \text { in } \mathrm{mg} / \mathrm{L})+0.7748
\end{gathered}
$$

After determining the (axial-Li/radial-Li) ratio for a particular sample, the radial-Li concentration is calculated by dividing the previously measured axial-Li concentration by the (axial-Li/radial-Li) ratio.

The accuracy of the correction equation for more than 900 dissolved and whole-water samples is shown in figure B1. Results for lithium from measured radial-ICPOES are compared to calculated radial-lithium results from equation B1. For the dissolved samples tested, there is a positive bias of about 6 percent between the measured and calculated radial-lithium concentrations; for whole-water samples, there is a negative bias of about 6 percent. This bias signifies the overall accuracy of the correction for the range of lithium, alkali, and alkali earth concentrations in the samples used in the evaluation. Perfect correlation between the measured and calculated results would give a regression line with a slope equal to 1.0 . 

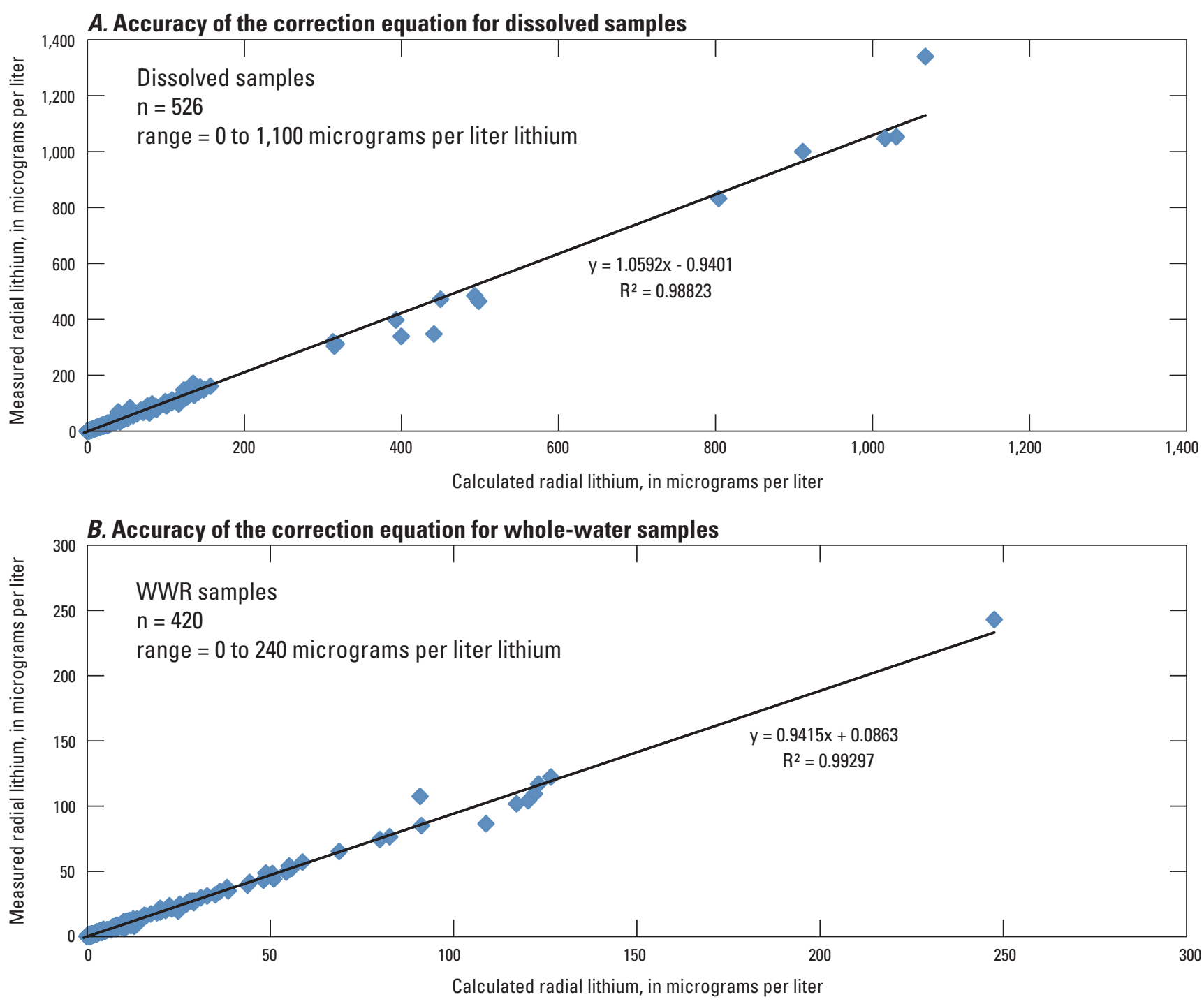

Figure B1. Accuracy of correction equation for $(A)$ dissolved and $(B)$ whole-water samples, Dixie Valley, west-central Nevada. 


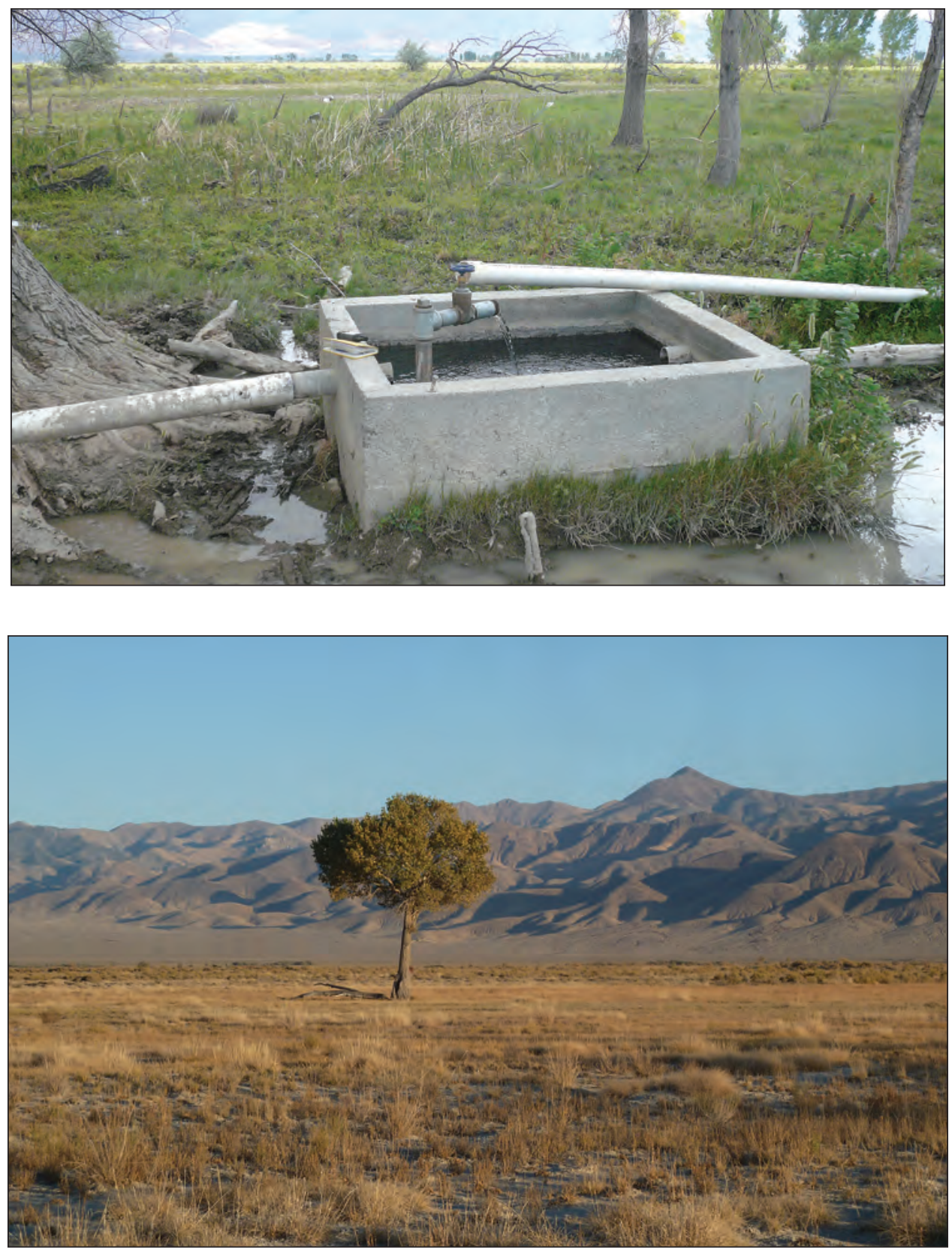

Top: Flowing artesian well, site 44, in the historic Dixie Valley settlement, viewed toward the north. Photograph taken by Chris Mahannah, Mahannah and Associates, LLC, June 9, 2009.

Bottom: Eastern part of historic Dixie Valley settlement as viewed to the east toward the Clan Alpine Mountains. Photograph taken by Jena Huntington, U.S. Geological Survey, October 26, 2011.

Publishing support provided by the U.S. Geological Survey

Publishing Network, Tacoma Publishing Service Center

For more information concerning the research in this report, contact the Nevada Water Science Center U.S. Geological Survey 2730 N. Deer Run Rd. Carson City, NV 89701 http://nevada.usgs.gov/water/ 


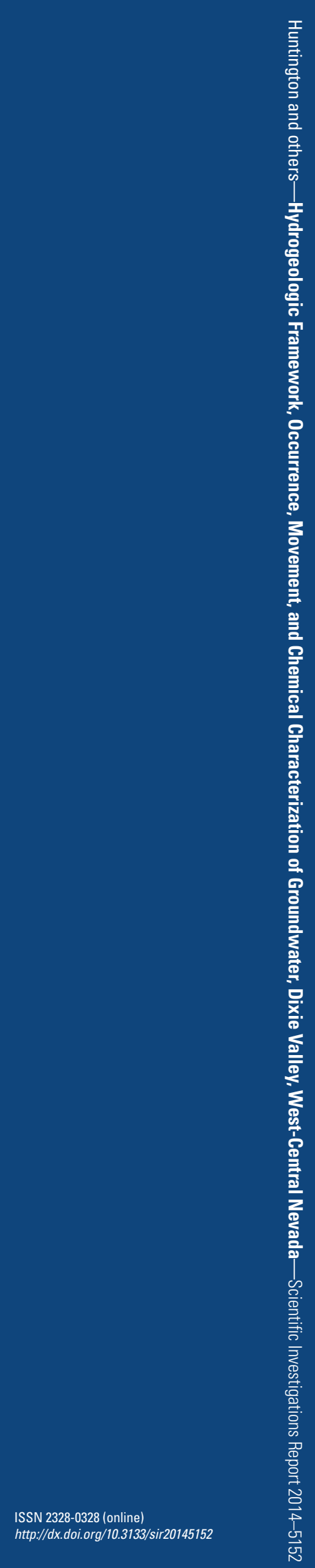

